SANDRA CAMPOS RODRIGUES

\title{
EFEITOS DA PINEALECTOMIA E DO BLOQUEIO DA SINALIZAÇÃO \\ DO RECEPTOR DE GLICOCORTICÓIDES SOBRE AS FUNÇÕES METABÓLICAS E INFLAMATÓRIAS HEPÁTICAS
}

\begin{abstract}
Tese apresentada ao Programa de Pós Graduação em Fisiologia Humana do Instituto de Ciências Biomédicas da Universidade de São Paulo, para obtenção de Título de Doutor em Ciências.
\end{abstract}


SANDRA CAMPOS RODRIGUES

\section{EFEITOS DA PINEALECTOMIA E DO BLOQUEIO DA SINALIZAÇÃO DO RECEPTOR DE GLICOCORTICÓIDES SOBRE AS FUNÇÕES METABÓLICAS E INFLAMATÓRIAS HEPÁTICAS}

Tese apresentada ao Programa de Pós Graduação em Fisiologia Humana do Instituto de Ciências Biomédicas da Universidade de São Paulo, para obtenção de Título de Doutor em Ciências.

Área de Concentração: Fisiologia Humana

Orientadora: Prof. ${ }^{a}$ Dr. ${ }^{-}$Silvana A. Bordin da Silva

Versão original 
DADOS DE CATALOGAÇÃO NA PUBLICAÇÃO (CIP)

Serviço de Biblioteca e Informação Biomédica do

Instituto de Ciências Biomédicas da Universidade de São Paulo

reprodução não autorizada pelo autor

\section{Rodrigues, Sandra Campos.}

Efeitos da pinealectomia e do bloqueio da sinalização do receptor de glicocorticoides sobre as funções metabólicas e inflamatórias hepáticas / Sandra Campos Rodrigues. -- São Paulo, 2015.

Orientador: Profa. Dra. Silvana Auxiliadora Bordin da Silva.

Tese (Doutorado) - Universidade de São Paulo. Instituto de Ciências Biomédicas. Departamento de Fisiologia e Biofísica. Área de concentração: Fisiologia Humana. Linha de pesquisa: Metabolismo energético/Bioquímica/Fisiologia de órgãos e sistemas.

Versão do título para o inglês: Effects of pinealectomy and blockade of signaling by glucocorticoid receptor on the matabolic and inflammatory liver functions.

1. Fígado 2. Metabolismo energético 3. Inflamação 4

Glicocorticóides 5. Melatonina I. Silva, Profa. Dra. Silvana

Auxiliadora Bordin da II. Universidade de São Paulo. Instituto de

Ciências Biomédicas. Programa de Pós-Graduação em Fisiologia Humana III. Título. 
UNIVERSIDADE DE SÃO PAULO

INSTITUTO DE CIÊNCIAS BIOMÉDICAS

\begin{abstract}
Candidato(a): $\quad$ Sandra Campos Rodrigues.
Título da Tese: $\quad$ Efeitos da pinealectomia e do bloqueio da sinalização do receptor de glicocorticoides sobre as funções metabólicas e inflamatórias hepáticas.
\end{abstract}

Orientador(a): $\quad$ Profa. Dra. Silvana Auxiliadora Bordin da Silva.

A Comissão Julgadora dos trabalhos de Defesa da Tese de Doutorado, em sessão

pública realizada a

( ) Aprovado(a)

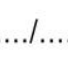

( ) Reprovado(a)

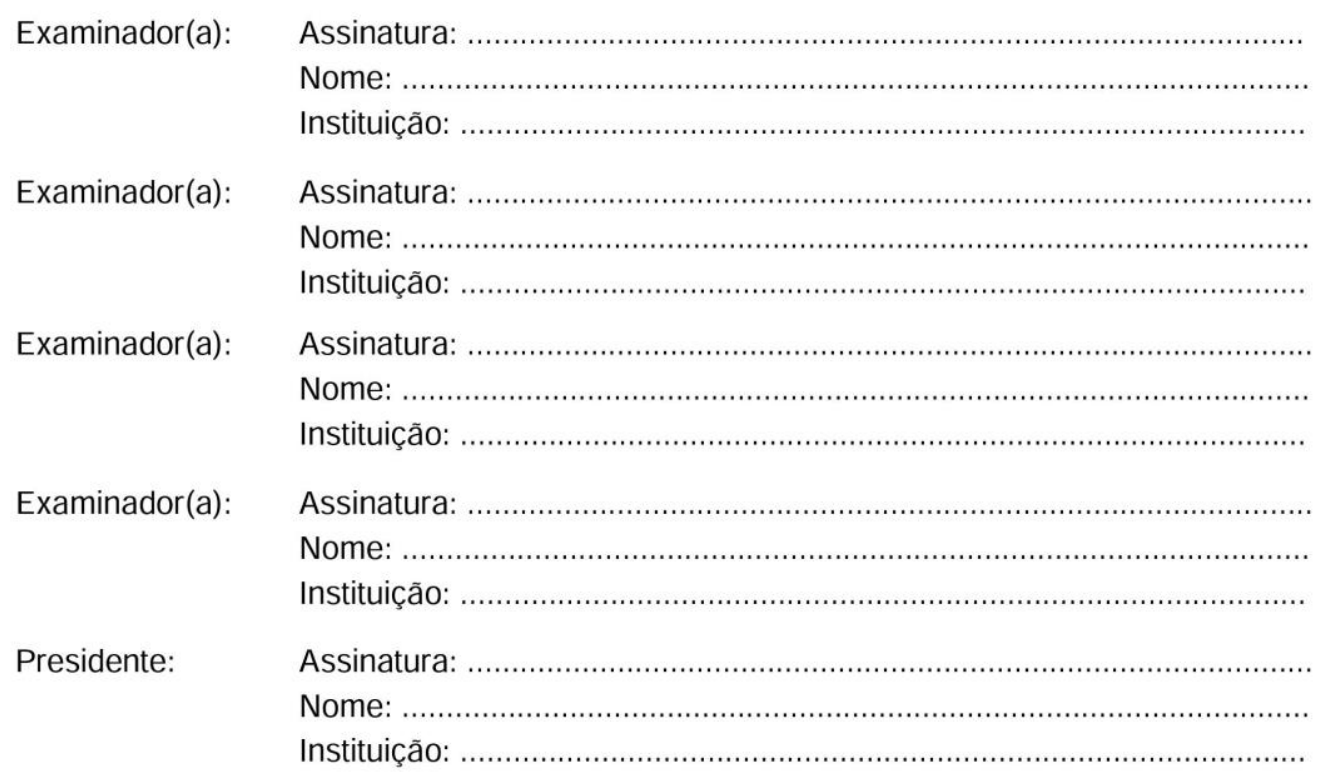




\section{Certificado}

Certificamos que o protocolo registrado sob $n^{0} \mathbf{1 0 3}$ nas fls. 109 do livro 02 para uso de animais em experimentação, sob a responsabilidade do Prof(a) $\operatorname{Dr}(\mathrm{a})$ ) Silvana Auxiliadora Bordin da Silva, Coordenador(a) da Linha de pesquisa "Participação dos glicocorticoides na regulação circadiana do metabolismo energético hepático" do qual participam o(s) aluno(s) Sandra Campos Rodrigues e a pesquisadora Fernanda Gaspar do Amaral, está de acordo com os Princípios Éticos de Experimentação Animal adotado pela Sociedade Brasileira de Ciência de Animais de Laboratório (SBCAL) e foi aprovado pela COMISSÃO DE ÉTICA NO USO DE ANIMAIS (CEUA) em 29.08.2011, com validade de 3 anos.

São Paulo, 30 de agosto de 2011.
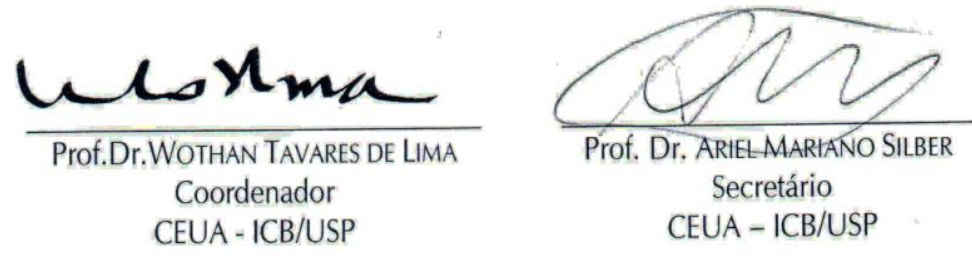


\section{OS.CEUA. 068.14}

Şo Paulo, 08 de setembro de 2014

REF.: Protocolo $n^{\circ}$ 103/11.

"Participagáo dos glicoconticoides na regulaça circadiana do merabolismo energetico hepárico"

Prezada Professora,

Informo que a sua licença para uso de animais em experimentaçăo, constante Do protocolo em epigrafe, fol prorrogada atk 29.08.2017

Reitero que havendo alteraçăo de metodologia $e$ inserça de novos aluncs ao projeto de pesquisa vinculado à referida licença a CEUA/ICB deverá ser informadta.

Cordialmene,

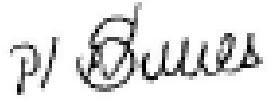

Prof. Dr. Wothan TAvares de LIMa

Coordemados - CEUA-ICB/ /USP

Ilma.Sra.

Profar Dra. Silvana Auxiliadora Bordin da Silva

Departamento de Fisiologia e Biofisica

Instituto de Cièncias Biomédicas - USP 
À realização de um sonho. 


\section{AGRADECIMENTOS}

Ao governo do Estado de São Paulo e à prefeitura de Ribeirão Preto que financiaram toda minha educação formal e acadêmica. Foi graças à educação pública brasileira, especialmente a oferecida pelo meu estado natal, que tornou possível que eu realizasse meu sonho de me pós- graduar com excelente qualidade.

À Fundação de Amparo a Pesquisa do Estado de São Paulo (FAPESP), pelo prestígio e apoio financeiro proporcionados em todas as minhas iniciativas de pesquisa, da Iniciação Científica ao Doutorado. A FAPESP reconheceu meu empenho ao longo do meu caminho profissional e me proporcionou boas experiências e realizações. Agradeço à FAPESP por ter apoiado minha formação científica e acadêmica.

Aos meus pais, Eliziário Rodrigues e Celma Campos que me deram todo apoio necessário ao longo desses mais de 22 anos por escolas e universidades. Sou grata por terem me incentivado intelectualmente desde a infância e por terem me impelido a aprender. Muitíssimo obrigada por tudo, meus méritos são por causa das chances que vocês me deram.

À Adriano Zager, pelo apoio emocional, paciência e companheirismo nos momentos difíceis. Obrigada pela ajuda experimental e pela feliz oportunidade de colaboração acadêmica com você. Sua participação nesta tese e na minha formação foi importantíssima.

À Lucas Pantaleão, que durante a maior parte do meu doutorado foi meu braço direito experimental, sempre uma divertida companhia. Sua presença sempre certa e boa vontade para o trabalho foi fundamental na maior parte dos resultados obtidos nesta tese.

Agradeço aos meus amigos do departamento Katherine Veras, Flávia Azevedo, Gabriela Moreira, Vitor Felitti e Caio Jordão, pela troca de idéias, pela ajuda em experimentos e por terem sido um sopro de alívio, conforto e diversão no ICB, eu adoro todos os cafés com quitutes com vocês.

À Prof. a Silvana Bordin, pela orientação e pela pesquisa, por ter me aceito em seu grupo e me oferecido condições de trabalho e sucesso; pelo exemplo de 
inteligência, pela liberdade e confiança na condução da minha pesquisa e pelas valiosas publicações.

Ao Prof. Rui Curi que me recebeu muitíssimo bem em seu laboratório, oferecendo-me apoio, aconselhamento e o privilégio de compartilhar de sua presença, um exemplo de grande docente e pesquisador.

Ao Centro de Facilidades de Apoio à Pesquisa (CEFAP/ USP), que graças aos equipamentos e serviços disponíveis, proporcionou-me uma valiosa análise experimental.

Aos secretários da pós-graduação da Fisiologia e Biofísica, José Maria e Paloma, por serem funcionários dedicados, preocupados, interessados e competentes, sem os quais eu teria tido muito mais dificuldades durante meu curso de pós-graduação.

Aos professores Carla Oliveira e José Cipolla pelas facilidades em seus laboratórios.

À Chayra Cheade, Danilo Ferreira, Juliana Faria, Gilson Murata, Julieta Scialfa e Fernanda Amaral pelo auxílio experimental e técnico. 
"Tudo passa - sofrimento, dor, sangue, fome, peste. A espada também passará, mas as estrelas ainda permanecerão quando as sombras de nossa presença e nossos feitos se tiverem desvanecido da Terra. Não há homem que não saiba disso. Por que então não voltar nossos olhos para as estrelas?"

MIKHAIL BULGAKOV, O exército branco. 


\section{RESUMO}

RODRIGUES, S. C. Efeitos da pinealectomia e do bloqueio da sinalização do receptor de glicocorticóides sobre as funções metabólicas e inflamatórias hepáticas. 2015. $107 \mathrm{f}$. Tese (Doutorado em Fisiologia Humana) - Instituto de Ciências Biomédicas, Universidade de São Paulo, São Paulo, 2015.

Os ritmos biológicos circadianos garantem a relação temporal entre os seres e o ambiente. A regulação metabólica se relaciona à ritmicidade dos ciclos de claroescuro, com importância das ações da melatonina e dos glicocorticóides no fígado. Investigamos o papel dos glicocorticóides no ajuste metabólico mediado pela secreção rítmica de melatonina e no contexto inflamatório hepático. Ratos Wistar machos pinealectomizados tratados ou não com RU 486 tiveram o padrão circadiano circulante de corticosterona, insulina e glicose aferido ao longo de 8 ZTs. No ZT10, analisou-se a expressão de RNAm e protéica envolvidas em ações metabólicas e inflamatórias. Os resultados dos testes in vivo de tolerância à glicose e ao piruvato, secreção de insulina estimulada por glicose (GSIS) e avaliação no fígado da p-AKT estimulada no ZT 10, em conjunto com as alterações na composição corpórea, conteúdo de glicogênio e histologia do fígado, apontam maior influência da sinalização por corticosterona no metabolismo da glicose e resposta insulínica hepática, assim como correlação dos efeitos da melatonina e dos glicocorticóides no metabolismo energético e na modulação da resposta inflamatória hepática.

Palavras-chave: Fígado. Metabolismo energético. Inflamação. Glicocorticóides. Melatonina. 


\begin{abstract}
RODRIGUES, S. C. Effects of pinealectomy and blockade of signaling by glucocorticoid receptor on the metabolic and inflammatory liver fuctions. 2015. 107 p. Ph. D. thesis (Human Physiology) - Instituto de Ciências Biomédicas, Universidade de São Paulo, São Paulo, 2015.

Circadian biological rhythms guarantee the temporal relationship between living beings and the environment. Metabolic regulation relates to the rhythm to the lightdark cycle, with importance of the actions of melatonin and glucocorticoids in the liver. We investigated the role of glucocorticoids in the metabolic adjustment mediated by rhythmic secretion of melatonin and in the liver inflammatory context. Male Wistar rats pinealectomized treated or not with RU 486 had the circadian levels of circulating corticosterone, insulin and glucose measured along 8 ZTs. At ZT 10, we analyzed mRNA and protein expression related to metabolic and inflammatory actions. Our results from in vivo tests to glucose and pyruvate tolerance, glucose stimulated insulin secretion (GSIS) and evaluation in liver of p-AKT stimulated at ZT10, along with the changes on body composition, glycogen content and liver histology, indicate influence of corticosterone signaling on glucose metabolism and insulin response in liver, as well as correlation of melatonin and glucocorticoids effects in energy metabolism and in the modulation of inflammatory response in liver.
\end{abstract}

Keywords: Liver. Energy metabolism. Inflammation. Glucocorticoids. Melatonin. 


\section{LISTA DE ABREVIATURAS E SIGLAS}

$\mu$ - micro

$\mu \mathrm{m}$ - micrometro

$11 \beta$ HSD 1- $11 \beta$ hidroxidesidrogenase do tipo 1

ACC- acetil-coA-carboxiquinase

ACTH- hormônio adrenocorticotrópico

AGE- produto final de glicação avançada

AKT- proteína quinase $B$

APM- agente patogênico molecular

ApoB- apo-lipo-proteína B

ATF- fator ativador de transcrição

BiP- proteína chaperone de ligação

BMP9- proteína morfogênica óssea

CD36- translocase de ácidos graxos

cFLIP- celullar caspase-8-like inhibitory protein

ChIP assay- ensaio de imunoprecipitação de cromatina

CHOP- CCAAT/enhancer-binding

protein-homologous protein

cm- centímetros

$\mathrm{CRH}$ - corticotropina

Cyld- cylindromatosis

Dgat- diacilglicerol acetiltransferase

DHGNA- doença hepática gordurosa não alcoólica

$\mathrm{dL}$ - decilitro

DUSP1- fosfatase 1 de dupla especificidade

ENA- esteatose não alcoólica

EUA- Estados Unidos da América

Foxo1-forkhead box-other 1

g-gramas

G6P-glicose-6-fosfato
G6pase/G6pc- glicose 6 fosfatase

GADD- growth arrest and DNA damage-inducible protein

Gck- glicoquinase

GLUT- transportador de glicose

GR- receptor de glicocortóides

Gys2- glicogênio sintase 2

h- horas

H6pd- hexose-6-fosfato desidrogenase HISS- hepatic insulin sensitizing substance

HNF- hepatocyte nuiclear fator

ICB - instituto de ciências biomédicas

IKK- IkB quinase

IL- interleucina

IL1 $R 1$ - receptor 1 de interleucina 1

IL1 RN- antagonista do receptor de IL1

iNOS- isoforma induzível de NOS

ip.- intraperitoneal

IRS- substrato do receptor de insulina JNK- c-Jun N-terminal kinase

$\mathrm{kg}$ - quilograma

$\mathrm{Km}$ - constante de Michaelis- Menten

LOX-1 - lectin like ox-LDL receptor 1

$L X R$ - receptores hepáticos $X$

M- molar

Me- enzima málica

mg- miligrama

MHC- complexo de

histocompatibilidade principal

min- minutos

MKK- mitogen activated protein kinase kinase 
MKP- proteína quinase de ação mitogênica

$\mathrm{mL}$ - mililitro

mM- milimolar

mm-milímetro

mTOR- mammalian target of rapamycin

Mttp- microsomal triglyceride transfer protein

NF-kB- fator nuclear kappa B

ng- nanogramas

nm- nanomêtros

NO- óxido nítrico

NOS- sintase de óxido nítrico

nPKC- proteína quinase $\mathrm{C}$ original

NSQ- núcleo supraquiasmático

hipotalâmicos

P53- proteína 53

PCK-gene da fosfoenolpiruvato

carboxiquinase

PEPCK- fosfoenolpiruvato

carboxiquinase

PGC- peroxisome proliferator activated receptor gamma.

PHG- produção hepática de glicose

PI3K- fosfatidil inositol 3 quinase

PKC- proteína quinase $\mathrm{C}$

PPI- fosfatase protéica 1

RAGE- receptor de produtos finais da glicação avançada

RAPTOR- regulatory associated protein of $M T O R$

RE- retículo endoplasmático
RHI- resistência hepática à insulina RICTOR- rapamycin insensitive companion of mTOR

RIP- receptor interacting protein kinase

RNA- ácido desoxirribonucleico

RNAm- RNA mensageiro

ROS- espécies reativas de oxigênio

Rpl - proteína ribosomal

rpm- rotação por minuto

$s$ - segundos

sec- seconds

Sec22b- vesicle trafficking protein homolog $B$

Socs3- suppressor of cytokine signaling 3

SOD- superóxido dismutase

STAT- transdutor de sinal e ativador de transcrição

SYK- spleen tirosina quinase

TAK1- mitogen activated protein kinase kinase kinase 7

TGF $\beta$ - fator de crescimento transformador $\beta$

TLR- receptor do tipo Toll

TNF- fator de necrose tumoral

TRADD- TNF R1 associated death domain protein

TRAF- TNF receptor associated factor 1

TRB3- tribble 3 protein

UA- unidades arbitrárias

vs.- versus

ZT- zeitgeber time 


\section{SUMÁRIO}

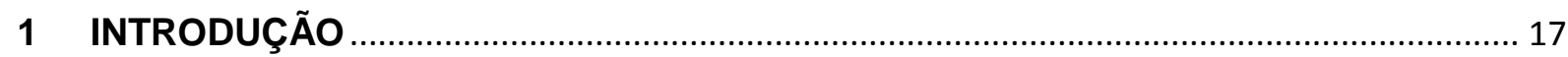

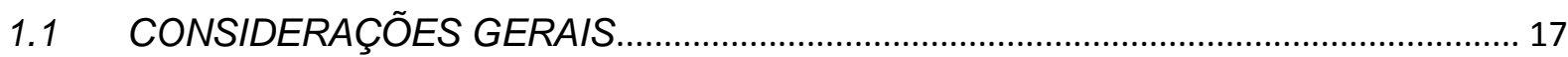

1.2 CONTROLE DO METABOLISMO ENERGÉTICO ..................................................... 20

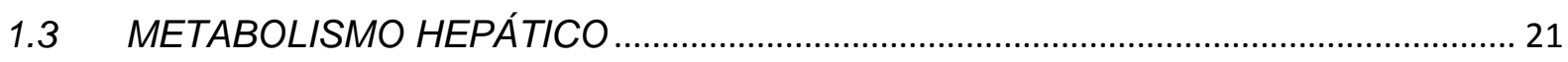

1.4 GLICOCORTICÓIDES E O METABOLISMO ENERGÉTICO ...................................... 25

1.5 REGULAÇÃO CIRCADIANA DO METABOLISMO ENERGÉTICO …........................ 25

1.6 HOMEOSTASIA GLICÊMICA, ESTRESSE OXIDATIVO E INFLAMAÇÃO HEPÁTICA

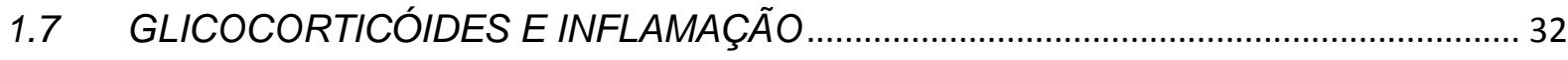

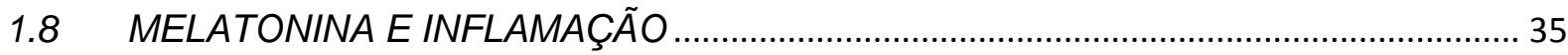

2 OBJETIVO

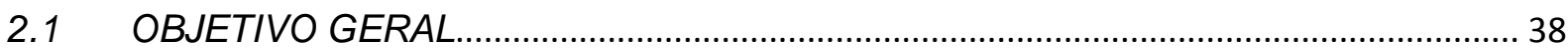

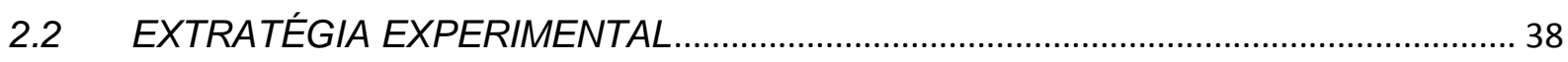

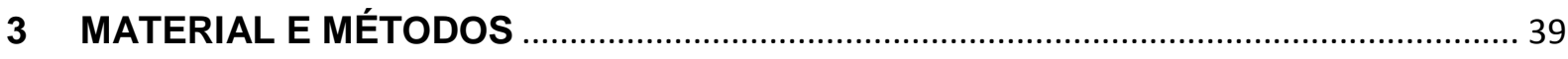

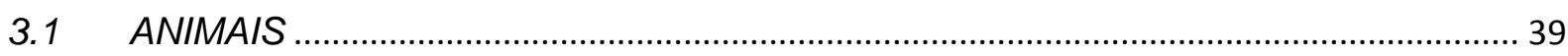

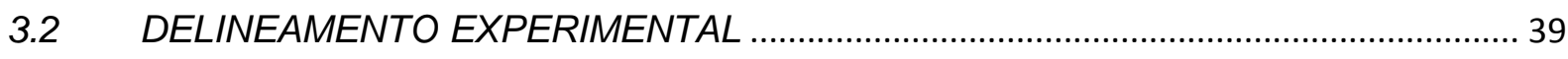

3.2.1 PERÍODOS DE INTERESSE EXPERIMENTAL ...................................................... 39

3.2.2 GRUPOS EXPERIMENTAIS E TRATAMENTO FARMACOLÓGICO ........................ 41

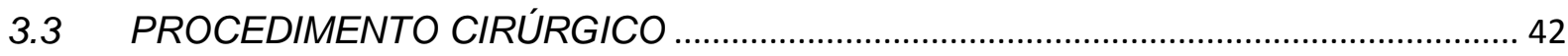

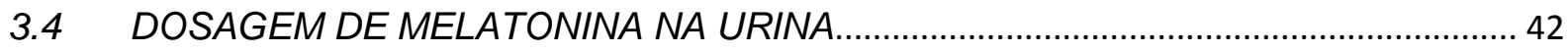

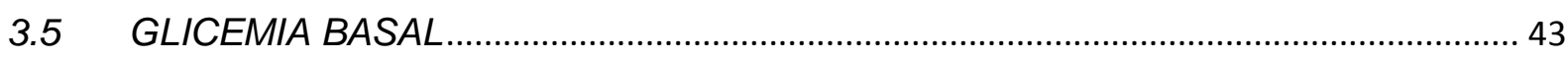

3.6 RADIOIMUNOENSAIO PARA AFERÊNCIA DE INSULINEMIA .................................... 43

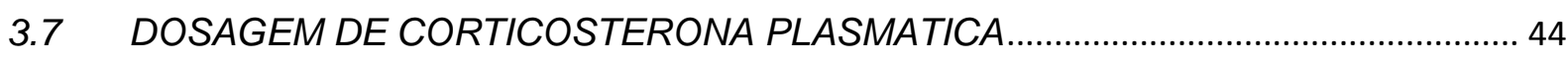

3.8 MORFOMETRIA POR IMAGEAMENTO IN VIVO E PESAGEM................................. 44

3.9 TESTE DE TOLERÂNCIA INTRAPERITONEAL À GLICOSE (ip.GTT) ...................... 44

3.10 TESTE DE TOLERÂNCIA INTRAPERITONEAL AO PIRUVATO (ip PTT)................. 45 
3.11 ANÁLISES DE SECREÇÃO ESTÁTICA DE INSULINA ESTIMULADA POR

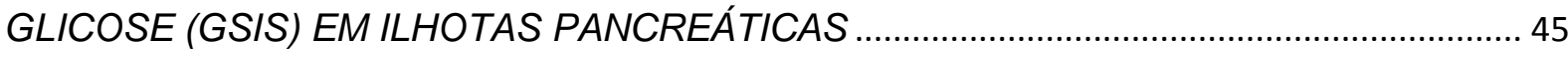

3.11.1 EXTRAÇÃO DE ILHOTAS PANCREÁTICAS ............................................................... 45

3.11.2 AVALIAÇÃO DA SECREÇÃO ESTÁTICA DE INSULINA …………………………….... 46

3.12 ANÁLISES DE LIPÍDEOS CIRCULANTES ................................................................. 46

3.13 EXTRAÇÃO PROTÉICA E IMUNOBLOTTING DO FÍGADO ........................................ 46

3.14 IMUNOBLOTTING APÓS ESTÍMULO COM INSULINA ……………………….......... 47

3.15 TRANSCRIÇÃO REVERSA E PCR TEMPO REAL .................................................... 48

3.15.1 EXTRAÇÃO DE RNA TOTAL DO FÍGADO ............................................................ 48

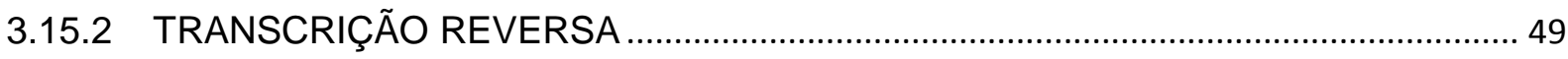

3.15.3 PCR EM TEMPO REAL .......................................................................................... 49

3.16 ANÁLISES HISTOLÓGICAS HEPÁTICAS................................................................. 51

3.16.1 HISTOLOGIA ………………………………………………………….... 51

3.16.2 MORFOMETRIA CELULAR …………………………………………………….... 52

3.17 ESTIMATIVA DO CONTEÚDO DE GLICOGÊNIO HEPÁTICO.....................................53

3.18 ANÁLISE ESTATÍSTICA …………………………………………………..... 53

4 RESULTADOS

4.1 EFEITOS DA PINEALECTOMINA SOBRE NÍVEIS DE MELATONINA...................... 55

4.2 EFEITOS DA PINEALECTOMINA SOBRE NÍVEIS GLICÊMICOS E HORMONAIS. 55

4.3 EFEITOS DA RETIRADA DA GLÂNDULA PINEAL E DO BLOQUEIO FARMACOLÓGICO DA SINALIZAÇÃO DO RECEPTOR DE GLICOCORTICÓIDES SOBRE O METABOLISMO ENERGÉTICO NO ZT 10 …………………………………………...... 57

4.3.1 EFEITOS DA PINEALECTOMINA E DO BLOQUEIO FARMACOLÓGICO DA SINALIZAÇÃO DO RECEPTOR DE GLICOCORTICÓIDES SOBRE NÍVEIS GLICÊMICO E

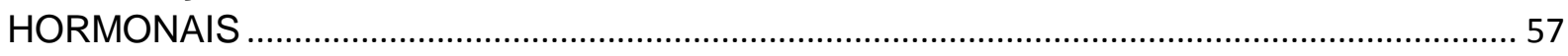

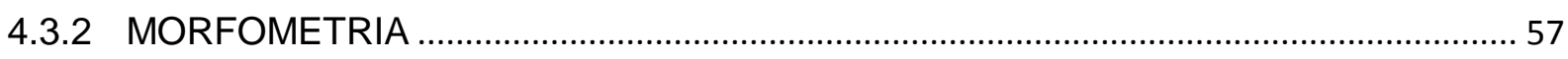

4.3.3 TESTES FUNCIONAIS IN VIVO DE TOLERÂNCIA E SENSIBILIDADE À GLICOSE E

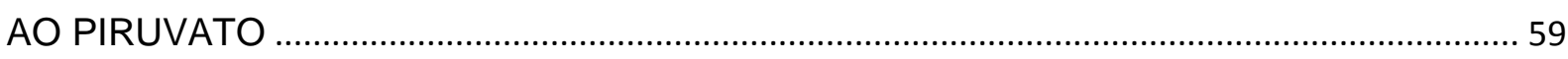

4.3.4 ANÁLISES DE SECREÇÃO ESTÁTICA DE INSULINA EM ILHOTAS PANCREÁTICAS. 
4.3.6 RESPOSTA DE FOSFORILAÇÃO DA AKT HEPÁTICA APÓS ESTÍMULO COM INSULINA

4.3.7 ALTERAÇÃO DOS NÍVEIS PROTÉICOS E DE TRANSCRIÇÃO DE RNAm DE PROTEÍNAS HEPÁTICAS RELACIONADAS À SINALIZAÇÃO DO RECEPTOR DE GLICOCORTICÓIDES

4.3.8 CONTEÚDOS RELATIVOS DE RNAm HEPÁTICO PARA GENES ENVOLVIDOS NO METABOLISMO ENERGÉTICO.

4.3.9 CONTEÚDOS RELATIVOS DE RNAm HEPÁTICO PARA GENES ENVOLVIDOS NO

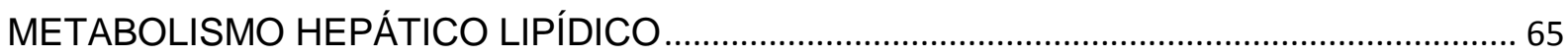

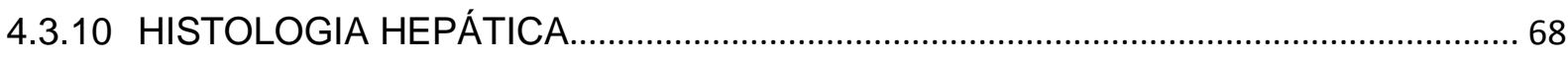

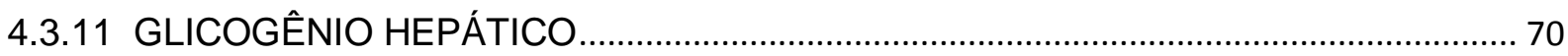

4.4 EFEITOS DA RETIRADA DA GLÂNDULA PINEAL E DO BLOQUEIO FARMACOLÓGICO DA SINALIZAÇÃO DO RECEPTOR DE GLICOCORTICÓIDES SOBRE

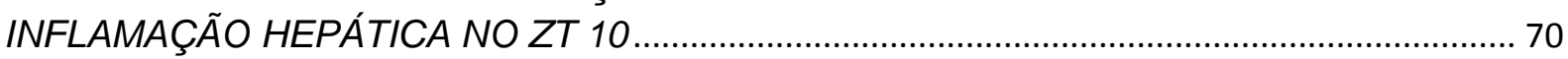

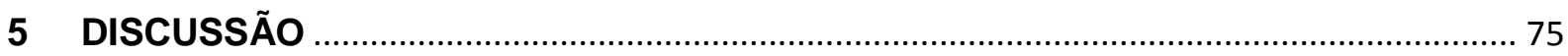

5.1 EFEITOS DA RETIRADA DA GLÂNDULA PINEAL E DO BLOQUEIO FARMACOLÓGICO DA SINALIZAÇÃO DO RECEPTOR DE GLICOCORTICÓIDES SOBRE O METABOLISMO ENERGÉTICO HEPÁTICO. 75

5.2 EFEITOS DA RETIRADA DA GLÂNDULA PINEAL E DO BLOQUEIO FARMACOLÓGICO DA SINALIZAÇÃO DO RECEPTOR DE GLICOCORTICÓIDES SOBRE INFLAMAÇÃO HEPÁTICA.

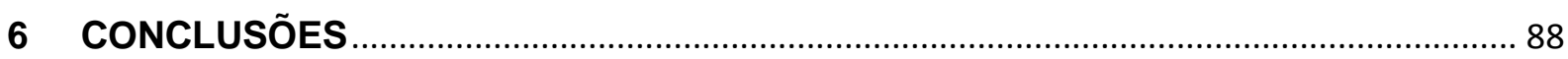

6.1 METABOLISMO HEPÁTICO ENERGÉTICO............................................................... 88

6.2 INFLAMAÇÃO HEPÁTICA ……………………………………………………... 88

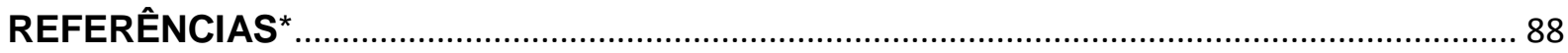




\section{INTRODUÇÃO}

\subsection{CONSIDERAÇÕES GERAIS}

Os ritmos biológicos circadianos constituem uma estratégia adaptativa que garante a relação temporal entre os seres vivos e seu meio ambiente, em geral sincronizada pelo ciclo claro-escuro do dia e da noite. Para isso, a temporização circadiana organiza os processos fisiológicos e comportamentais para que diferentes órgãos e sistemas operem de forma adaptada à fase do dia, com variações qualitativas e quantitativas que garantem a perfeita relação temporal entre os seres vivos e seu ambiente e, por extensão, a sobrevivência individual e da espécie. Assim, a sinalização do ciclo claro-escuro ao organismo é fundamental para a regulação da maioria das funções inerentes à sobrevivência de um animal, posto que modifica padrões hormonais, metabólicos e comportamentais do indivíduo. Diversas funções do organismo, como a reprodução, freqüência cardíaca, função renal, motilidade intestinal, ciclos de sono-vigília, fenômenos de torpor e hibernação, dentre outros, apresentam regulação cíclica (BOYCE; BARRIBALL, 2010).

Sabe-se que processos rítmicos associados ao balanço energético e suas alterações metabólicas resultantes variam sazonalmente de acordo com a disponibilidade de alimentos, ciclos reprodutivos sazonais, migratórios, etc. (SCOTT; GRANT, 2006). Uma das estratégias mais importantes, filogeneticamente selecionada nos vertebrados para garantir a sincronização dos processos rítmicos fisiológicos e comportamentais com o meio ambiente, foi a de acoplar independentemente das características de atividade da espécie - a secreção de melatonina pela glândula pineal ao período da noite, de forma dependente da duração deste período. Dessa forma, para os vertebrados, a produção de melatonina adquire a característica funcional de representar e sinalizar para o meio interno (pela sua maior ou menor concentração plasmática) se é noite ou dia no meio exterior, além de sinalizar, por meio da duração do episódio secretório, a duração da noite externa e a estação do ano (REITER, 1993).

A organização do sistema de temporização circadiana depende de um oscilador central, localizado nos núcleos supraquiasmáticos hipotalâmicos (NSQ), que através de sinais neurais e humorais sinaliza à pineal o grau de luminosidade 
ambiental e também controla os relógios periféricos localizados em todos os órgãos e tecidos efetores.

Vários fatores participam da sinalização claro-escuro, porém os mais evidentes sob o ponto de vista endócrino são, além da melatonina na fase de escuro, a ação dos hormônios corticosterona e cortisol na fase de claro, os glicocorticóides ativos na maioria dos mamíferos e na espécie humana, respectivamente.

Os hormônios glicocorticóides são esteróides, produzidos a partir do colesterol, na zona fasciculada e reticular do córtex das glândulas adrenais. O colesterol provém de ésteres de colesterol armazenados na célula, e que provem de lipoproteínas de baixa densidade (LDL) que circulam no sangue, ou da síntese de novo a partir do acetato nas glândulas adrenais (ORTH; KOVACS, 1998). Exercem um papel importante em vários órgãos e sistemas, participando da regulação fisiológica e da adaptação às situações de estresse.

A concentração de glicocorticóide circulante é regulada através do ajuste do eixo hipotalâmico-hipofisário-adrenal, influenciado por fatores como o ritmo circadiano (BRADBURY et al., 1991), estresse (MAKINO; HASHIMOTO; GOLD, 2002) e o feedback negativo (LAUGERO, 2004); este último fator é exercido pelo próprio glicocorticóide, agindo sobre os receptores glicocorticóides (GR), presentes no hipotálamo e na hipófise.

Devido à sua natureza química, os glicocorticóides circulam ligados a proteínas plasmáticas e se difundem através da membrana plasmática da célula alvo, ligandose aos receptores de glicocorticóides no citoplasma. Os complexos hormônioreceptor formados são translocados ao núcleo onde se ligam a regiões específicas do DNA, os elementos de resposta aos glicocorticóides (Figura 1). Essa ligação estimula ou inibe eventos de transcrição do gene-alvo, dando-se através das flutuações nos níveis protéicos resultantes desse processo os efeitos biológicos dos glicocorticóides (CONSIDINE, 2005). 

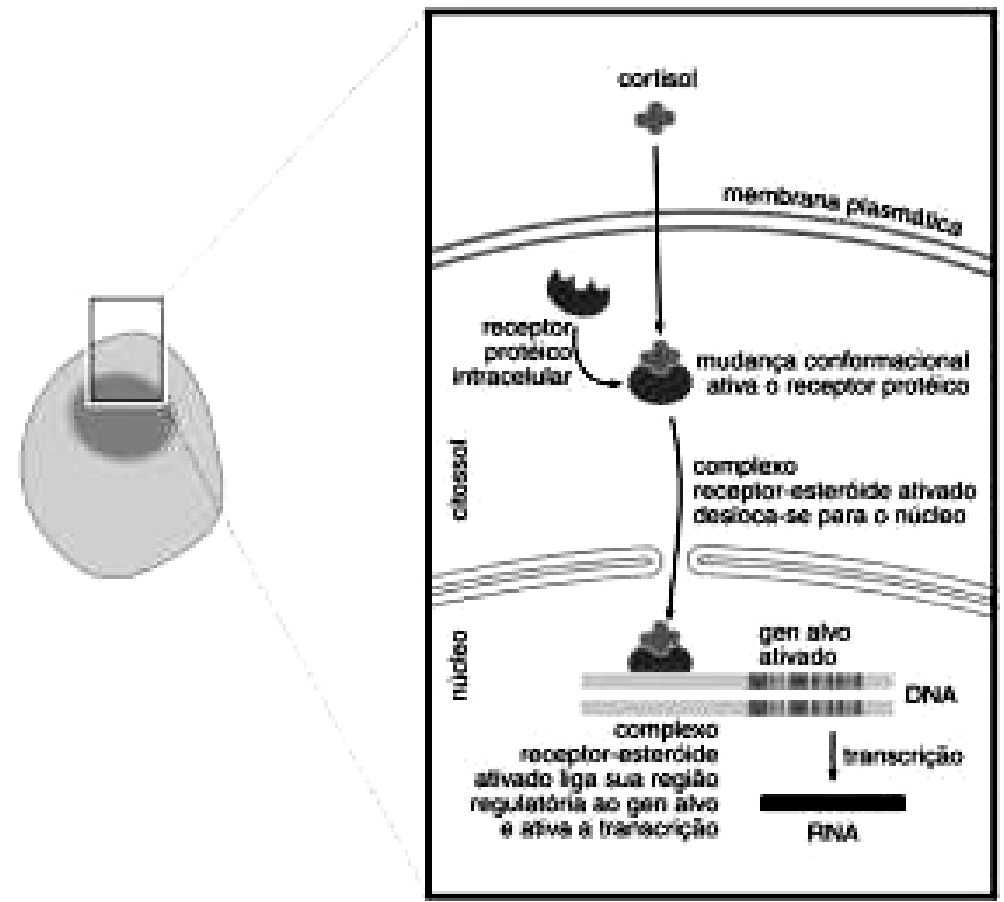

Figura 1: O cortisol, produzido pelas glândulas supra-renais humanas, é um sinalizador hidrofóbico que forma um complexo receptor ligante, entrando no núcleo, onde vai ativar a transcrição de genes.

Farmacologicamente, a sinalização dos glicocorticóides pode ser bloqueada com o fármaco RU 486 ou mifepristona (Figura 2). O RU 486 é um antagonista de receptor de progesterona que, em altas concentrações, provoca um bloqueio do GR (FLESERIU et al., 2012), mas não dos receptores de mineralocorticóides (CASTINETTI; CONTE- DEVOLX; BRUE, 2010).

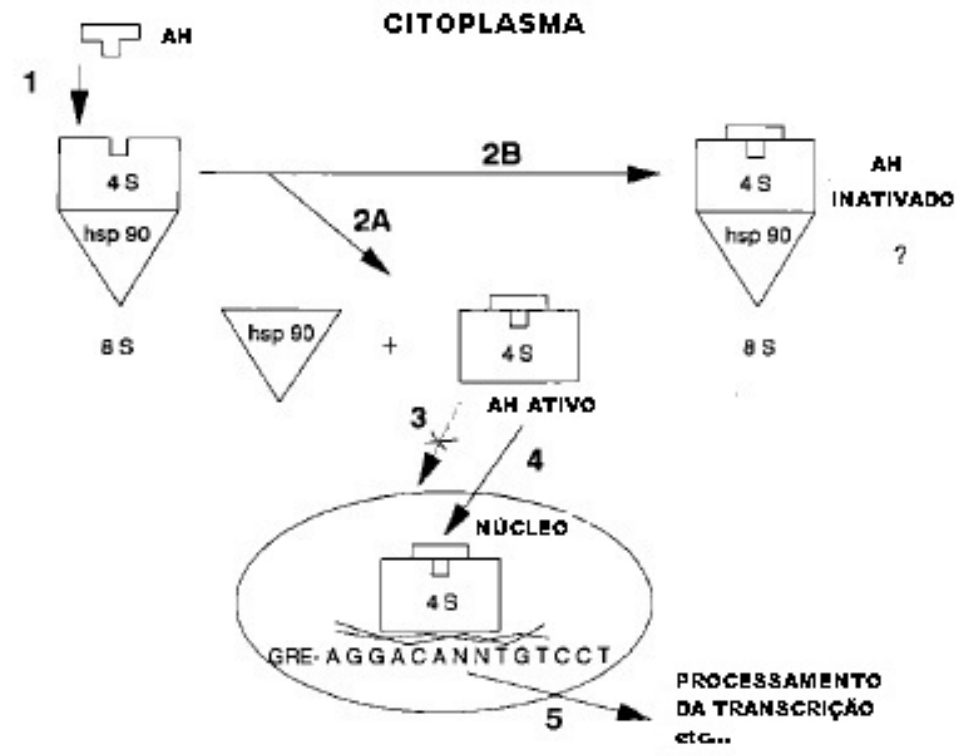

Figura 2: Mecanismo de ação de um anti-hormônio. AH: anti-hormônio. Modificada de MAO; REGELSON; KALIMI, 1992. 
Os glicocorticóides são sinalizadores do início do período diurno em animais cujo período ativo é o dia (inclusive em humanos) e de importante participação no início do ciclo de vigília, sendo bem conhecido o pico de cortisol matinal em humanos (WEITZMAN et al., 1971). Já em animais cujo período ativo é o noturno, o que se nota é a existência do pico de glicocorticóide no início da noite, de modo compatível aos hábitos noturnos da espécie (FULLER; GOOLEY; SAPER, 2006).

Nos mamíferos, a pineal não apresenta característica de órgão fotoreceptor como em outras espécies animais em que a luz inibe diretamente a produção de melatonina. O controle dos ciclos ambientais de iluminação sobre a produção de melatonina nos mamíferos se dá de forma indireta, por projeções retinianas para estruturas diencefálicas e destas para os neurônios pré-ganglionares que, através da inervação simpática periférica, inervam a glândula pineal (BARTOL et al., 1997; CIPOLLA-NETO et al., 1995; CIPOLLA-NETO et al., 1999; RIBEIRO-BARBOSA et al., 1999).

Dessa forma, a melatonina pode regular e sincronizar, circadiana e sazonalmente, processos fisiológicos vitais como atividade e repouso, sono e vigília, processos reprodutivos, secreções hormonais e a aquisição, armazenamento, consumo e preservação de energia e, conseqüentemente, todos os processos envolvidos na regulação do metabolismo energético.

\subsection{CONTROLE DO METABOLISMO ENERGÉTICO}

Ao longo do desenvolvimento evolutivo, podemos observar em diversos animais plesiomórficos em relação aos mamíferos, incomum disposição anatômica dos órgãos dos sistemas fisiológicos. Por exemplo, em crustáceos, o hepatopâncreas concentra funções de pâncreas endócrino, pâncreas exócrino e fígado num só órgão.

Quanto aos órgãos envolvidos no controle do metabolismo, é possível verificar de maneira clara a intersecção entre função e disposição anatômica dos órgãos (com circulação associada) em várias espécies animais, inclusive no humano, em que a circulação porta-hepática permite íntima e privilegiada sinalização entre sistema digestivo e glândulas associadas. Em mamíferos, como nesta tese estudados, a concentração no pâncreas de funções exócrinas (no sistema 
digestório) e endócrinas demonstra quão regulada precisa ser a secreção de hormônios controladores do metabolismo de acordo com o tipo e quantidade de alimentos ingerida. De modo geral, em todos os órgãos animais, a fina comunicação entre o tecido que os perfaz e os sistemas circulatório e nervoso locais permitem a adequação entre a função do órgão ao status sistêmico do organismo.

A insulina, principal hormônio pancreático, tem diversas ações bem conhecidas sob o metabolismo hepático de mamíferos, estimulando a captação de glicose e seu armazenamento na forma de glicogênio bem como sua utilização como substrato para lipogênese. Pode também aumentar o fluxo da via glicolítica e via das pentoses, inibindo glicogenólise, gliconeogênese e formação de corpos cetônicos. Tais efeitos se devem principalmente à ativação da glicoquinase (Gck) e da glicogênio sintase (Gys), bem como a inibição de enzimas de ação antagônicas a estas, como glicose-6-fosfatase (G6pc) e glicogênio fosforilase (CHEATHAM; KAHN, 1995).

A manutenção da homeostase da glicose em todo o corpo é dependente de uma resposta secretora apropriada de insulina pelo pâncreas e da sensibilidade apropriada dos tecidos aos efeitos da hiperinsulinemia e hiperglicemia, de modo a aumentar a absorção de glicose (BAJAJ; DEFRONZO, 2003). Por sua vez, os efeitos combinados de insulina e hiperglicemia para promover a utilização de glicose dependem fortemente de dois mecanismos acoplados: (1) a supressão da produção hepática de glicose (PHG) e (2) a estimulação da captação de glicose por tecidos periféricos, principalmente o muscular (DEFRONZO, 1997; MANDARINO et al., 2001). A captação de glicose pelo tecido é regulada pelo fluxo através de duas grandes vias metabólicas: a glicólise (que representa cerca de $90 \%$ da oxidação da glicose) e a síntese de glicogênio (BAJAJ; DEFRONZO, 2003).

\subsection{METABOLISMO HEPÁTICO}

Por sua vez, o fígado, órgão alvo deste estudo, além de ser considerado um tecido provedor de substratos energéticos, juntamente com a musculatura e o tecido adiposo; é um dos principais tecido-alvo dos hormônios reguladores do fluxo de energia no organismo, participando ativamente do metabolismo de lipídeos, proteínas e, principalmente, do metabolismo de carboidratos (ARIAS et al., 1988). 
Diversas vias bioquímicas intercelulares são continuamente ativadas e desativadas no fígado, muitas garantem a regulação de processos centrais do metabolismo energético, tais como glicólise, gliconeogênese e glicogenólise. Além de serem regulados pelo fígado esses eventos metabólicos ocorrem também neste órgão e estão diretamente ligados a distúrbios e patologias associadas como síndrome metabólica, diabetes, obesidade, etc.

A insulina e glucagon pancreáticos atingem o fígado via circulação porta e influenciam diretamente a homeostase energética sistêmica através de suas ações hepáticas. O glucagon previne a hipoglicemia por estimular uma produção de glicose à taxa suficiente para prover o sistema nervoso central (SNC) além de outras necessidades de glicose, como as geradas por exercício muscular, que diminuem reciprocamente os níveis de insulina, sendo que um declínio na taxa insulina/glucagon promove glicogenólise hepática (UNGER; DOBBS; ORCI, 1978).

Sob condições anabólicas, a insulina estimula a síntese de glicogênio ativando simultaneamente glicogênio sintase e inibindo de glicogênio-fosforilase (DENT et al., 1990). Este efeito da insulina é mediado através da fosfatidil inositol 3 quinase (PI3K), que inativa quinases tais como glicogênio sintase quinase 3 e ativa fosfatases, como fosfatase proteíca 1 (PPI). Vários estudos demonstraram de forma convincente que os inibidores da PI 3K e da glicogênio sintase podem inibir e abolir a síntese de glicogênio (SALTIEL; KAHN, 2001).

Do ponto de vista fisiológico, faz sentido que a ativação do transporte de glicose e da glicogênio sintase estejam ligadas a um mesmo mecanismo de sinalização, a fim de proporcionar uma estimulação coordenada e eficiente do metabolismo da glicose intracelular (BAJAJ; DEFRONZO, 2003).

Quando o glicogênio hepático é deplatado, baixo níveis de insulina liberam aminoácidos a partir da proteína muscular (MARIISS et al., 1971) e ácidos graxos livres a partir de triglicérides (MCGARRY; FOSTER, 1977) que provêm ao fígado substratos para gliconeogênese e ketogênese. Glucagon, por sua vez, promove tanto gliconeogênese quanto ketogênese no fígado. A combinação de baixa insulina com alto glucagon promove duas mudanças vitais: (1) provê o fígado de precursores energéticos e, (2) aumenta as capacidades gliconeogênica (EXTON; PARK, 1969) e de ketogênese (MCGARRY; WRIGHT; FOSTER, 1975) hepáticas. Com a produção de cetona subindo, esta está cada vez mais presente no SNC, como substrato 
energético alternativo à glicose, o que diminui a gliconeogênese e economiza proteínas, talvez um mecanismo adaptativo crucial para o prolongamento da sobrevivência no jejum (CAHILL, 1971).

Similarmente, durante exercício extenuante, com alta utilização de glicose pelos músculos (VRANIC; WRENSHALL, 1969), haverá um aumento marcante da produção de glicose hepática (VRANIC; KAWAMORI; WRENSHALL, 1974; VRANIC et al., 1976), em grande parte glucagon-mediada (GALBO; HOLST; CHRISTENSEN, 1975; GANDA et al., 1977), que previne a hipoglicemia e provê ajuste vital na sobrevivência durante situações de "luta- ou- fuga".

Além disso, após uma noite de jejum (estado pós-absortivo), a maior parte da utilização total de glicose ocorre em tecidos independentes da insulina, cerca de $50 \%$ no cérebro e $25 \%$ na área esplênica (fígado e tecidos gastrointestinais). A utilização basal de glicose, que na média é de aproximadamente $2,0 \mathrm{mg} / \mathrm{kg} / \mathrm{min}$, precisamente correspondente à liberação basal de glicose pelo fígado (BAJAJ; DEFRONZO, 2003).

Após a ingestão de uma refeição contendo glicose, a maior parte (cerca de $80 \%$ a $85 \%$ ) tem utilização no tecido muscular. A manutenção da homeostase da glicose é dependente de três processos intimamente relacionados: (1) de secreção de insulina pelas células $\beta$ pancreáticas, (2) a estimulação da captação de glicose pelos tecidos esplênicos (fígado e intestino) e periféricos (principalmente muscular), e (3) a supressão da produção de glicose hepática. Embora o tecido adiposo seja responsável por apenas uma pequena quantidade de utilização de glicose total do corpo (4\% a $5 \%$ ), ele desempenha um papel muito importante na manutenção da homeostase da total de glicose do corpo (BAJAJ; DEFRONZO, 2003).

A chamada resistência hepática a insulina $(\mathrm{RHI})$ pode ser bem exemplificada em estados patológicos como o diabetes tipo II, em que ocorre elevação na PHG mesmo com leve a moderada hiperinsulinemia de jejum, sendo o grau do acréscimo na PHG basal intimamente correlacionado ao grau de hiperglicemia em jejum (DEFRONZO et al., 1985; DEFRONZO; FERRANNINI; SIMONSON, 1989; DEFRONZO, 1997). Assim sendo, quando há RHI, o fígado, enquanto tecido-alvo da insulina, perde sua capacidade de responder apropriadamente ao estímulo hormonal, em condições euglicêmicas, o que também pode acontecer com a musculatura e tecido adiposo. 
Tendo em vista que a hiperinsulinemia é um potente inibidor de PHG (CHERRINGTON, 1999), a resistência hepática à ação da insulina deve estar presente no estado pós-absortivo para explicar a produção excessiva de glicose pelo fígado. A hiperglicemia per se também exerce uma ação supressiva poderosa sobre a PHG (DEFRONZO et al., 1983). Por isso, também deve haver resistência à glicose no que diz respeito ao efeito inibitório da hiperglicemia na PHG, e esta tem sido bem documentada (MEVORACH et al.,1998).

Sabe-se hoje que o controle do fígado sobre o metabolismo também está sob a influência de vários outros fatores, por exemplo, a microbiota intestinal, que recentemente vem sendo apontada por desempenhar um papel importante na manutenção da saúde do fígado e suas funções homeostáticas (LAU; CARVALHO; FREITAS, 2015).

A relação anatômica e funcional entre intestino e fígado, também através da circulação portal, possibilita que o fígado receba cerca de $70 \%$ do seu aporte sanguíneo a partir do intestino, o que favorece influências bidirecionais e, assim, representa a primeira linha de defesa contra os antígenos derivados do intestino (COMPARE et al., 2012).

Devido a este link com o intestino, o fígado é constantemente exposto a produtos bacterianos derivados do órgão. As células imunes, como as células de Kupffer (macrófagos) reconhecem padrões moleculares associados a agentes patogênicos moleculares (APMs) através de receptores de reconhecimento de padrões, por exemplo, os receptores de tipo Toll (TLR), desempenhando assim um papel importante na proteção sistêmica bacteriana (MENCIN; KLUWE; SCHWABE, 2009).

Estudos clínicos em mulheres com dietas controladas nas quais os níveis de colina foram variáveis, mostraram relação entre níveis de Gammaproteobacteria e Erysipelotrichiwere diretamente relacionados às alterações na gordura do fígado durante a depleção de colina. (SPENCER el al., 2011) Além disso, de maneira independente da obesidade, um estudo recente demonstrou que a flora intestinal marcadamente impacta o metabolismo dos lipídeos no fígado (LE ROY et al., 2013), podendo, inclusive, causar injúria hepática com fibrose do tecido, como visto em alguns experimentos envolvendo transplante de microbiota em camundongos (DE MINICIS et al., 2014). 


\subsection{GLICOCORTICÓIDES E O METABOLISMO ENERGÉTICO}

Os hormônios glicocorticóides corretamente secretados e circadianamente regulados são cruciais para o pleno controle sistêmico do metabolismo energético ao longo do dia e variações sazonais ambientais.

Os glicocorticóides estimulam a mobilização de proteínas para disponibilizar aminoácidos para a gliconeogênese, diminuindo síntese proteica e aumentando a proteólise (DARMAUN; MATTHEWS; BIER, 1988), além de ativar enzimas gliconeogênicas, exercendo assim um importante papel na manutenção da glicemia durante o jejum. Em situações extremas, em que ocorre ausência de glicocorticóides, a proteólise pode não ser suficientemente ativada podendo causar coma glicêmico e morte.

Em excesso os glicocorticóides também podem ser prejudiciais, acarretando em hiperglicemia, pois sua função é antagônica à da insulina. Nessas condições, inclusive, pode inibir sua secreção, assim como à captação de glicose pelo músculo e tecido adiposo. Tal efeito anti-insulínico parece ocorrer tanto ao nível do receptor de insulina como em etapas posteriores (GENUTH, 1993).

\subsection{REGULAÇÃO CIRCADIANA DO METABOLISMO ENERGÉTICO}

É principio fundamental que todos os seres vivos mantenham uma relação adequada entre a aquisição, armazenamento e o consumo energético, de modo a garantir sua sobrevivência. Para os animais é absolutamente necessário que o período de procura de alimento seja otimizado de forma a estar de acordo com o período circadiano de atividade da espécie e também perfeitamente sincronizado com o momento do dia em que a probabilidade de aquisição energética é a maior possível.

Nos mamíferos, o processo de aquisição energética tem condicionantes mais complexos e a sua expressão rítmica circadiana não está estritamente alocada ao dia ou à noite em todas as espécies, mas sim ao surto diário de atividade típico da espécie, isso de modo dependente da história filogenética da espécie e seu nicho ecológico. Dessa forma, de acordo com as adaptações particulares de cada espécie, 
as funções metabólicas se modificam circadianamente de acordo com o período de atividade/aquisição energética e o período de repouso/jejum.

Tendo em vista que a aquisição energética é condição absoluta para a manutenção da vida, é compreensível que fatores sinalizadores intrínsecos do estado metabólico do organismo (como glicemia, insulinemia, níveis dos estoques energéticos, sinalizadores da presença de nutrientes no trato gastrointestinal, etc.) devam também, paralelamente aos sincronizadores circadianos clássicos, regular e sincronizar a própria expressão rítmica circadiana da atividade e do repouso e, em particular, dos processos de aquisição, armazenamento, consumo e preservação de energia.

No contexto deste trabalho, a melatonina pode alterar o metabolismo energético de acordo com períodos ambientais específicos e assim alterar a utilização de glicose e outros substratos energéticos.

A importância da melatonina na regulação hepática da homeostasia energética já foi explorada por nós e por outros grupos. É sabido que o fígado é órgão-chave da manutenção da glicemia dentro de uma faixa estreita, função esta desempenhada por (a) sua capacidade metabólica direta de liberar glicose na circulação pela glicogenólise e a gliconeogênese e (b) pela sua função endócrina de secretar uma substância sensibilizadora à insulina (hepatic insulin sensitizing substance- HISS).

As flutuações circadianas das atividades metabólicas do fígado são bem conhecidas. O ritmo circadiano da produção hepática de glicose e da expressão de fosfoenolpiruvato carboxiquinase (PEPCK) no fígado de ratos apresenta-se variável de acordo com a oscilação diária da ativação nervosa autonômica e do comportamento alimentar (CAILOTTO et al., 2005; CAILOTTO et al., 2008). Também já foi demonstrado aumento da glicemia e redução dos níveis de melatonina noturna em indivíduos diabéticos (RADZIUK; PYE, 2006).

Nesse sentido, nosso grupo demonstrou que a ausência de melatonina provocada pela retirada cirúrgica da glândula pineal, ou pinealectomia, também diminui a produção hepática de proteína morfogênica óssea 9 (BMP9), um forte candidato a desempenhar o papel da HISS (CAPERUTO et al., 2008). Além disto, também observamos que a capacidade metabólica do fígado é modulada pela ausência de melatonina à medida que a pinealectomia desencadeia um estresse de 
retículo endoplasmático (RE) noturno no tecido hepático, como descrito detalhadamente a seguir.

Nestes animais, a pinealectomia desencadeou um quadro de resistência hepática noturna à insulina, caracterizada pela redução da fosforilação da proteína quinase $B(A K T)$ e aumento da expressão de PEPCK no período escuro. Estas alterações foram suprimidas pela reposição com melatonina.

A pinealectomia promoveu o aumento noturno de vários marcadores do estresse de RE, como activating transcription fator 4 e 6 (ATF4 e 6), proteína chaperone de ligação, (BiP) e CCAAT/enhancer-binding protein-homologous protein (CHOP), induzindo um ritmo circadiano de expressão destas proteínas, que estavam ausentes no fígado de animais intactos ou pinealectomizados tratados com melatonina. Proteínas que medeiam a resistência hepática à insulina induzidas pelo estresse do $\mathrm{RE}$, como tribble 3 protein (TRB3), regulatory-associated protein of mTOR (RAPTOR) e rapamycin-insensitive companion of mTOR (RICTOR), também estavam aumentadas no fígado de animais pinealectomizados apenas durante 0 período noturno; tal alteração também foi revertida pela reposição de melatonina.

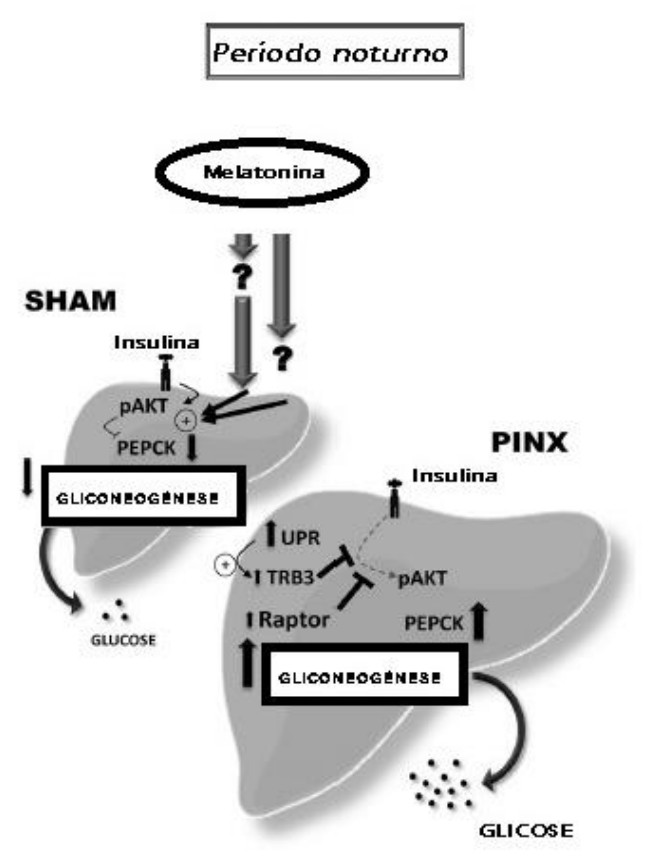

Figura 3: Diagrama representando o modelo proposto de resistência a insulina durante o período noturno no fígado de ratos pinealectomizados (PINX). Modificada de NOGUEIRA et al., 2011. 
Este foi o primeiro estudo que relatou alterações circadianas nas vias de sinalização ativadas pelo estresse de retículo endoplasmático relacionadas à ausência de melatonina e à resistência insulínica noturna (NOGUEIRA et al., 2011).

Um aspecto central das ações da melatonina sobre o metabolismo de carboidratos é que a pinealectomia promove aumento de duas vezes nos níveis de glicocorticóides circulantes. Esse efeito foi consistentemente observado em ratos pinealectomizados em três períodos do dia (às 8, 14 e 23 h), porém com manutenção do padrão de ritmicidade circadiana (ALONSO-VALE et al., 2004).

Estudos clássicos demonstraram que melatonina e pinealectomia têm ação modulatória sobre as glândulas adrenais (HEIMAN; PORTER, 1980; OXENKRUG; MCINTYRE; GERSHON, 1984). Entretanto, é amplamente conhecido que os glicocorticóides são potentes estimuladores da produção hepática de glicose. Até o momento não está esclarecido se os efeitos da melatonina sobre a regulação da produção hepática de glicose são diretos ou dependentes da ação dos glicocorticóides.

Tendo em vista que muitas das alterações metabólicas hepáticas observadas em animais pinealectomizados podem ser devidas ao reajuste da secreção e ação de glicocorticóides nestes animais, faz-se importante a elucidação da real participação desses hormônios nos eventos controladores do metabolismo energético hepático.

Nesta investigação visamos esclarecer se as principais alterações metabólicas energéticas observadas na pinealectomia e relatadas na literatura, geralmente no contexto de ausência e reposição de melatonina, não poderiam, na verdade, decorrer diretamente de um fator endócrino potencialmente mais atuante, pelos próprios efeitos clássicos sobre seus tecidos-alvo e através de seu principal mecanismo: sinalização intracelular via GR.

\subsection{HOMEOSTASIA GLICÊMICA, ESTRESSE OXIDATIVO E INFLAMAÇÃO HEPÁTICA}

Várias comorbidades conhecidas podem estar associadas à inflamação hepática, por exemplo: Sobrepeso visceral, hiperinsulinemia/ diabetes, hipertensão 
arterial e obesidade. Muitos destes são decorrentes principalmente do aumento crônico da glicemia.

É sabido que a doença hepática gordurosa não alcóolica (DHGNA), condição clínico-patológica presente na esteatose, esteatohepatite e uma série de formas mais graves de doenças hepáticas como a cirrose e carcinoma (LEVENE; GOLDIN, 2012) é parte da síndrome metabólica e presente em indivíduos que sofrem de diabetes mellitus tipo II, obesidade e dislipidemia (POWELL et al., 1990). $\mathrm{Na}$ patogênese da DGHNA, a resistência à insulina parece desempenhar papel fundamental (TARANTINO et al., 2007), sendo a progressão da doença normalmente associada ao estresse oxidativo e à sinalização inflamatória pelo tecido adiposo, culminando na forma inflamatória da patologia, a esteatohepatite (CORTEZ-PINTO; DE MOURA; DAY, 2006).

Embora atualmente não haja tratamento estabelecido para DHGNA, a maioria das estratégias terapêuticas tem como alvo a melhoria da resistência à insulina (RI), enquanto mecanismo fisiopatológico subjacente mais importante da DHGNA e da esteatose não alcoólica (ENA) (BUFIANESI; MCCULLOUGH; MARCHESINI, 2005).

A ligação entre resistência à insulina e DHGNA é bem conhecida e, a respeito, se destacam mudanças nos mecanismos que levam ao início e à progressão da doença pela sinalização da insulina alterada. O metabolismo lipídico alterado devido a resistência a insulina gera intermediários lipídicos que podem ativar diferentes quinases: Mammalian target of rapamycin (mTOR), c-Jun N-terminal kinase (JNK) e proteína quinase C original (nPKC) (SCHENK; SABERI; OLEFSKY, 2008). A ativação dessas quinases tem efeito de feedback negativo sobre a sinalização de insulina, contribuindo para a resistência a insulina e para o estado hiperinsulinêmico, que aumenta a liponeogênese de novo e piora o acúmulo de lipídios no fígado (ASRIH; JORNAYVAZ, 2013).

Sob o ponto de vista hormonal, já foi demonstrado que animais depletados de melatonina apresentam aumento de proteínas relacionadas à resistência hepática a insulina via estresse de RE, como TRB3 (NOGUEIRA et al., 2011). Segundo Du et al. (2003), o aumento de TRB3 no fígado de ratos resulta em hiperglicemia e inativação da AKT, conhecida por inibir a morte celular programada, a apoptose.

Independentemente do motivo que provoca a hiperglicemia crônica e a RI, se parte da adaptação metabólica gestacional como visto em ratas prenhes a termo 
(RODRIGUES et al., 2014), estas aceleram o processo de estresse oxidativo, que, por sua vez, acelera a glicação avançada, gerando um grupo heterogêneo de substâncias conhecidas como produtos finais da glicação avançada (AGEs).

Níveis elevados de intermediários reativos conhecidos como a-dicarbonilas ou oxoaldeídos formam a maior parte dos AGEs in vivo (DEGENHARDT, THORPE; BAYNES, 1998), que se acumulam no meio intracelular e ativam vias de sinalização envolvendo várias funções proteicas. Essas vias podem ser ativadas de modo dependente ou independente do receptor de produtos finais da glicação avançadaRAGE (GOH; COOPER, 2008).

A glicação avançada se dá ao longo de um período prolongado de tempo e afeta proteínas de baixa taxa de renovação, como componentes da membrana basal (colágeno IV), miosina, tubulina, fibrinogênio (VLASSARA, 1996) e componentes da matriz extracelular (DEGENHARDT; THORPE; BAYNES, 1998), que resultam, por fim, nas alterações estruturais provocadas por AGEs, como o que ocorre no diabetes. Tal processo se dá através do decorrente aumento de rigidez protéica, da resistência à digestão proteolítica, do aumento de proteínas de matriz extracelular e maior expressão de citocinas como o fator de crescimento transformador $\beta$ (TGF $\beta$ ) (FORBES et al., 2003; THROCKMORTON et al., 1995).

$\mathrm{Na}$ ocorrência da ligação de RAGE com AGEs há ativação de segundos mensageiros intracelulares, como a proteína quinase $C$ (PKC) e diacilglicerol que têm como alvo final o fator nuclear kappa B (NFkB), que é translocado ao núcleo onde ativa transcrição proteica específica, incluindo citocinas pró-inflamatórias (GOLDIN et al., 2006; SCHIEKOFER et al., 2003), sendo que a região promotora do receptor (RAGE) contem elementos de ligação ao NF-KB (LI; SCHMIDT, 1997).

Sabe-se que ligação AGE-RAGE nas células endoteliais, por exemplo, pode desencadear vários distúrbios nas funções celulares e ativar vias envolvendo: (a) NADPH oxidase, (b) geração de espécies reativas e oxigênio e (c) proteínas quinase de ação mitogênica (MKPs) (SCHMIDT; STERN, 2000).

Ainda, o aumento da concentração de glicose intracelular pode gerar inflamação pela via dos polióis, em que a aldose redutase reduz aldeídos a álcoois inativos na célula. Essa enzima possui baixa afinidade pela glicose e em níveis normoglicêmicos é pouco ativada, porém, em hiperglicemia duradoura, a aldose redutase também reduz o sorbitol, que posteriormente é oxidado à frutose, num 
processo que consome NADPH, essencial na redução da glutationa reduzida, importante antioxidante. $O$ resultado é maior suscetibilidade da célula ao estresse oxidativo num contexto pró-inflamatório (ENGERMAN; KERN; LARSON, 1994).

Além disso, desempenha papel crucial na inflamação hepática os mediadores inflamatórios que normalmente estão envolvidos em cascatas de sinalização relacionadas à inflamação, à fibrose e até à tumorgênese. Nesse contexto, os direcionadores do ritmo de progressão da inflamação são: Status imune do organismo, estresse de retículo endoplasmático, citocinas e outros sinalizadores em tecidos extra-hepáticos (TILG; MOSCHEN, 2010).

O fator alfa de necrose tumoral (TNF) também é capaz de dirigir a transdução de sinal para uma resposta apropriada aos diferentes estímulos devido à sua capacidade de se ligar aos seus receptores tipo 1 e 2 e assim controlar as ações induzidas na célula (SCHWABE; BRENNER, 2006). Após a ligação do TNF aos seus receptores, ambos os tipos recrutam moléculas TNF-R1, associated death domain protein (TRADD), TNF receptor-associated factor 2 (TRAF2) e receptorinteracting protein kinases (RIP) para ativar as vias de sinalização da IKK e JNK, relacionadas a mecanismos anti-apoptóticos e a proliferação. A indução da apoptose pode ocorrer via Caspase 8 (Figura 4).

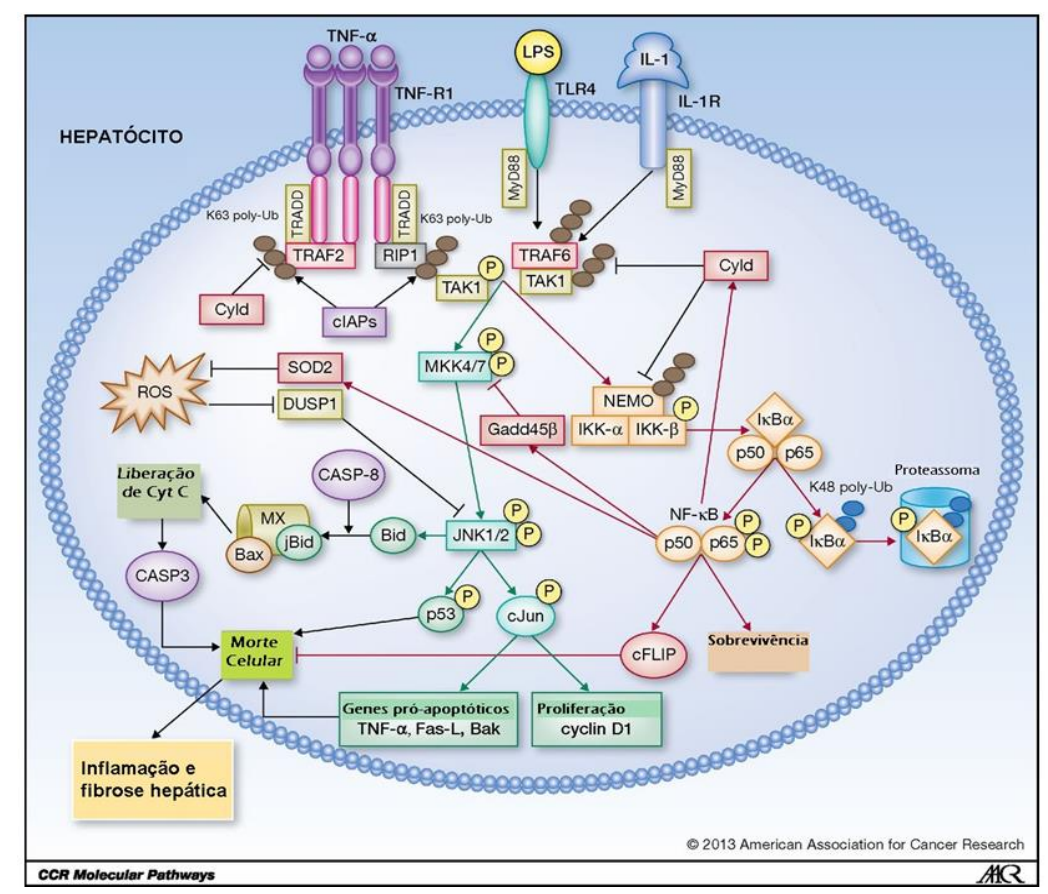

Figura 4: Regulação da morte celular e proliferação no fígado através das vias da NF-KB e JNK. Modificada de NIKOLAOU; SARRIS; TALIANIDIS, 2013. 
Complexos proteicos montados com os ligantes de TNF, receptores do tipo Toll e receptores de IL1 medeiam a ativação da mitogen-activated protein kinase kinase kinase 7 (TAK 1), cuja atividade é modulada por cylindromatosis (Cyld). TAK1 fosforila IKK $\beta$, que por sua vez fosforila a IkB, que conduz à sua degradação e libertação do NF-kB (p50- p65) mediada por fatores ubiquitina- proteassoma. NF-kB, por sua vez, é translocado ao núcleo para ativar a transcrição de genes prósobrevivência e induz a expressão de celullar caspase-8-like inhibitory protein (cFLIP) e superóxido dismutase 2 (SOD2), que inibem a apoptose e o acúmulo de espécies reativas de oxigênio (ROS).

TAK1 também fosforila mitogen-activated protein kinase kinase 4/ 7 (MKK4/7), que ativam JNK1/ 2. A ativação rápida e transitória de JNK em curto prazo induz a expressão de genes envolvidos no controle da proliferação. Já a ativação de JNK prolongada induz a expressão de genes pró-apoptóticos e estabiliza a P53 e a via apoptótica Bax/Bak-dependente. NF-kB regula a sua própria ativação via modulação da expressão de Cyld e a ativação de JNK via ativação de expressão de growth arrest and DNA damage-inducible protein beta (Gadd 45ß), que inibe MKK4/ 7. A ativação JNK também é modulada por acúmulo de ROS através da atividade da fosfatase 1 de dupla especificidade (DUSP 1) e caspase-3/ 8 (NIKOLAOU; SARRIS; TALIANIDIS, 2013).

\subsection{GLICOCORTICÓIDES E INFLAMAÇÃO}

Muitos atores do sistema endócrino têm efeitos sobre os níveis glicêmicos do organismo. Os glicocorticóides são hormônios hiperglicemiantes e que afetam muito o metabolismo lipídico, em condições fisiológicas. Assim como a melatonina, esses hormônios mostram influência sobre a melhora ou agravamento do quadro de inflamação hepática dependentemente da situação fisiológica sistêmica em que estão inseridos.

Os glicocorticóides são hormônios essenciais à vida, sendo a sobrevivência na ausência das glândulas adrenais e sem reposição hormonal limitada a poucos dias. Além de atuar na produção de glicose a partir de proteínas e facilitar o metabolismo das gorduras, os glicocorticóides afetam profundamente o sistema imune, exercendo 
grande influência sobre o complexo conjunto de reações ao traumatismo tecidual, infecção ou proteínas estranhas (GENUTH, 1993).

Os hormônios cortisol, corticosterona e todos os glicocorticóides sintéticos inibem fortemente a reação imune local imediata à lesão tecidual, através da inibição de ações coordenadas por prostaglandinas, leucotrienos, tromboxanos, óxido nítrico (NO) e fator ativador de plaquetas que normalmente atuam no aumento da permeabilidade microvascular para permitir maior infiltração de leucócitos e por isso tem grande aplicação terapêutica (CATO; WADE, 1996).

A inibição dessas reações pelo cortisol se deve pela supressão da síntese e liberação do ácido araquidônico, precursor de muitos mediadores imunes próinflamatórios e indução de lipocortina, que inibe a fosfolipase $A_{2}$ (libera o ácido araquidônico de sua ligação com a fosfatidilcolina) sendo a produção de ácido araquidônico pela fosfolipase $A_{2}$ limitante do processo de síntese de prostaglandinas, leucotrieno e tromboxanos (PERRS; FLOWER, 1990). Ademais, os glicocorticóides estabilizam os lisossomos e assim reduzem a liberação local de enzimas proteolíticas e de hialuronidase, que contribuem localmente para a formação de edema, também reduzem a expressão dos genes que codificam a cicloxigenase 2 (que atua na síntese de prostaglandinas na direção dos produtos inflamatórios) e a sintase do óxido nítrico (NOS) (ALLISON; LEE, 1989).

Sobre os tipos celulares, sabe-se que cortisol pode ainda inibir a diferenciação e proliferação de mastócitos inflamatórios locais. O cortisol inibe o recrutamento dos leucócitos humanos a partir dos vasos sanguíneos, diminuindo sua marginalização e adesão ao endotélio capilar via inibição da produção e fixação dos receptores específicos nas células endoteliais e dos peptídeos quimiotáxicos que atraem esse tipo celular (CALVANO et al., 1987). Além disso, o cortisol também inibe atividade fagocítica e bactericida dos neutrófilos da mesma maneira que inibe o chamado burst oxidativo que acompanha esses eventos, estimulado pelos leucotrienos.

Interessantemente, o número de neutrófilos liberados pela medula óssea na corrente sanguínea aumenta apesar de sua eficácia diminuir (UMEKI; SOEJIMA; 1990), e o número de eosinófilos também parece diminuir em resposta ao cortisol via estímulo apoptótico (SCHLEIMER, 1990).

Os glicocorticóides também podem agir suprimindo um processo base da resposta inflamatória crônica a uma lesão ao provocarem impedimento da formação 
de paredes conjuntivas em resposta à inflamação. Os glicocorticóides diminuem a contagem de linfócitos circulantes derivados do timo (células $\mathrm{T}$ ), devido à maior ocorrência de apoptose. Seu transporte para o local de estimulação antigênica e suas funções também são reduzidas resultando em comprometimento da imunidade mediada por células (ALLISON; LEE, 1989).

Quando um antígeno entra no organismo, é fagocitado por um macrófago que apresenta o antígeno para as células $\mathrm{T}$ e libera, simultaneamente, interleucina 1 (IL1) que ativa o subgrupo de células T auxiliares, que por sua vez, secretam várias interleucinas. Estas produzem cascatas de reações que geram número ainda maior de células $T$ ativadas e incrementam a produção de citocinas, influenciando diversas funções (GENUTH, 1993). Os glicocorticóides inibem a apresentação inicial do antígeno e a produção de IL1, IL2, IL6, interferon-y e outros produtos de macrófagos e linfócitos, afetando muito mais as células imunes em repouso do que as que já foram ativadas previamente. A proliferação de linfócitos é inibida nos estágios da interfase $G_{0}$ e $G_{1}$ e os monócitos têm sua diferenciação a macrófagos interrompida (LANSBERG; YOUNG, 1992). As células T ativadas recrutam e ativam os linfócitos $B$ que produzem anticorpos específicos contra os antígenos; os glicocorticóides também apresentam ação inibitória, mesmo que indireta, sobre a produção de anticorpos à medida que inibem a ativação das células $T$.

A atividade imune varia de acordo com o período ativo da espécie, nos humanos varia num padrão diurno oposto ao da secreção de cortisol, pois este inibe as respostas imunes; já as citocinas, por sua vez, estimulam a liberação de cortisol. Sendo assim, existe relação de feedback negativo entre o eixo hipotalâmicohipofisário-adrenal e o sistema imune.

A IL1, a IL6 e o TNF estimulam o hormônio corticotropina (CRH) e conseqüentemente a secreção de hormônio adrenocorticotrópico (ACTH), que estimula a zona fasciculada da adrenal a produzir glicocorticóides. Adicionalmente, os genes do $\mathrm{CRH}$ e ACTH são expressos por algumas células imunes, podendo haver efeitos autócrinos e parácrinos sobre a resposta imune (MASTORAKOS; CHROUROS; WEBER, 1993).

TNF é uma citocina que induz respostas de proliferação, produção de mediadores inflamatórios, morte celular e executa importante ação na patogênese do choque séptico. É produzida principalmente por macrófagos, mas também por 
vários outros tipos de células (WAJANT; PFIZENMAIER; SCHEURICH, 2003) em resposta ao lipopolissacarídeo de bactérias gram-negativas (LPS); além disso, é um importante ativador de vias de sinalização intracelulares pró-inflamatórias e próapoptóticas.

\subsection{MELATONINA E INFLAMAÇÃO}

Nos últimos vinte anos, vários pesquisadores demonstraram clara interferência da melatonina nas respostas imunes do organismo (LISSONI et al., 1994; MAESTRONI, 1998; NELSON; DEMAS, 1997; REITER; GUERRERO, 2002). Atualmente, a melatonina é conhecida por exercer importante papel na modulação das respostas inflamatórias e efeito protetor no choque séptico e hemorrágico.

A melatonina funciona como um antioxidante potente, eliminando o radical livre hidroxila e peroxinitritos- um oxidante reativo produzido a partir da reação de $\mathrm{NO} e$ de superóxidos (GILAD et al., 1997; REITER, 1995a; REITER, 1995b). Aumentos na produção de NO estão presentes em diversos processos patofisiológicos incluindo várias formas de choque circulatório e inflamação (NATHAN; XIE, 1994; SZABÓ, 1995). Sua produção se dá através das enzimas denominadas NOS, sintases de óxido nítrico, que convertem L-arginina em NO, este, por sua vez, desempenha funções na regulação cardiovascular (relaxamento endotelial), no sistema nervoso central e periférico (papel nos efeitos de aminoácidos excitatórios em curto prazo, bem como em longo prazo sobre o cérebro desenvolvimento, degeneração de neurônios e de células da retina, neurotransmissão, papel no efeito periférico analgésico da acetilcolina, entre outros) e em repostas imunes (ativação de macrófagos e células de Kupffer) e outros mecanismos de homeostasia (MONCADA; PALMER; HIGGS, 1991).

A isoforma induzível de NOS (iNOS) é responsável pela produção excessiva de NO na inflamação. Esta isoforma pode ser expressa em muitos tipos de células incluindo macrófagos, neutrófilos, células endoteliais, músculo liso vascular e condrócitos (NATHAN; XIE, 1994; SZABÓ, 1995), e sua expressão envolve múltiplas vias de transdução de sinal, incluindo a ativação de tirosina-quinases e translocação do NF-kB para o núcleo (MONCADA; PALMER; HIGGS, 1991; NATHAN; XIE, 1994). iNOS pode ser induzido pelo LPS, e por citocinas pró-inflamatórias, como o 
interferon- $\mathrm{\gamma}$ (IFN- $\mathrm{\gamma})$. Já os glicocorticóides, a trombina e uma variedade de citocinas antiinflamatórias podem suprimir a expressão de iNOS (NATHAN; XIE, 1994; SZABÓ, 1995).

Sabe-se que a vigília forçada por trabalho noturno leva à disruptura nos ritmos circadianos por afetar a síntese e secreção de melatonina pela glândula pineal, e assim influenciar diretamente a produção de citocinas inflamatórias e o sistema imune inato (CASTANON-CERVANTES et al., 2010). Em humanos, foi relatada alteração de secreção de melatonina e cortisol em trabalhadores noturnos que interfere diretamente nos níveis de IL1 $\beta$ salivar (REINHARDT et al., 2012). O padrão de secreção de IL1 $\beta$ parece ser mantido apenas na presença do ritmo circadiano adequado, portanto, tal padrão parece ser suscetível à mudança na secreção de melatonina pela pineal.

Efeitos imunomoduladores da melatonina foram demonstrados in vitro (GONZALEZ-HABA et al., 1995; MAESTRONI, 1995) e in vivo (PIERPAOLI, 1993). Os macrófagos e os linfócitos T auxiliares (TCD4) vêm sendo apontados como os principais alvos celulares das ações imunomoduladoras da melatonina (LISSONI et al., 1993; MAESTRONI; CONTI; LISSONI et al., 1994).

Funções da melatonina secretada por tecidos extra pineal sobre ativação de células polimorfonucleadas (neutrófilos, eosinófilos e basófilos) e mononuceladas (linfócitos e monócitos) também foram apontados no sangue (CARRILLO-VICO et al., 2004) e peritônio (MARTINS et al., 2004).

A melatonina é apontada como inibidora do NF-KB e do desencadeamento da resposta inflamatória (BENI et al., 2004; GILAD et al., 1998). A ativação do NF-KB em células monoculeadas durante a hiperglicemia do diabetes é um passo importante do desenvolvimento de complicações vasculares presentes no diabetes avançado (LISSONI et al., 1994; SZABÓ, 1995), o que parece ser decorrente de hiperglicemia crônica e/ou dos efeitos in vivo dos AGEs (CONTI; MAESTRONI, 1995; LISSONI et al., 1994; LISSONI et al., 1995).

Estudos diversos apresentam a idéia de que a hiperglicemia de curta duração também leva a disfunção celular endotelial (GILAD et al., 1997; MAESTRONI; CONTI; PIERPAOLI, 1987; REITER, 1995a; REITER, 1995b), ao aumento da produção de radicais livres (LISSONI et al., 1993; PIERPAOLI, 1993) e a ativação de NF-KB nas células vasculares dos músculos lisos (GILAD et al., 1997). Tais efeitos já 
foram observados em hiperglicemias de pequena duração, como a pós-prandial e outras induzidas experimentalmente (LISSONI et al., 1993; SZABÓ, 1995), indicando que a hiperglicemia induz vias de transdução de sinal in vivo que conduzem à ativação de NF-kB.

Desta maneira, hipotetizamos se seriam os glicocorticóides, modulados pela ausência de melatonina central, os principais agentes das alterações fisiológicas relacionadas ao metabolismo energético observadas na pinealectomia. Além disso, interessamo-nos se isso ocorreria através de mecanismos clássicos de ação e sinalização dos glicocorticóides. 


\section{OBJETIVO}

\subsection{OBJETIVO GERAL}

Avaliar a participação dos glicocorticóides nas alterações metabólicas energéticas e inflamatórias, principalmente hepáticas, após pinealectomia e bloqueio da sinalização do GR pelo agente farmacológico, RU 486.

\subsection{EXTRATÉGIA EXPERIMENTAL}

Primeiramente, visamos à avaliação dos efeitos da retirada da glândula pineal sobre variação diária de níveis glicêmicos e dos principais hormônios de interesse;

Posteriormente, avaliamos, no ZT 10, os efeitos da ausência de melatonina central e do bloqueio farmacológico da sinalização de glicocorticóides sobre:

- Parâmetros hormonais e glicêmicos;

- Parâmetros morfométricos: Adiposidade periabdominal, musculatura e densitometria óssea, peso corpóreo e de órgãos;

- Estimativa da tolerância à glicose e ao piruvato;

- Secreção de insulina estimulada por glicose pelas ilhotas pancreáticas.

No fígado, pontualmente no ZT 10:

- Conteúdo e fosforilação de protéinas alvo ou relacionadas à via dos glicocorticóides e resposta de fosforilação da AKT à insulina no fígado;

- Status transcricional de genes (via quantificação relativa de RNAm) para proteínas atuantes no controle metabólico hepático energético;

- Parâmetros histológicos e morfológicos celulares;

- Determinação do conteúdo de glicogênio hepático por ensaio de digestão.

- Conteúdo e fosforilação de protéinas alvo ou relacionadas à inflamação hepática.

- Status transcricional de genes (via quantificação relativa de RNAm) potencialmente atuantes na inflamação hepática. 


\section{MATERIAL E MÉTODOS}

\subsection{ANIMAIS}

Foram utilizados aproximadamente 200 ratos machos da linhagem Wistar, mantidos em caixas coletivas (com 4 animais por gaiola), sob condições de temperatura ambiental controlada (23 a $25^{\circ} \mathrm{C}$ ), ciclo claro/escuro de 12/12 horas (h), idade entre 60 e 100 dias e peso aproximado de 350 gramas (g), fornecidos pelo Biotério do Instituto de Ciências Biomédicas (ICB) da Universidade de São Paulo (USP, São Paulo-SP). Os ratos foram alimentados com ração padronizada para roedores Nuvilab CR1 (Nuvital Nutrientes S.A., Colombo, PR, Brasil) e água ad libitum. Com idade entre 35 e 50 dias de idade foram submetidos à cirurgia de remoção da glândula pineal, e, após 25 dias, foram utilizados nos experimentos de acordo com os princípios éticos de experimentação animais adotados pela Sociedade Brasileira de Ciências de Animais de Laboratório (SBCAL) sendo, o desenho experimental desta tese, aprovado pelo Comitê de Ética no Uso de Animais do ICB-USP, protocolo №. 103/ 2011.

\subsection{DELINEAMENTO EXPERIMENTAL}

\subsubsection{PERÍODOS DE INTERESSE EXPERIMENTAL}

Ao tratarmos de cronobiologia utilizamos a nomenclatura da área para especificar o exato momento de interesse experimental dentro de um ciclo circadiano; para tal, utilizamos os termos ZT (Zeitgeber time) ou ZTs (no plural), que por sua vez, deriva das palavras alemãs tempo (Zeit) e doador (Geber). O termo se refere a um estímulo que transmite informação temporal do ambiente a um relógio biológico.

ZT é uma nomenclatura utilizada para uniformizar os horários do ciclo circadiano sincronizado pelo claro-escuro ambiental, sendo que em ciclos $12 \mathrm{~h} / 12 \mathrm{~h}$ claro/escuro, convencionou-se que o ZT 10 representa $2 \mathrm{~h}$ antes da transição do claro para o escuro; independentemente do horário em que o biotério apaga ou acende as luzes, como pode ser visto no esquema abaixo: 
FOTOPERIOODO

ESCOTOPERÍODO

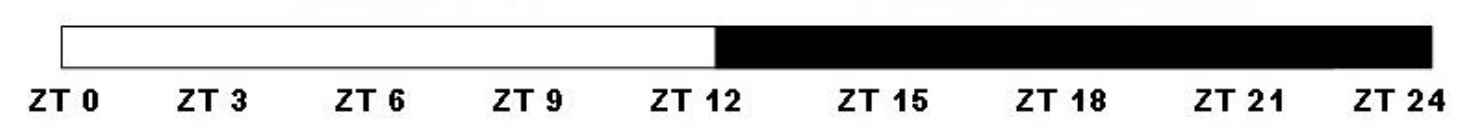

Figura 5: Um ciclo claro/escuro de 24 h, evidenciando a divisão do tempo em ZTs.

Após 25 dias de pinealectomizados e tratamento de um dos grupos por 5 dias com RU 486, os ratos foram decapitados para realização dos experimentos. Parte deles tiveram amostras coletadas em oito pontos igualmente distribuídos ao longo do dia: ZT 3, ZT 6, ZT 9, ZT 12, ZT 15, ZT 18, ZT 21 e ZT 24.

Tabela 1: Pontos ao longo do ciclo claro/ escuro de realização dos experimentos.

\begin{tabular}{|c|c|}
\hline Período de realização: & Experimento: \\
\hline $\begin{array}{c}\text { Ao longo de } 8 \text { ZTs ao longo de um dia, } \\
\text { igualmente distribuídos }\end{array}$ & $\begin{array}{l}\text { - Avaliação dos níveis glicêmicos e } \\
\text { hormonais (insulina, corticosterona } \\
\text { plasmáticas). }\end{array}$ \\
\hline $\begin{array}{l}\text { Durante período escuro, } \\
\qquad \text { Do ZT } 11 \text { ao ZT } 1\end{array}$ & - Dosagem de melatonina na urina. \\
\hline $\begin{array}{c}\text { ZT 10, ponto pré-transição da fase clara } \\
\text { para a fase escura. }\end{array}$ & $\begin{array}{l}\text { - Avaliação dos níveis glicêmicos e } \\
\text { hormonais (insulina e corticosterona } \\
\text { plasmáticas). } \\
\text { - Avaliação morfométrica e funcional in } \\
\text { vivo. } \\
\text { - Quantificação de mRNAs para genes } \\
\text { de interesse, relacionados à } \\
\text { sinalização por GR, metabolismo e } \\
\text { inflamação hepáticos. } \\
\text { - Avaliação de resposta de fosforilação } \\
\text { da AKT hepática após estímulo com } \\
\text { insulina. } \\
\text { - Análise histológica e do conteúdo de } \\
\text { glicogênio hepáticos }\end{array}$ \\
\hline
\end{tabular}


Recentemente, estabelecemos o ZT 10 como um ponto de interesse por ser tratar do início do período que antecede a transição do claro para o período escuro, o período ativo da espécie estudada, um roedor. Dessa forma, a maior parte dos experimentos ocorreu no ZT 10.

A escolha do ZT 10 para os estudos posteriores ocorreu porque: (a) é um período em que as concentrações de glicocorticóides são elevadas, sem variação significativa da glicemia, que poderia mascarar os efeitos diretos dos glicocorticóides; (b) estudos prévios do nosso grupo mostraram que as alterações do metabolismo hepático com concomitante aumento de corticosterona na prole de mães pinealectomizadas ocorrem no ZT 10 (FERREIRA et al., 2012).

\subsubsection{GRUPOS EXPERIMENTAIS E TRATAMENTO FARMACOLÓGICO}

Para a realização dos primeiros experimentos que constam nesta tese, os ratos foram separados em: (a) grupo controle (CTL) sem tratamento e submetido à cirurgia fictícia e, (b) submetido à pinealectomia (PINX). Os resultados apresentados com esses grupos experimentais constam em 8 ZTs num único dia e com "n" experimental de 8 animais/grupo/ZT.

Para a realização dos demais experimentos, os animais foram divididos em: (a) grupo controle, submetido à cirurgia fictícia (CTL); (b) grupo de animais submetidos à remoção cirúrgica da pineal, tratados com veículo (PINX); e (c) grupo de animais submetidos à pinealectomia e tratados com RU 486 (mifepristona) na dose de 100 $\mathrm{mg} / \mathrm{kg}$ de peso corpóreo, via subcutânea (KINOTE et al., 2012) (PINX RU) durante 5 dias (Figura 6).

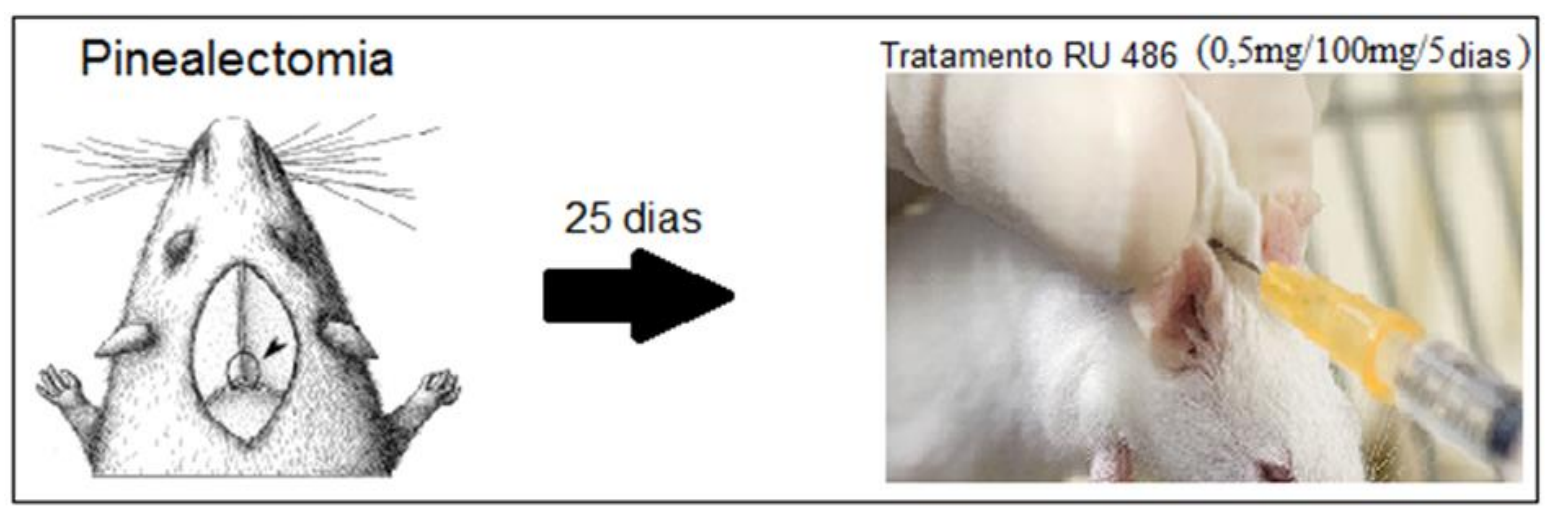

Figura 6: Pinealectomia e tratamento. 
Após 25 dias decorridos da cirurgia de pinealectomia, preparou-se a solução estoque de RU 486 para o tratamento dos animais (RU $486 \mathrm{em}$ etanol absoluto na concentração de $62,5 \mathrm{mg} / \mathrm{mL}$ ), que foi separada em 5 alíquotas de $2 \mathrm{~mL}$ às quais se adicionou $3 \mathrm{~mL}$ de água para injeção ou solução salina. Calculou-se o volume de tratamento individual a partir do peso corpóreo, sendo, por fim, etanol $20 \%$ utilizado como veículo. Os tratamentos com $\mathrm{RU} 486$ foram realizados no início do período diurno (entre os ZTs 2 e 3) de modo a impedir a sinalização e ação dos glicocorticóides via GR desde o inicio do ciclo circadiano.

\subsection{PROCEDIMENTO CIRÚRGICO}

Os ratos designados a sofrer a cirurgia para a remoção da glândula pineal foram anestesiados com seis semanas de vida com injeção intraperitoneal (ip.) de Hypno/® (Syntec, Cotia, SP, Brasil) na proporção de $4 \mathrm{mg} / 100 \mathrm{~g}$ de peso corpóreo, e, submetidos à cirurgia de remoção da glândula pineal de acordo com o método previamente descrito (MARTINS et al., 2001). Resumidamente, após anestesiados, os animais foram colocados em um aparelho estereotáxico para pequenos animais e então foi realizada uma abertura sagital no couro cabeludo, após divulcionamento da musculatura e fáscias que cobrem o crânio na região da junção sutural lâmbda, foi feita uma abertura circular usando-se uma broca construída especialmente para esse propósito. A peça óssea foi retirada expondo-se a confluência venosa posterior. Com uma pinça cirúrgica, a glândula pineal, localizada imediatamente abaixo da superfície foi retirada. Após breve hemostasia, o retalho ósseo foi recolocado e o escalpo suturado com um fio de algodão. Os animais foram tratados por 3 dias com analgésico (dipirona sódica, 14,3 mg/kg).

\subsection{DOSAGEM DE MELATONINA NA URINA}

Cerca de 20 dias após a pinealectomia, os ratos foram alocados em gaiolas metabólicas no ZT 11 para a coleta de urina. Durante o período de coleta fora disponibilizado somente água para o animal, para evitar contaminação da urina a ser analisada por alimento. Então, no ZT 1 do dia seguinte (após $14 \mathrm{~h}$ de permanência nas gaiolas metabólicas), os animais foram realocados de volta às suas caixas- 
padrão e os frascos com o conteúdo vesical noturno foram coletados. Foi então, mensurado na urina o metabolito da melatonina (6-sulfatoxi melatonina) por kit específico de imunoensaio enzimático para a sua determinação quantitativa (IBL, ref.54031, Hamburgo, Alemanha).

\subsection{GLICEMIA BASAL}

Antes da eutanásia ou experimentação, no ZT apropriado, os ratos foram submetidos a uma pequena incisão na cauda em que foram retirados aproximadamente $2 \mu \mathrm{l}$ de sangue para dosagem glicêmica em aparelho apropriado (Accu-Check, Roche, São Paulo, SP, Brasil), assim como em todos os experimentos que requereram dosagem glicêmica.

\subsection{RADIOIMUNOENSAIO PARA AFERÊNCIA DE INSULINEMIA}

A determinação da quantidade de insulina plasmática foi determinada por radioimunoensaio. Para tanto, a solução reagente inclui uma quantidade conhecida de anticorpo, uma quantidade conhecida do hormônio marcado radioativamente (insulina marcada com iodo ( ${ }^{125}$ I, Amersham Pharmacia Biotech, Amersham, Reino Unido) e uma quantidade desconhecida de hormônio não radioativo (amostra). Como as duas formas de hormônio, radioativo e não-radioativo, competem por um mesmo número de locais de ligação ao anticorpo, quanto mais hormônio não radioativo estiver presente, menos o hormônio radioativo irá se ligar. O complexo insulina- anticorpo marcado formado foi precipitado com polietilenoglicol (PM 6000) e dosado em contador tipo gama (PerkinElmer, Turku, Finlândia). Uma curva padrão foi preparada, na qual a relação ligado/livre para o hormônio radioativo é plotada com função da concentração do hormônio não radioativo: A relação ligado/livre do hormônio radioativo é maior quanto menor número de hormônio não radioativo estiver presente. A curva padrão foi utilizada para determinar a concentração do hormônio em cada amostra. 


\subsection{DOSAGEM DE CORTICOSTERONA PLASMATICA}

Após coleta de sangue portal (veia porta-hepática) em tubo com anticoagulante (EDTA), o plasma dos animais foi então obtido por centrifugação (1200 g/15 minutos [min]) e as concentrações plasmáticas de corticosterona foram obtidas por meio de ensaio imune enzimático (ELISA) conforme especificações do fabricante (Corticosterone: Neogen, Lexington, KY, EUA).

\subsection{MORFOMETRIA POR IMAGEAMENTO IN VIVO E PESAGEM}

Decorridos aproximadamente 25 dias da pinealectomia e finalizado 0 tratamento farmacológico, os animais foram anestesiados com injeção de tiopental de sódio (50 mg/kg de peso corpóreo) e submetidos ao sistema de imageamento in vivo MS FX PRO Cadestream (Bruker, Woodbridge, CT, EUA) que oferece uma imagem de raio $X$ com sistema de rotação de 360 de imageamento. As fotos foram adquiridas utilizando-se dois ou mais filtros, cujas imagens foram mescladas e submetidas à análise após ampliação geométrica padrão de $3.3 \mathrm{X}$ em muito alta resolução.

Além da análise supracitada, foram aferidos: peso corpóreo total dos animais e pesos do fígado e tecido adiposo epididimal por pesagem simples, no caso dos tecidos, após dissecação.

\subsection{TESTE DE TOLERÂNCIA INTRAPERITONEAL À GLICOSE (ip.GTT)}

A fim de se estimar a tolerância à glicose dos indivíduos analisados, estes foram submetidos ao teste de tolerância intraperitoneal à glicose. No dia do experimento, os animais foram mantidos em jejum de $12 \mathrm{~h}$ e, no ZT 10, tiveram suas glicemias basais medidas a partir de sangue total colhido de uma pequena incisão na cauda do animal.

Após essa etapa, os animais receberam uma injeção intraperitoneal de glicose ( $2 \mathrm{~g} / \mathrm{kg}$ de peso corpóreo de solução $20 \%$ de D-glicose) e tiveram suas glicemias individualmente medidas nos tempos 5, 10, 15, 30, 60 e 120 min. A área sobre a 
curva da glicemia versus (vs.) tempo foi calculada acima de cada linha base (glicemia basal) individual para estimar a tolerância à glicose.

\subsection{TESTE DE TOLERÂNCIA INTRAPERITONEAL AO PIRUVATO (ip PTT)}

O teste de tolerância intraperitoneal ao piruvato foi realizado com a finalidade de estimar a taxa de gliconeogênese (YAO; NYOMBA, 2008). Os ratos foram mantidos em jejum de $12 \mathrm{~h}$ antes do experimento e receberam uma injeção intraperitoneal de solução de piruvato de sódio $(250 \mathrm{mg} / \mathrm{mL})$ também no ZT 10. A dosagem final de piruvato foi $2 \mathrm{~g} / \mathrm{kg}$ de peso corpóreo. A glicemia então foi medida nos tempos 0, 15, 30, 60, 90, 120 e $150 \mathrm{~min}$, a partir de sangue total colhido de uma pequena incisão na cauda do animal. A área sobre a curva da glicemia vs. tempo foi calculada acima de cada linha base (glicemia basal) individual para estimar a glicose total sintetizada do piruvato.

\subsection{ANÁLISES DE SECREÇÃO ESTÁTICA DE INSULINA ESTIMULADA POR GLICOSE (GSIS) EM ILHOTAS PANCREÁTICAS}

\subsubsection{EXTRAÇÃO DE ILHOTAS PANCREÁTICAS}

Após narcose induzida por mistura de gás contendo $30 \%$ de $\mathrm{O}_{2}$ mais $70 \%$ de $\mathrm{CO}_{2}$ os animais foram submetidos à laparotomia e exposição do ducto biliar, o mesmo foi clampeado na sua extremidade distal, junto ao duodeno, e dissecado próximo ao pedículo hepático, por onde foi introduzida uma cânula de polietileno e injetada retrogradamente cerca de $20 \mathrm{~mL}$ de solução de Hanks contendo colagenase tipo IV (50 mL de Hanks/34 mg de colagenase). O pâncreas foi retirado e colocado em uma placa de Petri para dissecação de gânglios linfáticos, gorduras e vasos sanguíneos. O tecido foi colocado em tubo cônico em banho-maria a $37^{\circ} \mathrm{C}$ durante 25 min, seguido de agitação manual no mesmo banho-maria por mais 1 min, para a digestão da parte exócrina do pâncreas. Posteriormente foram feitas sucessivas lavagens do conteúdo do tubo, para ressuspensão do material isolado com solução de Hanks (LACY; KOSTIANOVSKY, 1967). A solução final foi depositada em placa 
de Petri para coleta das ilhotas com o emprego de micropipeta e lupa. De 150 a 300 ilhotas isoladas foram coletadas e lavadas com solução Hanks.

\subsubsection{AVALIAÇÃO DA SECREÇÃO ESTÁTICA DE INSULINA}

Para avaliação da secreção estática de insulina, foram utilizados grupos de cinco ilhotas em triplicata para cada condição experimental. As amostras foram préincubadas em $500 \mu \mathrm{l}$ de Krebs-Henseleit em 5.6 milimolar (mM) de glicose suplementado com albumina bovina (0,2\%), e incubadas em 5.6, 8.3, 11.1 e 16.7 $\mathrm{mM}$, permanecendo em banho a $37{ }^{\circ} \mathrm{C}$ por $60 \mathrm{~min}$. Após o período de incubação, $450 \mu \mathrm{l}$ do sobrenadante foram removidos e estocados a $-20^{\circ} \mathrm{C}$ para dosagem de insulina por radioimunoensaio. A determinação da quantidade de insulina secretada pelas ilhotas in vitro, em cada uma das concentrações, foi determinada por radioimunoensaio, técnica supracitada, também utilizada para a dosagem da insulinemia plasmática.

\subsection{ANÁLISES DE LIPÍDEOS CIRCULANTES}

Os parâmetros circulantes de colesterol total, colesterol LDL e triglicérides no soro foram determinados utilizando-se kits comerciais. Após a decaptação dos ratos foi coletado o sangue e este rapidamente centrifugado a 3.000 rotações por minuto (rpm) por 15 min. O soro obtido foi utilizado conforme orientação do fabricante para determinação do Colesterol Total (LabTest, ref. 76-2/100, Lagoa Santa, MG, Brasil) lido à $490 \mathrm{~nm}$ em espectrofotômetro, bem como Colesterol LDL (LabTest, ref. 111) lido à 500 nm e Triglicérides (LabTest, ref. 87-2/100) lido à 405 nm.

\subsection{EXTRAÇÕES PROTÉICAS E IMUNOBLOTTING DO FÍGADO}

Os fragmentos de tecido hepático coletados após eutanásia dos animais foram homogeneizados com homogeinizador Polytron® (PT 2100, Kinematica AG, Lucerne, Suíça) em tampão de extração (1\% de SDS, 100 mM de Tris [pH 7,4], 100 $\mathrm{mM}$ de pirofosfato de sódio, $100 \mathrm{mM}$ de fluoreto de sódio, $10 \mathrm{mM}$ de EDTA, $100 \mathrm{mM}$ de ortovanadato de sódio e $250 \mathrm{mM}$ de $\mathrm{NaCl}$ ). Após a homogeneização, as 
amostras foram incubadas por $10 \mathrm{~min}$ a $96{ }^{\circ} \mathrm{C}$ e em seguida centrifugadas para a remoção do material insolúvel $\left(12.000 \mathrm{~g} / 10 \mathrm{~min} / 4{ }^{\circ} \mathrm{C}\right)$. Parte do sobrenadante foi utilizada para determinação do conteúdo protéico por espectrofotometria com reagente Bradford (Bio-rad, Hercules, CA, EUA) segundo o método descrito por Bradford (BRADFORD, 1976) e o restante foi diluído em tampão Laemmli (LAEMMLI, 1970) em volume de 1:5 (v/v) contendo ditiotreitol $100 \mathrm{mM}$ e incubado por 10 min a $96{ }^{\circ} \mathrm{C}$ e submetido à separação eletroforética em gel de poliacrilamida 6 a 10\% (\% T) com dodecil sulfato de sódio (SDS-PAGE) em aparelho para minigel (Mini Protean III, Bio-rad, Hercules, CA, EUA).

\subsection{IMUNOBLOTTING APÓS ESTÍMULO COM INSULINA}

Para a realização da técnica de imunoblotting com estímulo de insulina os animais foram previamente anestesiados com solução de tiopental sódico (5 mg/ $100 \mathrm{~g}$ de peso corpóreo, ip.) após $12 \mathrm{~h}$ de jejum e tiveram um fragmento do fígado coletado. Posteriormente, a veia cava foi exposta e injetou-se $0,1 \mathrm{~mL}$ de uma solução de insulina $\left(10^{-4} \mathrm{M}\right)$. Passados de 30 a 90 segundos (s), coletou-se outro fragmento do fígado do animal para avaliar a fosforilação da AKT estimulada por insulina.

Após feitas as eletroforeses com os homogenatos protéicos hepáticos obtidos das técnicas de extração protéica sem e com o estímulo com insulina, as proteínas presentes nos géis foram transferidas para membranas de nitrocelulose (Bio-rad, Hercules, CA, EUA) em aparato para transferência elétrica semi-seca (Bio-rad, Hercules, CA, EUA). As membranas foram posteriormente bloqueadas com uma solução de albumina sérica bovina ou leite desnatado em pó a $5 \%$ por $2 \mathrm{~h}$ a temperatura ambiente. Após o bloqueio, as membranas foram incubadas com anticorpos primários (Santa Cruz Biotechnology Inc., Heidelberg, Alemanha) contra as proteínas de interesse (p-AKT, GR1, 11ß HSD1, DexRas, H6pd, GLUT2, iNOS, Caspase 3C, TLR4, p-STAT3, STAT3 e $\beta$ actina) por $4 \mathrm{~h}$ à temperatura ambiente ou $12 \mathrm{~h}$ a $4{ }^{\circ} \mathrm{C}$. A seguir, as membranas foram incubadas com anticorpo secundário conjugado à peroxidase (Amersham Pharmacia Biotech, Amersham, RU) e reagentes de detecção do kit de quimioluminescência (ECL, Amersham 
Pharmacia Biotech, Amersham, RU). As membranas foram então expostas durante tempos variados ao sistema de fotodocumentação DNR MF-Chemi BIS 3.2 (Bioamerica, Miami, FL, EUA). Depois de reveladas, as imagens foram submetidas à análise de densitometria óptica utilizando o software Image $J(N I H$, Bethesda, MD, EUA).

\subsection{TRANSCRIÇÃO REVERSA E PCR TEMPO REAL}

\subsubsection{EXTRAÇÃO DE RNA TOTAL DO FÍGADO}

Fragmentos de $0,1 \mathrm{~g}$ de tecido hepático foram processados imediatamente ou congelados em nitrogênio líquido e o RNA total das amostras foi extraído pela técnica com Trizol $\circledast$ (Invitrogen $^{\mathrm{TM}}$, Calsbad, CA, USA). Para isso, acrescentou-se à amostra $1 \mathrm{~mL}$ de solução de Trizol $\Theta$ e foi feita a homogeneização em Polytron ${ }^{\circledR}$. Após esse procedimento foram adicionados $0,2 \mathrm{~mL}$ de clorofórmio ao homogeneizado e posteriormente realizada centrifugação a $12.000 \mathrm{~g}$ para recuperação da fase aquosa superior. A esta foi adicionada $500 \mu \mathrm{l}$ de isopropanol e feita uma nova centrifugação a $12.000 \mathrm{~g}$ para obtenção do precipitado, ao qual foi adicionado etanol $75 \%$ de modo a realizar a ressuspensão do material que novamente foi centrifugado a $12.000 \mathrm{~g}$. O precipitado final, sem resíduo de etanol, foi ressuspenso em 100 a $200 \mu \mathrm{l}$ de água DEPC (água contendo 1\% de dietil pirocarbonato- Sigma, S. Louis, MO, EUA).

A concentração de RNA total e sua pureza foram calculadas em aparelho espectrofotômetro nanodrop ${ }^{\circledR}$ (Thermo Fisher Scientific, Wilmington, DE, EUA), utilizando a água DEPC como branco. A leitura na absorbância $A_{260}$ provê a concentração calculada de RNA por volume escolhido (normalmente $\mu \mathrm{g} / \mu \mathrm{l}$ ). A relação de leituras $A_{260} / A_{280}$ obtidas permitiram estimar a pureza do ácido nucléico na amostra, considera-se uma relação 260/280 OD como satisfatória entre os valores de 1,8 e 2 . Ainda para verificação da qualidade das amostras, foi realizada eletroforese em gel de agarose $1 \%$ e consideradas íntegras as amostras que apresentaram bandas ribossomais $18 \mathrm{~S}$ e $28 \mathrm{~S}$ intactas à visualização por transiluminação com luz ultravioleta. 


\subsubsection{TRANSCRIÇÃO REVERSA}

As amostras com $2 \mu \mathrm{g}$ de RNA total foram submetidas à reação de transcriptase reversa com primers randômicos. Para isso, foi adicionado em cada amostra: Tampão da enzima (50 mM de Tris- $\mathrm{HCl} \mathrm{pH}$ 8,3; $75 \mathrm{mM}$ de $\mathrm{KCl} ; 3 \mathrm{mM}$ e $\mathrm{MgCl}_{2}$ ), DTT (10 mM), mistura de dNTPs (0,5 mM cada), primers randômicos (150 ng), inibidor de RNAse (40 U) e a enzima SuperScript II (200 U; Invitrogen, EUA), em volume final de $20 \mu \mathrm{l}$. As reações foram incubadas por 50 min a $42{ }^{\circ} \mathrm{C}$, seguida de aquecimento a $70{ }^{\circ} \mathrm{C}$ por 15 min para desnaturação da enzima. Ao final da reação pôde-se então construir cDNAs (DNAs completares) a partir do RNA mensageiro (RNAm) que foram amplificados por PCR (reação da polimerase em cadeia).

\subsubsection{PCR EM TEMPO REAL}

Seguindo-se criteriosamente as recomendações do fabricante Fast SYBR® Green Master Mix (Applied Biosystems, Life Technologies, Foster City, CA, EUA) foram realizados os experimentos de PCR em tempo real em equipamento Stratagene Mx3005P (Agilent technologies, La Jolla, CA, EUA). A análise dos resultados foi feita utilizando o software (MX PRO) disponibilizado pelo fabricante. Resumidamente, para cada condição acima descrita, foram calculados os valores de $\Delta$ Ct para cada gene de interesse $(\Delta \mathrm{Ct}=\mathrm{Ct}$ gene de interesse $-\mathrm{Ct}$ gene constitutivo $)$. Em seguida, tomando-se como referência os valores de $\Delta \mathrm{Ct}{ }^{\mathrm{CTL}}$, calculou-se os valores de $\Delta \Delta \mathrm{Ct}$, resultados da subtração $\Delta \mathrm{Ct}$ CTL $-\Delta \mathrm{Ct}$ PINX ou PINX RU. Os primers utilizados foram: GR, 11ßHSD1, DexRas1, H6pd, GLUT2, PCK-1, G6pc, Gys2, ACC a, Me1, Me2, Me3, Fas N, Dgat2, Mttp, Sec22b, CD36, LXR, NF-KB, TNF $\alpha$, IL 1a, IKK $\beta$, IL1 R1, IL1 RN, NOS2, Caspase3, SOD2, P53, TGF $\beta 1$, STAT3 e Rpl37a foi usado como gene constitutivo normalizador. Os primers utilizados estão listados na tabela abaixo (Tabela 1). 
Tabela 2: Sequências sense e antisense dos primers utilizados no PCR tempo-real.

\begin{tabular}{|c|c|c|}
\hline Gene & Sense / Antisense & Produto(bp) \\
\hline GR & $\begin{array}{l}\text { TCTCCTCCATCCAGCTCGTCAGC } \\
\text { TGCAGCTTCCACATGTCAGCACC }\end{array}$ & 112 \\
\hline $11 \beta$ HSD1 & $\begin{array}{l}\text { GTGCGAAGAAGCATGGAGGTC } \\
\text { CCGAGGACACAGAGAGTGATGG }\end{array}$ & 241 \\
\hline DexRas1 & $\begin{array}{l}\text { CATCTGGCAATCATCCGTTTCC } \\
\text { TCAATCTCCCGCTGCTCCAC }\end{array}$ & 246 \\
\hline H6pd & $\begin{array}{l}\text { GCTTTGACCTGGTGCTGCTAGG } \\
\text { AGGCTGAGGCTCATGCGTTG }\end{array}$ & 145 \\
\hline GLUT2 & $\begin{array}{l}\text { CATTGCTGGAAGAAGCGTATCAG } \\
\text { GAGACCTTCTGCTCAGTCGACG }\end{array}$ & 87 \\
\hline PCK-1 & $\begin{array}{l}\text { TGGTCTGGACTTCTCTGCCAAG } \\
\text { AATGATGACCGTCTTGCTTTCG }\end{array}$ & 285 \\
\hline G6pc & $\begin{array}{l}\text { ACCTTCTTCCTGTTTGGTTTCGC } \\
\text { CGGTACATGCTGGAGTTGAGGG }\end{array}$ & 206 \\
\hline Gys2 & $\begin{array}{l}\text { CCAAAGAATCATCCAGAGGAACC } \\
\text { TACTTAAAGCCATCCGTCGTTG }\end{array}$ & 168 \\
\hline $\operatorname{ACC} \alpha$ & $\begin{array}{l}\text { TGCTTATATTGTGGATGGCTTG } \\
\text { TTCTACTGTCCCTTCTGGTTCC }\end{array}$ & 184 \\
\hline Me1 & $\begin{array}{l}\text { ACTGATGGAGAGCGAATCCTCG } \\
\text { TTTCTGTGCCCACGTCCAAAG }\end{array}$ & 145 \\
\hline Me2 & $\begin{array}{l}\text { GCAGGTGCTTGTTTGCCAGTG } \\
\text { TTGGGATGTCAGTGCCTTTGC }\end{array}$ & 188 \\
\hline Me3 & $\begin{array}{l}\text { CCCACAGCAATTATAGGTGTCGC } \\
\text { TCCACTGGCAAAGATTCCTCG }\end{array}$ & 183 \\
\hline FAS N & $\begin{array}{l}\text { TGGTGAAGCCCAGAGGGATC } \\
\text { CACTTCCACACCCATGAGCG }\end{array}$ & 127 \\
\hline Dgat2 & $\begin{array}{l}\text { AAGCCCATCACCACCGTTG } \\
\text { TTCCTTCCAGGAGCTGGCAC }\end{array}$ & 206 \\
\hline Mttp & $\begin{array}{l}\text { TATGACCGTTTCTCCAAGAGTGG } \\
\text { TCAAGGTTCTCCTCTCCCTCATC }\end{array}$ & 248 \\
\hline Sec22b & $\begin{array}{l}\text { CGTGCTCGGAGAAATCTCGG } \\
\text { AACACGGCTACTGCTGCAAGC }\end{array}$ & 218 \\
\hline CD36 & $\begin{array}{l}\text { TCTTCCAGCCAACGCCTTTGC } \\
\text { TGCACTTGCCAATGTCCAGCAC }\end{array}$ & 119 \\
\hline LXR & $\begin{array}{l}\text { CAATGATGCTGAATTTGCTCTGC } \\
\text { CACTTGCTCTGAATGGACGCTG }\end{array}$ & 223 \\
\hline
\end{tabular}




\begin{tabular}{|c|c|c|}
\hline NF-kB & $\begin{array}{l}\text { CTCAAGAACAGCAAGGCAGCAC } \\
\text { AGAGGTGTCGTCCCATCGTAGG }\end{array}$ & 266 \\
\hline TNF $\alpha$ & $\begin{array}{l}\text { GTGATCGGTCCCAACAAGGAGG } \\
\text { GAAGTGGCAAATCGGCTGACG }\end{array}$ & 329 \\
\hline IL1 a & $\begin{array}{l}\text { TGCCTACTCATCGGGAGGAGAC } \\
\text { AATCTATCATGGAGGGCAGTCCC }\end{array}$ & 284 \\
\hline Ikk $\beta$ & $\begin{array}{l}\text { TGAGCGTCTGGAGAAGTGGC } \\
\text { CTGAGTAGCAGGCTTGTCAGGG }\end{array}$ & 298 \\
\hline IL1 R1 & $\begin{array}{l}\text { GAACGGCAGGAATGTGACCC } \\
\text { GGCACAATGAGACAAATGAACCC }\end{array}$ & 295 \\
\hline IL1 RN & $\begin{array}{l}\text { TACCTTCATCCGCTCCGAGAC } \\
\text { GCAGTGCTATTGGTCTTCCTGG }\end{array}$ & 172 \\
\hline NOS2 & $\begin{array}{l}\text { CGAGTTGTGGATTGTTCTTCGC } \\
\text { CGTCTCTTCCGTGGCAAAGC }\end{array}$ & 195 \\
\hline $\begin{array}{c}\text { Caspase } \\
3\end{array}$ & $\begin{array}{l}\text { AACGAACGGACCTGTGGACC } \\
\text { GTGACTGGATGAACCATGACCC }\end{array}$ & 269 \\
\hline SOD2 & $\begin{array}{l}\text { GCTGGAGCCGCACATTAACG } \\
\text { CCCAAAGTCACGCTTGATAGCC }\end{array}$ & 268 \\
\hline P53 & $\begin{array}{l}\text { CGTTGCTCTGATGGTGACGG } \\
\text { AGCGTGATGATGGTAAGGATGG }\end{array}$ & 230 \\
\hline TGF $\beta 1$ & $\begin{array}{l}\text { GAGAAGAACTGCTGTGTACGGC } \\
\text { GTGTGTCCAGGCTCCAAATG }\end{array}$ & 136 \\
\hline STAT3 & $\begin{array}{l}\text { AGAGACCCACTCCTTGCCAGTC } \\
\text { TAGCCCATGTGATCTGACACCC }\end{array}$ & 280 \\
\hline Rpl37a & $\begin{array}{c}\text { CAAGAAGGTCGGGATCGTCG } \\
\text { ACCAGGCAAGTCTCAGGAGGTG }\end{array}$ & 290 \\
\hline
\end{tabular}

\subsection{ANÁLISES HISTOLÓGICAS HEPÁTICAS}

\subsubsection{HISTOLOGIA}

A análise histológica consistiu na secção de uma porção do fígado retirada do animal anestesiado, sendo em seguida fixada em solução Bouin, seguindo-se, posteriormente, a desidratação e o procedimento para inclusão em parafina, conforme técnica histológica de rotina (CHEAD et al., 2013).

Cortes seriados de 5 a $6 \mu \mathrm{m}$ foram confeccionados em micrótomo rotativo Leica ${ }^{\circledR}$ RM 2155 (Leica Biosystems, Nußloch, Alemanha) utilizando-se navalhas de 
vidro. Para a descrição morfológica, as lâminas foram coradas com hematoxilina e eosina- H.E. (BEHMER et al., 1975). Para a detecção de polissacarídeos neutros foi utilizada a técnica do Ácido periódico de Schiff- P.A.S. (JUNQUEIRA et al., 1983).

Para tal, lâminas contendo os cortes foram transferidas para a solução de ácido periódico 4\% durante $15 \mathrm{~min}$, sendo posteriormente lavadas em água destilada. Em seguida o material foi colocado no reagente de Schiff, em ambiente escuro, por 10 min e as lâminas seqüencialmente foram lavadas em água destilada (três banhos de 1 min) e, após a secagem, foram montadas com resina e recobertas por lamínula.

Todas as laminas foram analisadas no fotomicroscópio Nikon Eclipse TiU ${ }^{\circledR}$ (Melville, NY, EUA) e as imagens foram digitalizadas por meio do programa NIS Elements BR 3.1 software (Nikon, São Paulo, SP, Brasil).

\subsubsection{MORFOMETRIA CELULAR}

As medidas celulares das imagens dos cortes histológicas foram analisadas por meio do programa NIS Elements BR 3.1 com devida calibração para a objetiva utilizada (10x e 40x). Para avaliação quantitativa dos cortes feitos em H.E. e P.A.S., estabelecemos a quantidade de 225 campos/grupo para as analises do fígado. A escolha dos campos foi determinada de forma aleatória. Todas as imagens de todos os grupos foram também visualizadas no microscópio óptico Leica ${ }^{\circledR}$ (DM 4000B) com câmera Leica ${ }^{\circledR}$ (DFC 280) ligada ao computador AMD Athlon ${ }^{\mathrm{TM}}$ equipado com placa de vídeo NVIDIA (GeForce4 MX4000) e capturadas antes do processo de quantificação para a padronização da intensidade da luz do microscópio e altura do condensador.

Em lâminas de fígado coradas com H.E., foram tomadas as medidas celulares e feitas as determinações de densidade e volume da célula, para tal, utilizou-se um sistema teste formado por pontos eqüidistantes entre si e por linhas de inclusão e exclusão, disponível no programa NIS Elements BR 3.1; que foi alocado sobre a imagem na tela do computador. Todas as células que tocavam a linha de inclusão e com nucléolo evidente foram consideradas, assim como aquelas que se encontravam dentro do sistema teste de pontos. Dessa forma, o programa contou e mediu todos os hepatócitos manualmente apontados e circulados nos diferentes 
campos, realizando e salvando a contagem de núcleos e a medição de área celular $\left(\mu \mathrm{m}^{2}\right)$ a partir das lâminas histológicas.

Assim como para a contagem de núcleos, para a medida celular também foram analisados 3 animais por grupo, dos quais foram feitas 5 lâminas com 3 cortes cada. Em cada corte foram analisadas 10 células em 5 campos aleatórios, totalizando uma análise de 2250 células por grupo experimental. A intensidade de coloração da marcação com PAS foi medida (pixels) pelo software Image $J$ (NIH, Bethesda, MD, EUA).

\subsection{ESTIMATIVA DO CONTEÚDO DE GLICOGÊNIO HEPÁTICO}

A determinação do conteúdo de glicogênio hepático foi realizada a partir de modificações na metodologia previamente descrita por Hassid et al., (1957).

Brevemente, amostras de tecido ( $300 \mathrm{a} 500 \mathrm{~g}$ ) foram lavadas três vezes com PBS frio e hidrolisadas por adição de $0,2 \mathrm{~mL}$ de $\mathrm{Na}_{2} \mathrm{SO}_{4}$ saturado à $40 \%$ e $4,5 \mathrm{~mL}$ de etanol absoluto durante 15 segundos (s) à $60^{\circ} \mathrm{C}$ e então, centrifugadas por $15 \mathrm{~min}$ a $1.200 \mathrm{~g}$. Depois da centrifugação, o pellet foi seco à temperatura ambiente e ressuspenso em água destilada à $80^{\circ} \mathrm{C}$. Essa última etapa foi repetida para garantir a precipitação de todo o conteúdo de glicogênio da amostra e o precipitado foi submetido a diluições seriadas em volume conhecido de água destilada. A concentração do glicogênio foi lida no espectrofotômetro (Gene Quant, Amersham Pharmacia Biotech, Amersham, Reino Unido) à $490 \mathrm{~nm}$. Todos os valores obtidos para a concentração de glicogênio hepático foram normalizados pela curva padrão de glicose e diluições e, por fim, expressos em mg de glicogênio por $100 \mathrm{mg}$ de tecido hepático em relação ao peso da alíquota analisada.

\subsection{ANÁLISE ESTATÍSTICA}

Os resultados apresentados foram expressos como média \pm erro padrão da média (EPM). Os testes de análise de variância (ANOVA de uma ou duas vias), ocasionalmente teste $T$ student e testes Kruskal-Wallis ou Mann-Whitney $U$ foram realizados após avaliação da normalidade dos dados (Kolmogorov-Smirnov) e então foram feitas as comparações estatísticas entre os grupos. 
Foram utilizados, quando aplicáveis, os pós-testes de Bonferroni ou Dunnett's em dados paramétricos e Duns's Multiple Comparison Test em dados não paramétricos (GraphPad software, San Diego, CA, EUA). Em todos os resultados se adotou $5 \%$ como limite de significância estatística $(p<0,05)$. 


\section{RESULTADOS}

\subsection{EFEITOS DA PINEALECTOMINA SOBRE NÍVEIS DE MELATONINA}

A pinealectomia indubitavelmente diminui os níveis circulantes de melatonina, como indica a dosagem de 6-sufatoxi-melatonina na urina dos grupos CTL e PINX (Figura 7):

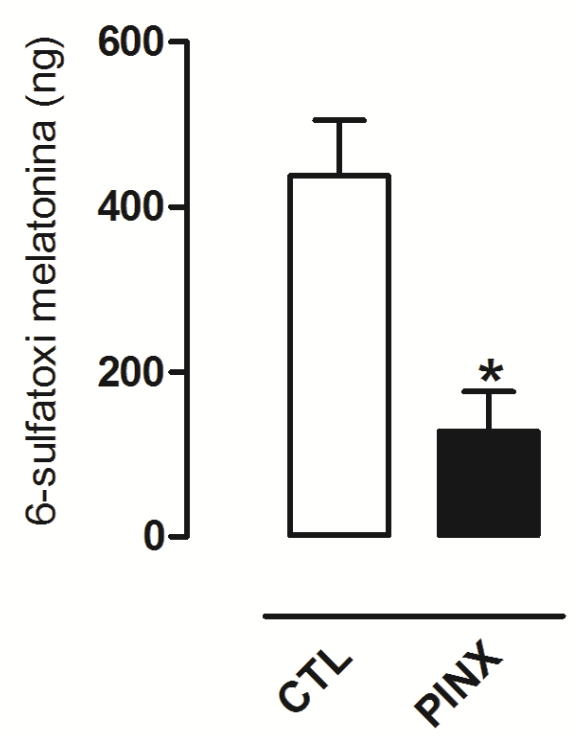

Figura 7: Níveis de 6-sufatoxi-melatonina na urina de animais nas condições CTL e PINX dosados durante 14h de período noturno, ${ }^{*} \mathrm{p}<0,05$ vs. CTL. $\mathrm{n}=8$ /grupo.

\subsection{EFEITOS DA PINEALECTOMINA SOBRE NÍVEIS GLICÊMICOS E HORMONAIS}

Os níveis glicêmicos observados ao longo de 8 ZTs num único dia, igualmente distribuídos entre as fases de claro e escuro, mostraram aumento no ZT 18 e tendência a aumento da glicose circulante em PINX em quase todos os pontos analisados com pequena inversão deste padrão no ZT 12, em que o nível glicêmico de PINX é menor em relação ao CTL, sendo este, período transicional entre a fase clara e escura (Figura $8 \mathrm{~A}$ ).

Da mesma forma, os níveis insulinêmicos são mais baixos em animais PINX, no período de transição entre a fase clara e a fase escura, aproximadamente entre os ZTs 9 e 15 (Figura 8 B). Interessantemente, no período do fim da fase clara, é 
quando ocorrem os maiores níveis circulantes de corticosterona em PINX, no ZT 9 e 12 (Figura $8 \mathrm{C}$ ).
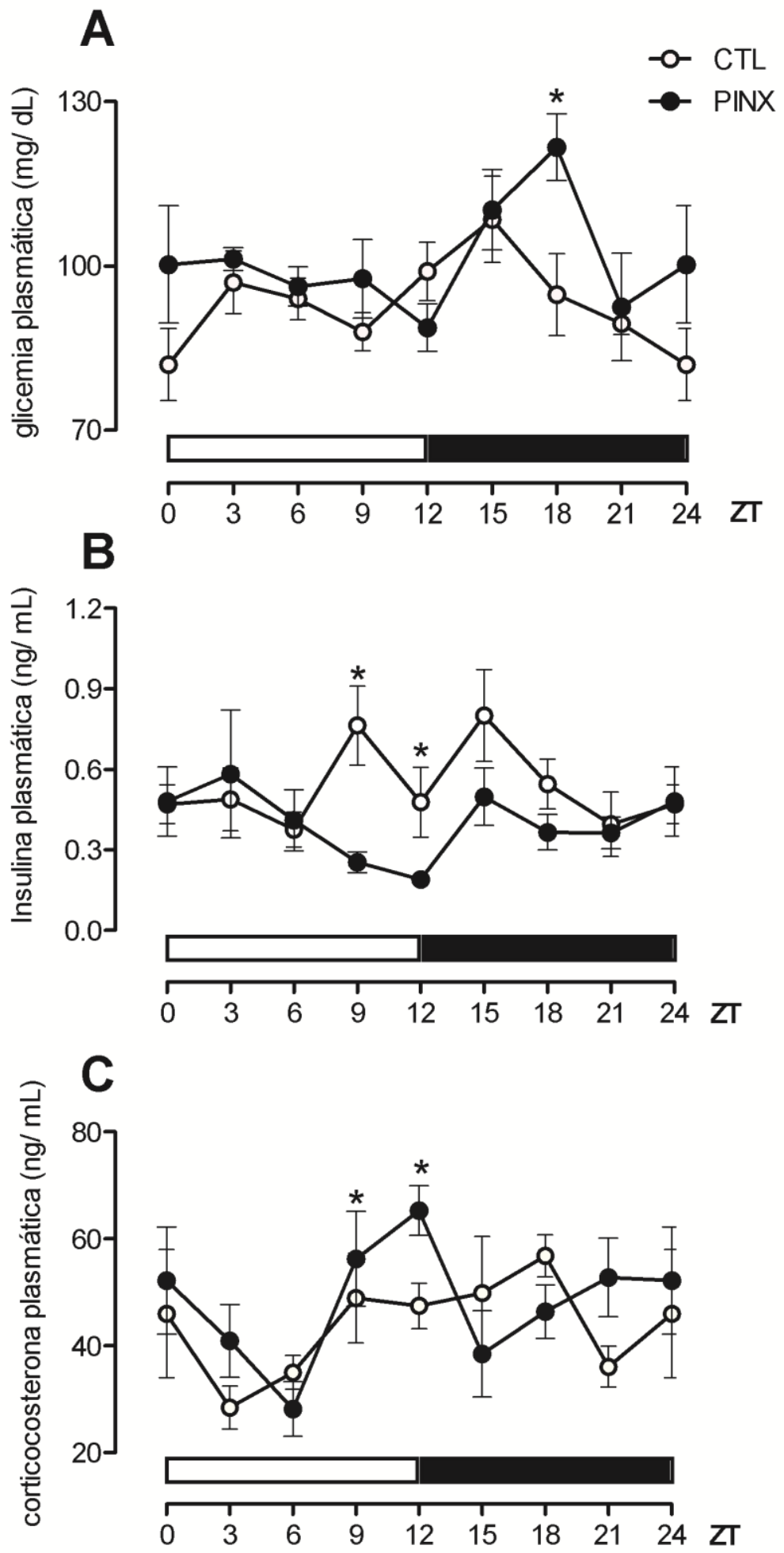

Figura 8: A. Níveis de glicemia (A), insulina plasmática (B) e corticosterona plasmática (C) em animais CTL e PINX ao longo de 8 ZTs num único dia. Os valores são resultados das médias +/- os erros padrões. * $p<0,05$ vs. CTL. $n=4 / g r u p o / Z T$. 
4.3 EFEITOS DA RETIRADA DA GLÂNDULA PINEAL E DO BLOQUEIO FARMACOLÓGICO DA SINALIZAÇÃO DO RECEPTOR DE GLICOCORTICÓIDES SOBRE O METABOLISMO ENERGÉTICO NO ZT 10

\subsubsection{EFEITOS DA PINEALECTOMINA E DO BLOQUEIO FARMACOLÓGICO DA SINALIZAÇÃO DO RECEPTOR DE GLICOCORTICÓIDES SOBRE NÍVEIS GLICÊMICO E HORMONAIS}

No ZT 10, a insulina basal observada tende a ser menor em PINX e revertida a níveis equivalentes aos encontrados no grupo CTL em animais PINX RU (Figura 9 B). A glicemia não apresenta diferença relevante entre os grupos estudados (Figura 9 A), embora haja aumento dos níveis de corticosterona plasmática em PINX no período (Figura $9 \mathrm{C}$ ).

A

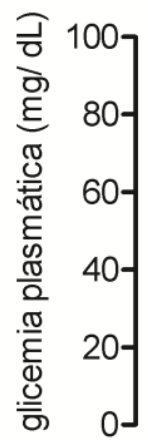

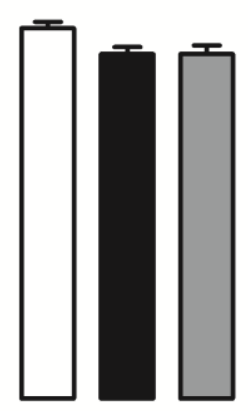

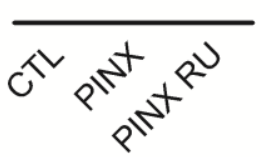

B

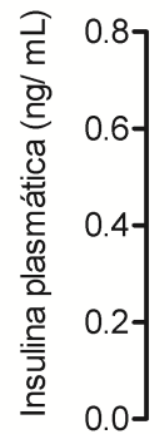

0.0
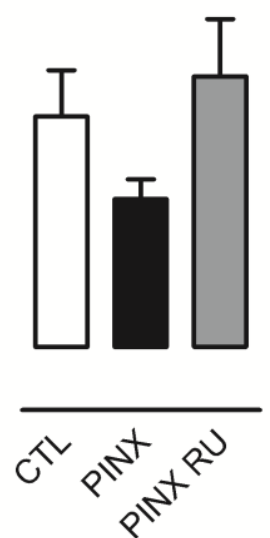

C
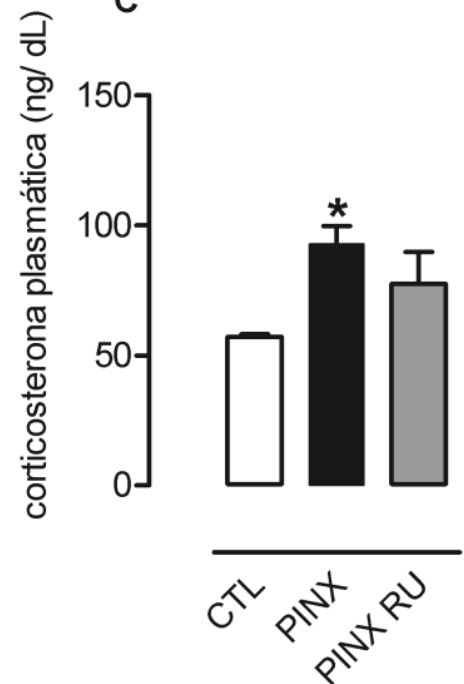

Figura 9: Glicemia plasmática (A), insulinemia (B) e corticosterona plasmática (C) no ZT 10 nas condições CTL, PINX e PINX RU. Os valores são resultados das médias $+/$ - os desvios padrões, ${ }^{*} p<0,05$ vs. $C T L, n=12 / g r u p o$ (A), $n=7 /$ grupo (B) e $n=4 /$ grupo $(C)$.

\subsubsection{MORFOMETRIA}

A análise morfométrica apontou diminuição da porcentagem relativa de adiposidade periabdominal em animais PINX, que retoma a valores estatisticamente semelhantes aos do grupo CTL após tratamento com RU 486 (Figura 10 a e Figura 11 A). Já a porcentagem de massa muscular parece diminuir em PINX, 
indiferentemente do bloqueio farmacológico do receptor de glicocorticóides com RU 486 (Figura $10 \beta$ e 11 B). A densitometria óssea dos animais não apresentou diferença entre grupos experimentais (Figura 10 y e Figura $11 \mathrm{C}$ ).

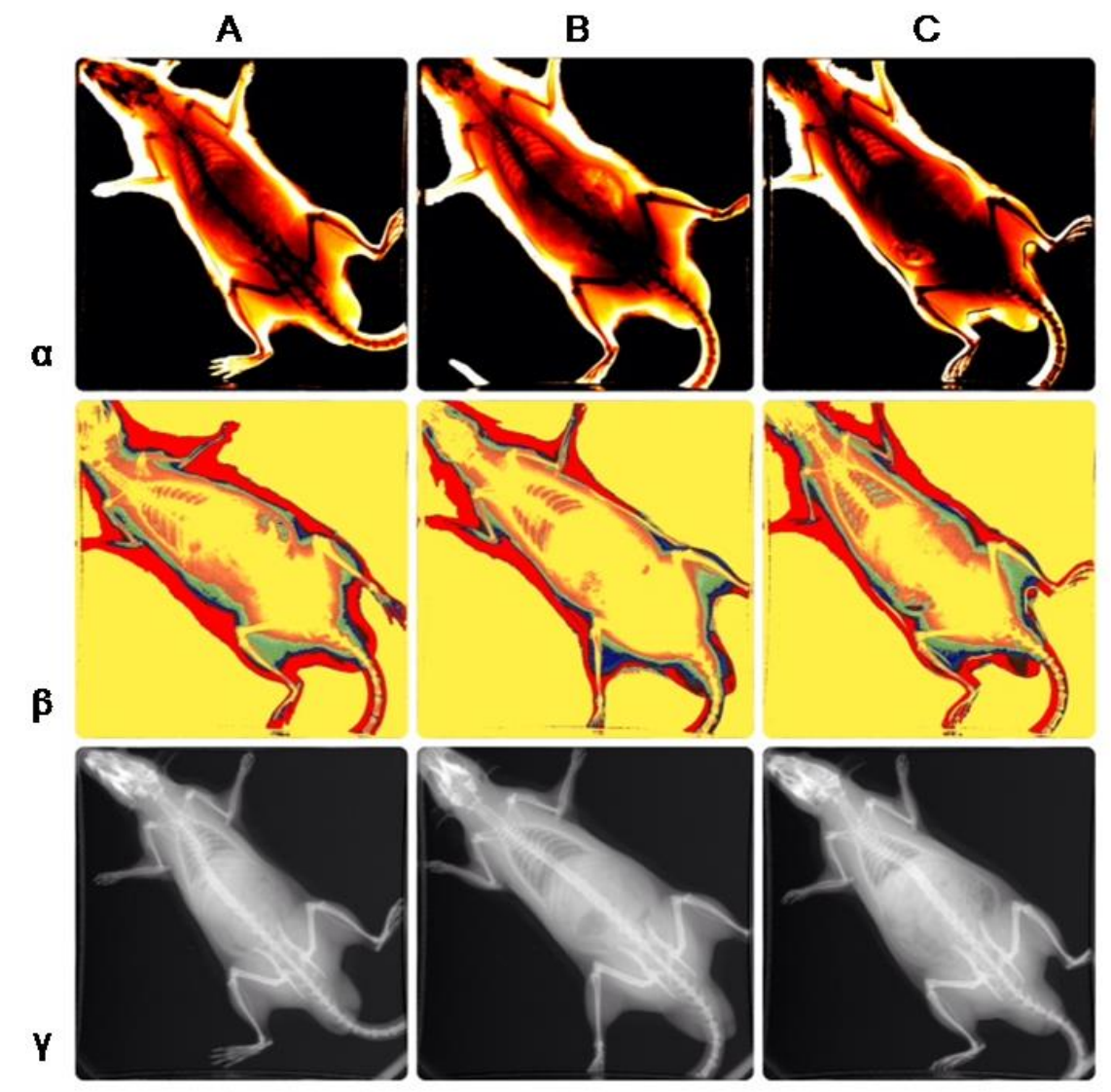

Figura 10: Composição corpórea por sistema de imageamento in vivo FX PRO. $\alpha$. Adiposidade abdominal, $\beta$. Massa muscular, y. Densidade óssea. A: CTL; B: PINX; C: PINX RU, n=4/grupo.
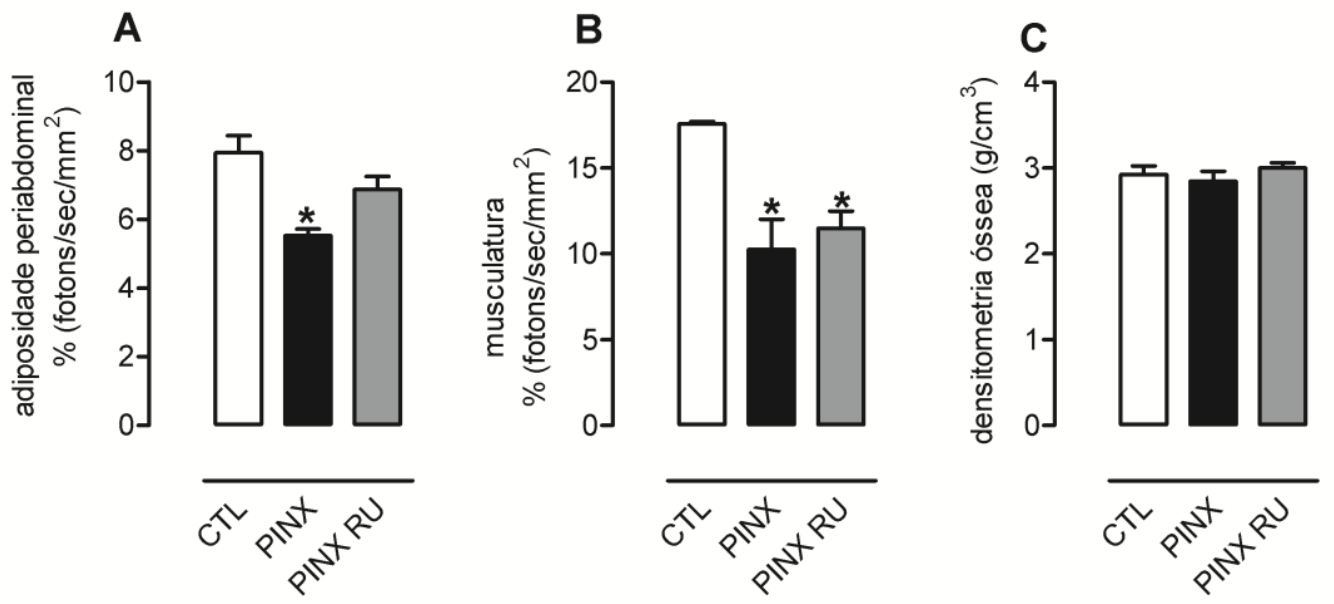

Figura 11: As análises morfométricas por sistema de imageamento in vivo da adiposidade periabdominal $(A)$, da massa muscular (B) e da densitometria óssea (C); nas condições CTL, PINX e PINX RU, * $p<0,05$ vs. CTL. $\mathrm{n}=4$ /grupo. 
O levantamento do peso corpóreo unitário indicou que, após 30 dias transcorridos da cirurgia de pinealectomia houve perda de peso em animais PINX, em relação aos demais grupos (Figura 12 A). Já o peso do fígado (Figuras 12 B) e o peso do tecido adiposo epididimal (Figuras $12 \mathrm{C}$ ), mensurados por pesagem direta dos órgãos não mostrou diferença entre os grupos.

A

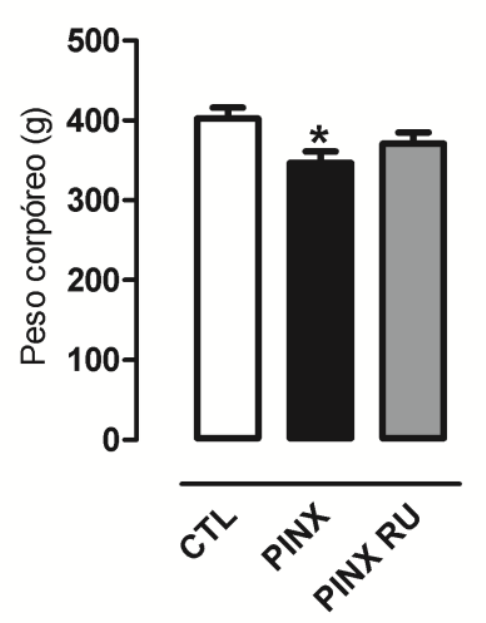

B

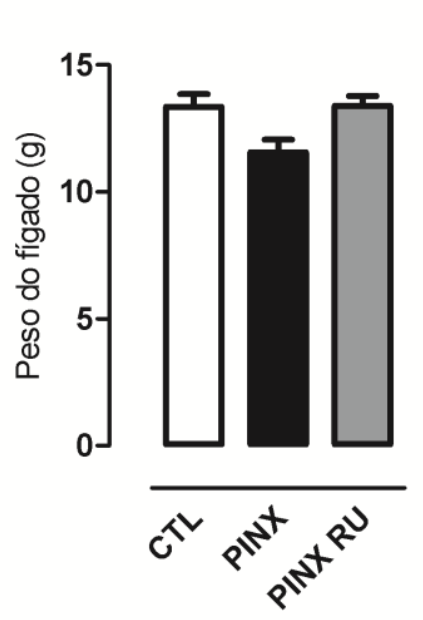

C

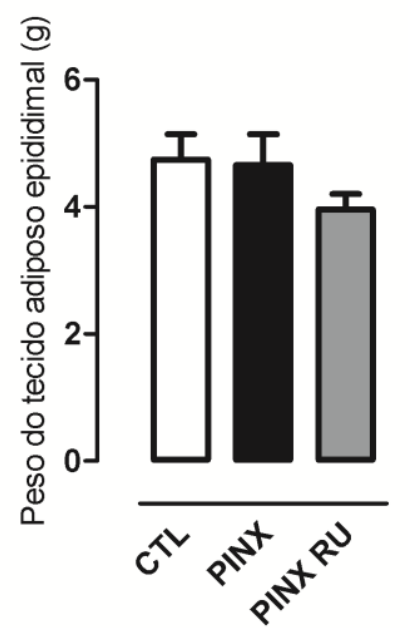

Figura 12: Pesos em gramas (g) de ratos Wistar machos utilizados nos experimentos 30 dias após cirurgia de pinealectomia e tratamento. A. Peso corpóreo unitário. B. Peso do fígado e C. Peso do tecido adiposo epididimal; nas condições CTL, PINX e PINX RU, * $p<0,05$ vs. CTL. $n=20 /$ grupo (A) e $n=8 /$ grupo (B, C).

\subsubsection{TESTES FUNCIONAIS IN VIVO DE TOLERÂNCIA E SENSIBILIDADE À GLICOSE E AO PIRUVATO}

Os ensaios funcionais realizados para averiguar tolerância à glicose (ip.GTT) e estimar a taxa de gliconeogênese, através do teste de tolerância ao piruvato (ip.PTT) mostraram tendência a intolerância à glicose e ao piruvato em animais PINX em relação ao CTL. O tratamento com $R U$ 486, no entanto, reverteu tais efeitos, porém de maneira significativa apenas no ip.PTT. (Figura 13 A e 13 B). 

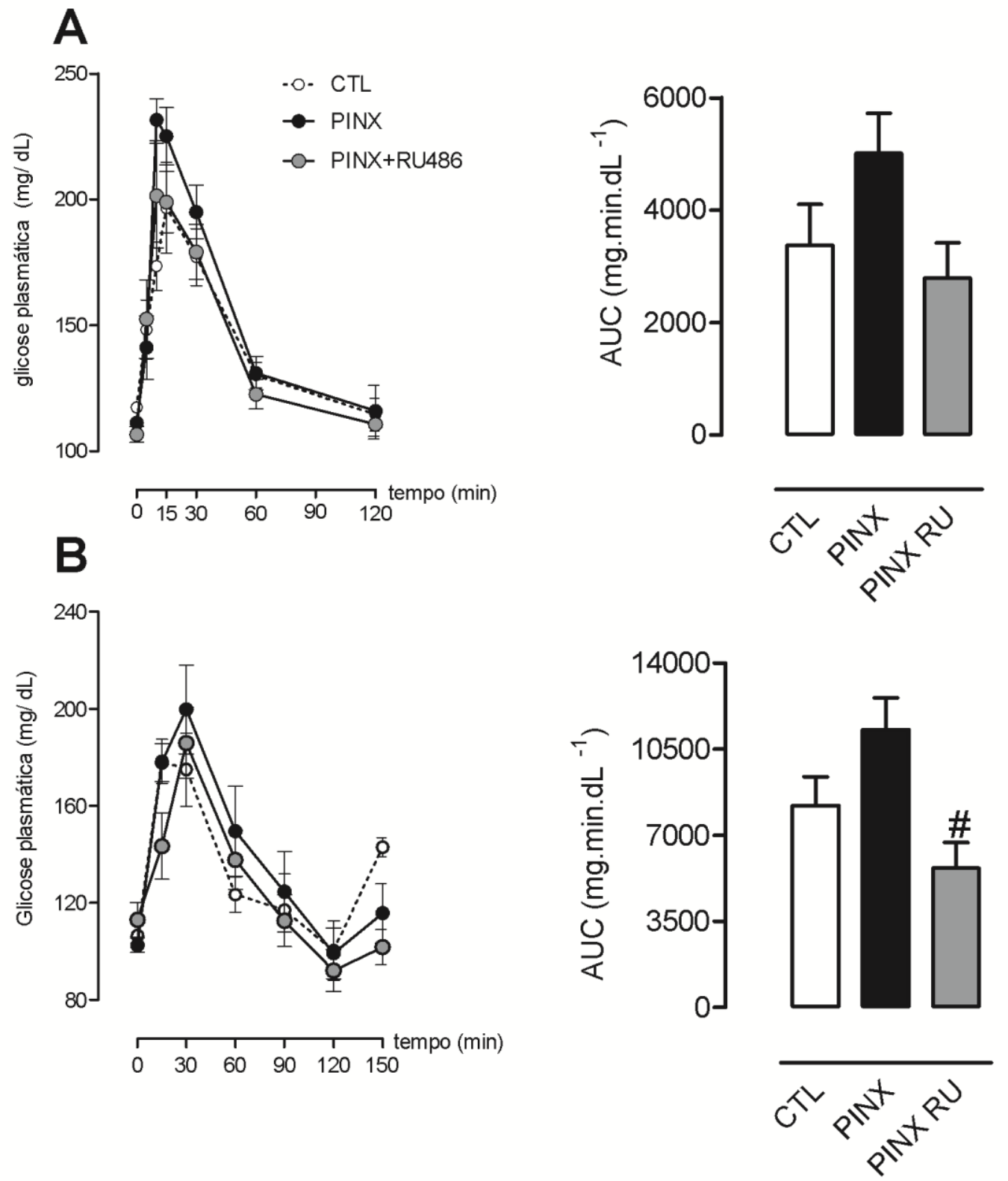

Figura 13: Variação da glicemia após injeção ip. de glicose $(A)$ e piruvato $(B)$; à direita o gráfico na área sob a curva. Os experimentos foram realizados nos grupos experimentais CTL, PINX e PINX RU. Os valores são resultados das médias +/- os erros padrões, \#p<0,05 vs. PINX, $n=8 /$ grupo (A) e $n=9 /$ grupo (B).

\subsubsection{ANÁLISES DE SECREÇÃO ESTÁTICA DE INSULINA EM ILHOTAS PANCREÁTICAS}

A secreção de insulina pelas ilhotas pancreáticas foi maior em PINX em todas as concentrações avaliadas, enquanto que PINX RU não varia em relação ao grupo CTL (Figura 14). 


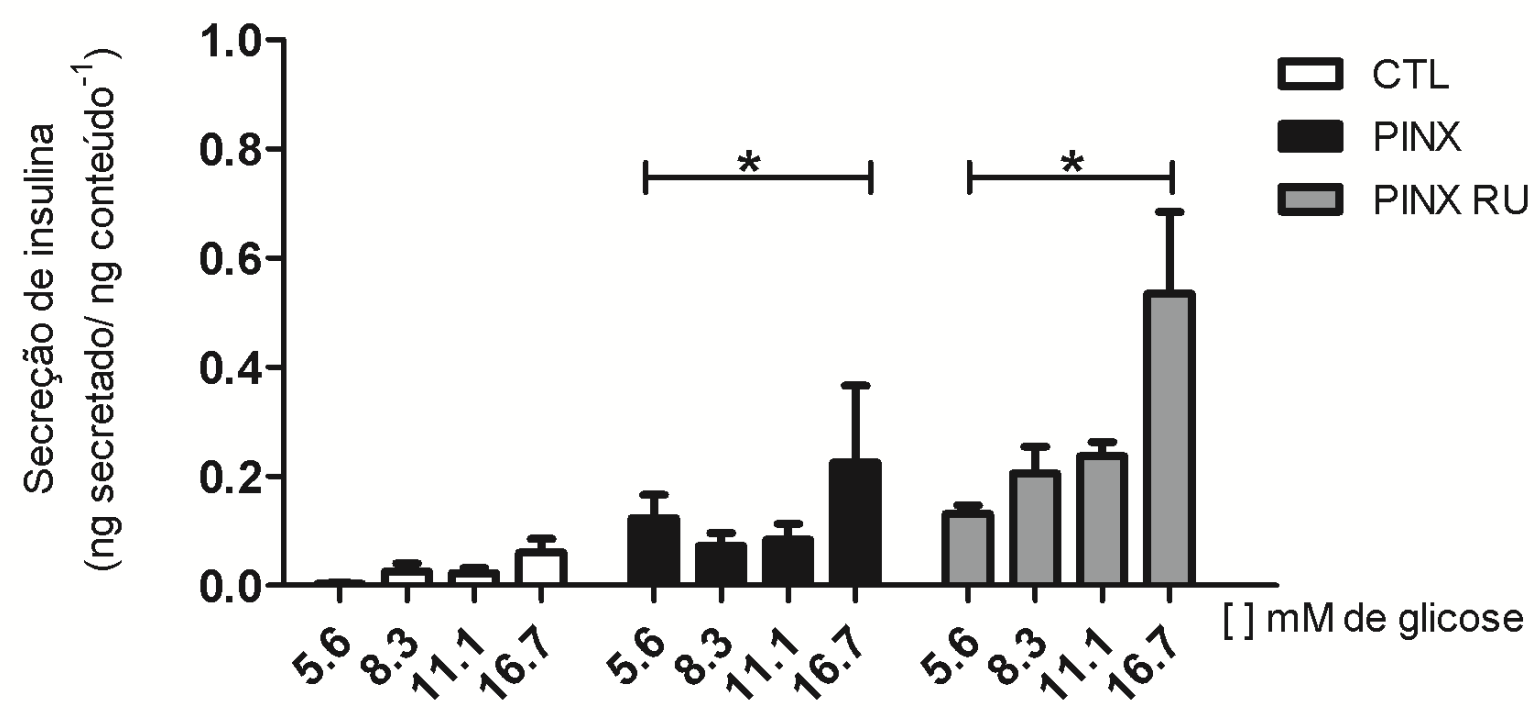

Figura 14: secreção estática de insulina por ilhotas pancreáticas isoladas, nas concentrações 5.6, 8.3, 11.1 e 16.7 mM dos grupos experimentais CTL, PINX e PINX RU. Os valores são resultados das médias +/- os erros padrões, ${ }^{*} p<0,05$ vs. CTL, $n=3 /$ grupo.

\subsubsection{LIPÍDEOS CIRCULANTES}

A quantificação de lipídeos circulantes no plasma não mostrou variação nos níveis de colesterol total (Figura $15 \mathrm{~A}$ ), porém houve aumento nos níveis de colesterol LDL em PINX RU (Figura 15 B). Ocorreram diminuições significativas das triglicérides no plasma em ambos os grupos pinealectomizados (Figura $15 \mathrm{C}$ ).
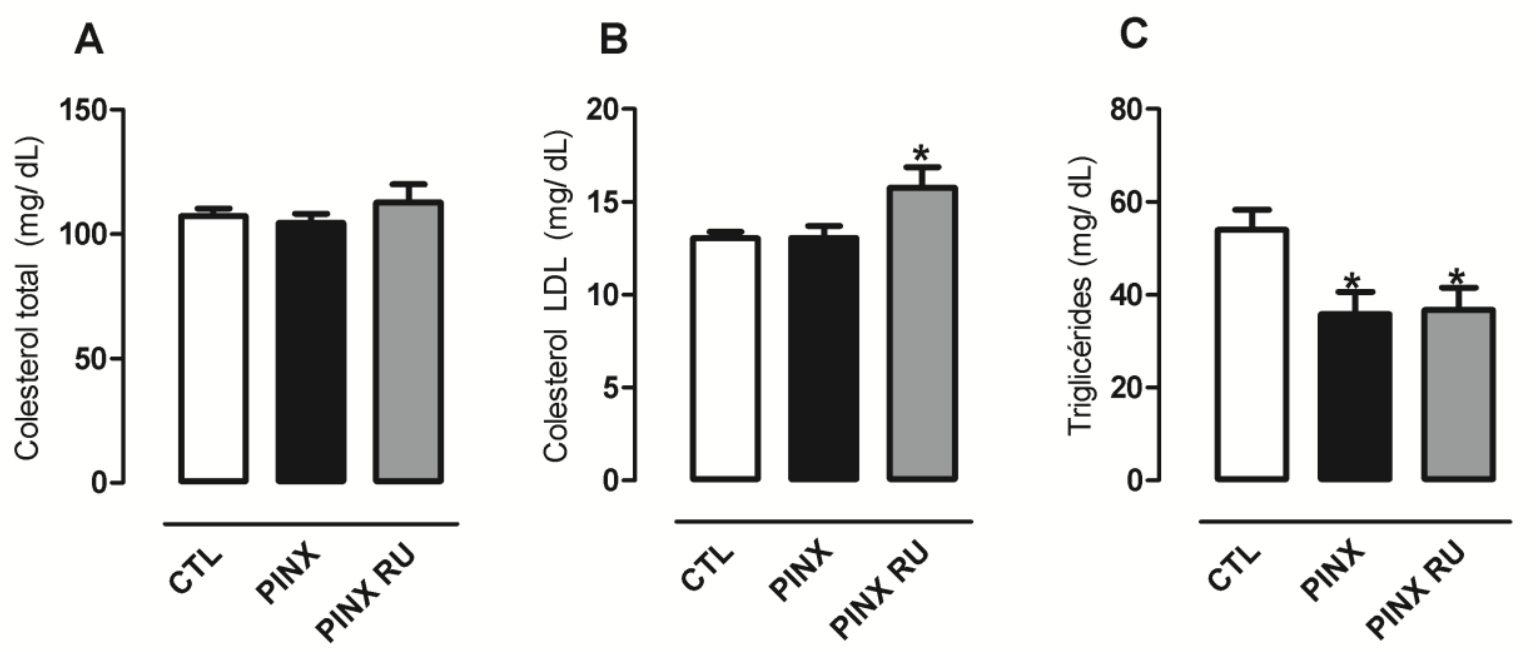

Figura 15: Dosagem de colesterol total $(A)$, colesterol LDL $(B)$ e triglicérides $(C) \mathrm{em} \mathrm{mg} / \mathrm{dL}$ no soro de animais CTL, PINX e PINX RU. Os valores são resultados das médias +/- os erros padrões * $p<0,05$ vs. $C T L, n=7 / g r u p o$. 


\subsubsection{RESPOSTA DE FOSFORILAÇÃO DA AKT HEPÁTICA APÓS ESTÍMULO COM INSULINA}

A fosforilação em serina da AKT no fígado, normalizada por $\beta$ actina, apresentou resposta aumentada à insulina em CTL após estímulo com o hormônio; diminuição da fosforilação da AKT em animais PINX nas condições estimulada e não estimulada, evidenciando a baixa responsividade hormonal à insulina em PINX; e, alta fosforilação basal e ausência de responsividade à insulina após estímulo nos animais tratados com RU 486 (Figura 16).

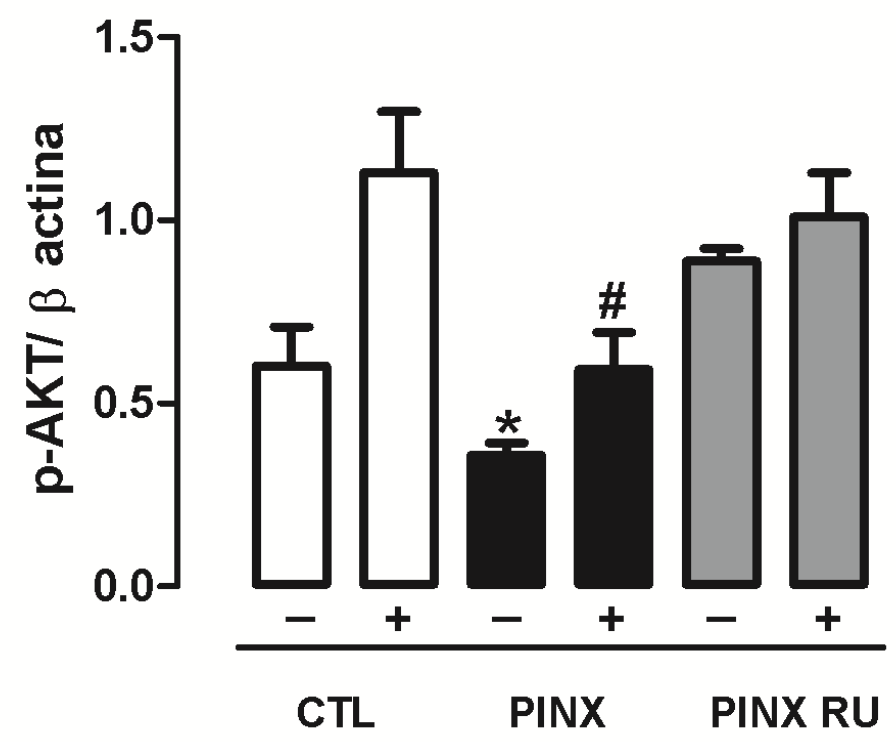

Figura 16: Imunoblotting para fosforilação em serina da AKT normalizados pela $\beta$ actina após estímulo com insulina (+) e na sua ausência (-), nas condições CTL, PINX e PINX RU. Os valores são resultados das médias no tecido hepático $+/$ - os erros padrões * $p<0,05$ vs. CTL-, \# $p<0,05$ vs. CTL+, $n=6 /$ grupo.

\subsubsection{ALTERAÇÃO DOS NÍVEIS PROTÉICOS E DE TRANSCRIÇÃO DE RNAm DE PROTEÍNAS HEPÁTICAS RELACIONADAS À SINALIZAÇÃO DO RECEPTOR DE GLICOCORTICÓIDES}

O receptor de glicocorticóides (GR) apresentou diminuição de seu conteúdo protéico em hepatócitos de animais PINX RU e tendência à diminuição da expressão de seu RNAm também, comparativamente aos demais grupos experimentados (Figura 17 A e B). O conteúdo protéico da enzima $11 \beta$ HSD1, por outro lado, apresentou aumento em PINX e menores valores em PINX RU (Figura $17 \mathrm{C}$ ) 
enquanto que nenhuma alteração foi observada na expressão relativa de seu RNAm (Figura 17 D) ou mesmo nos níveis protéicos e de RNAm de DexRas (Figura 17 E e $\mathrm{F})$.

A
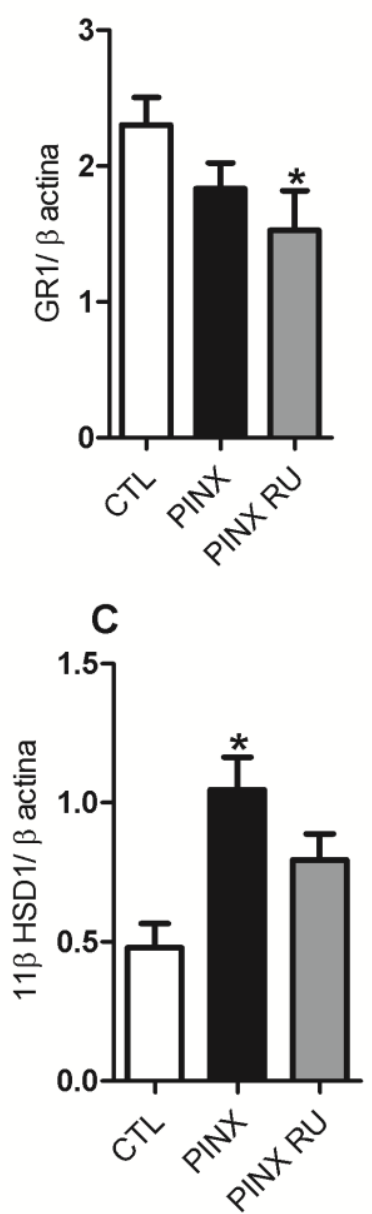

E

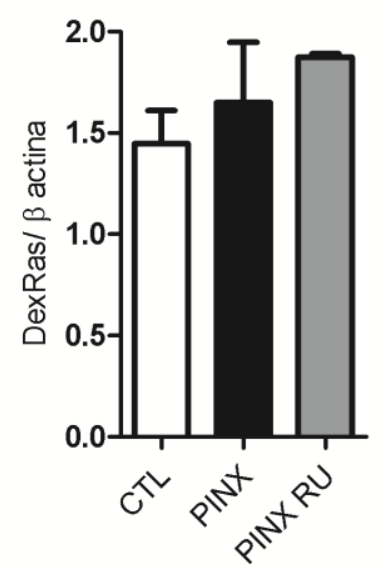

B
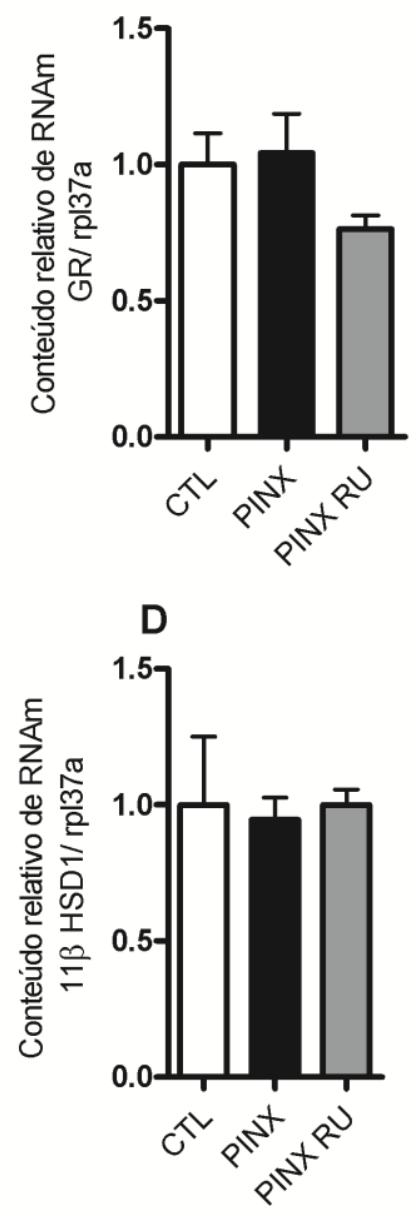

$\mathbf{F}$

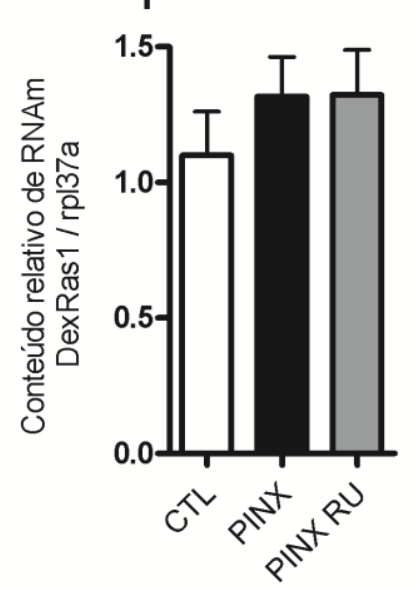

Figura 17: Conteúdo proteicos normalizados por $\beta$ actina e expressão relativa RNAm normalizados por Rpl37a respectivamente, de GR (A; B), 11ß HSD1 (C; D) e DexRas1 (E; F) nas condições CTL, PINX e PINX RU. Os valores são resultados das médias $+/$ - os erros padrões ${ }^{*} p<0,05$ vs. CTL., $n=6 /$ grupo ( $A, C, E$ ) e $n=4 /$ grupo (B, $D$, F). 


\subsubsection{CONTEÚdOS RELATIVOS DE RNAm HEPÁtICO PARA GENES ENVOLVIDOS NO METABOLISMO ENERGÉTICO}

Quanto à hexose-6-fosfato desidrogenase $(\mathrm{H} 6 \mathrm{pd})$, esta apresentou aumento hepático de seu conteúdo proteico em PINX (Figura 18 A) e de seu RNAm em PINX RU (Figura 18 B).

O transportador de glicose tipo II ou GLUT2 apresentou variações não significativas quanto ao conteúdo protéico, porém, a quantificação de seu RNAm mostrou aumento de expressão no tecido hepático de PINX RU (Figura. 18 C e D).
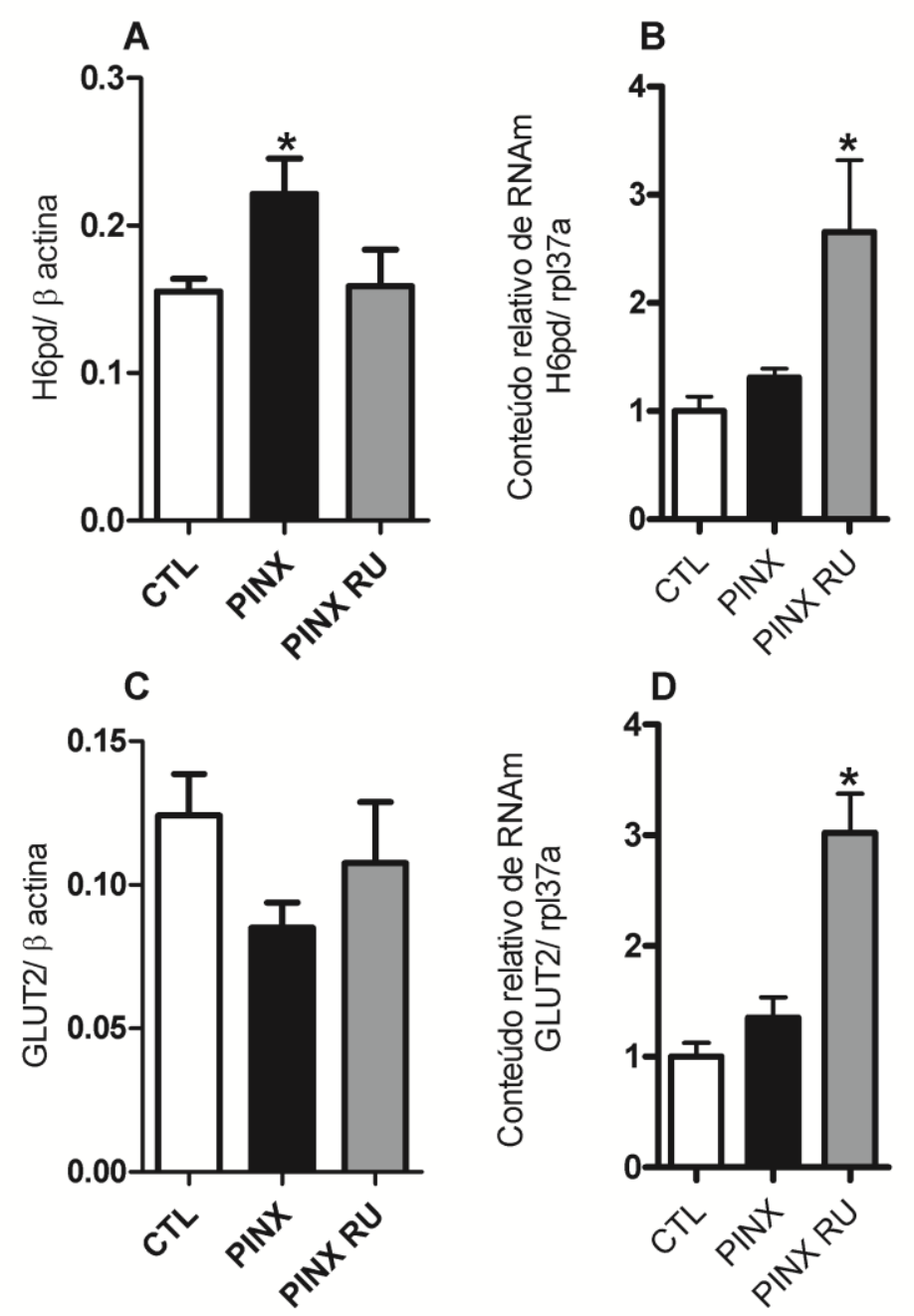

Figura 18: Conteúdos protéicos, normalizados por $\beta$ actina; e, expressão relativa RNAm normalizado por Rpl37a respectivamente, de H6pd (A; B) e GLUT2 (C; D) nas condições CTL, PINX e PINX RU. Os valores são resultados das médias $+/$ - os erros padrões * $p<0,05$ vs. $C T L, n=4$ /grupo $(A, B, D)$ e $n=8 /$ grupo (C).

PINX RU apresentou diminuição de expressão gênica relativa para fosfoenolpiruvato carboxiquinase (PCK-1) e glicose-6-fosfatase (G6pc), 
respectivamente (Figuras 19 A e B). No tecido hepático, a expressão relativa de Gys2- glicogênio sintase 2, mostra aumento significativo da expressão em PINX RU (Figura 19 C).

A

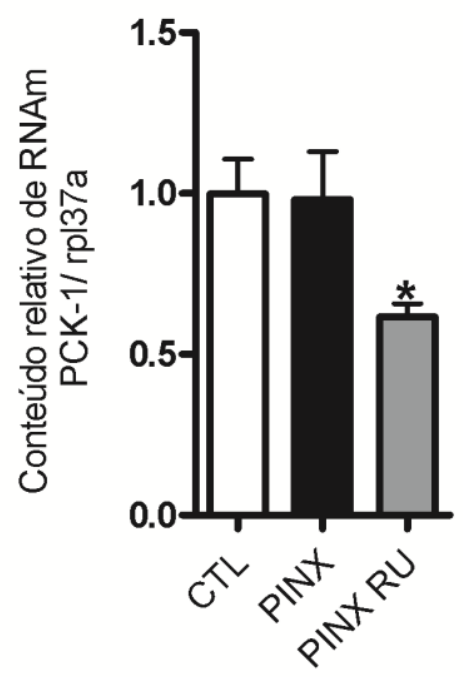

B

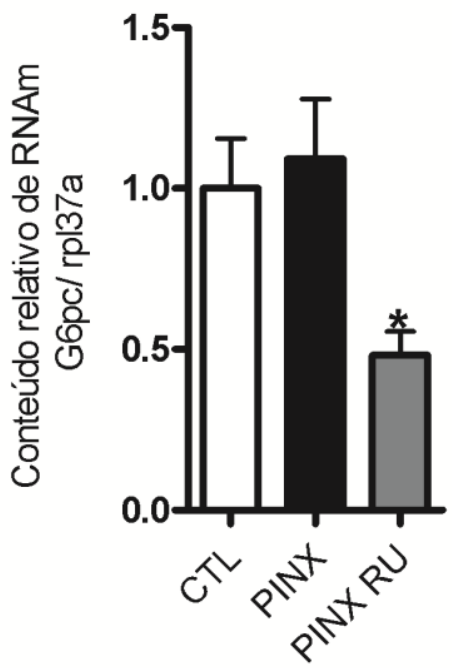

C

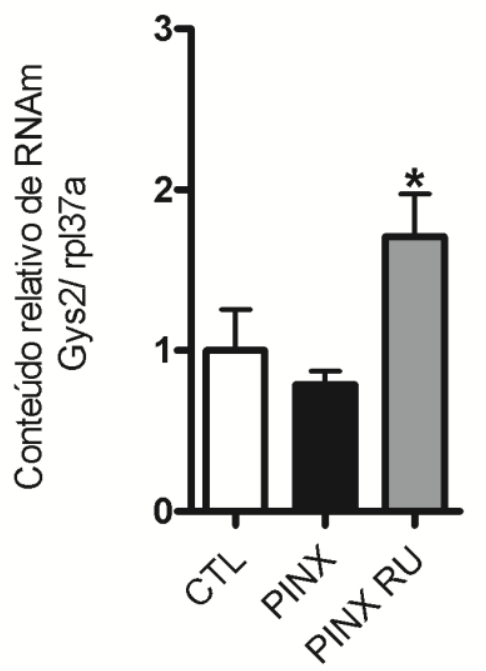

Figura 19: Quantificação hepática de mRNA de genes PCK-1 (A), G6pc (B) e Gys2 normalizados por Rpl37a nas condições CTL, PINX e PINX RU. Os valores são resultados das médias +/- os erros padrões * $\mathrm{p}<0,05$ vs. $C T L$, $n=4 /$ grupo $(A, B)$ e $n=6 /$ grupo $(C)$.

\subsubsection{CONTEÚDOS RELATIVOS DE RNAm HEPÁTICO PARA GENES ENVOLVIDOS NO METABOLISMO HEPÁTICO LIPÍDICO}

A expressão gênica relativa de acetil-coA-carboxiquinase (ACC $\alpha$ ) aumentou no fígado em PINX e PINX RU (Figura 20 A), assim como de enzima málica III- Me3 
(Figura 20 B). Em PINX, houve aumento da expressão das enzimas málicas I- Me1 (Figura $20 \mathrm{C}$ ) e II- Me2 (Figura 20 D), FAS N- sintase de ácidos graxos (Figura $20 \mathrm{E}$ ) e Dgat2- diacilglicerol acetiltransferase 2 (Figura $20 \mathrm{~F}$ ).

A
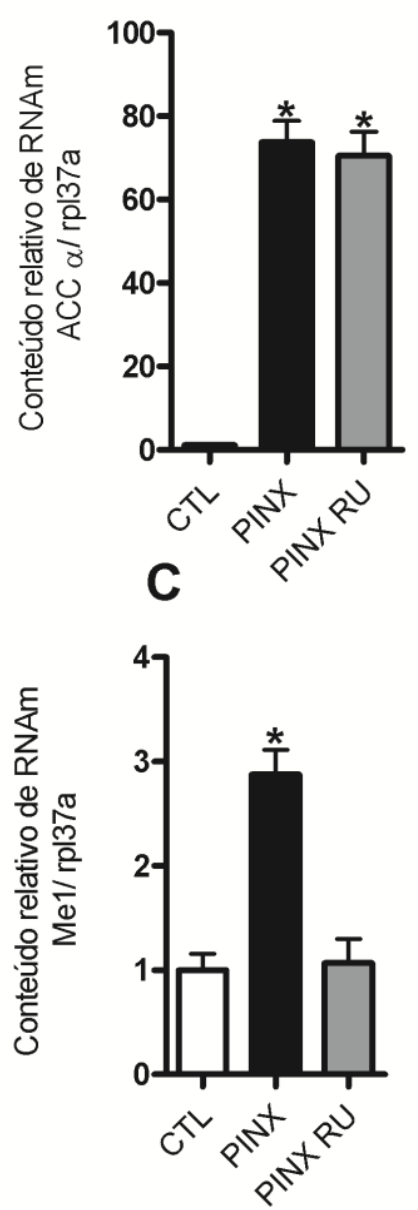

E

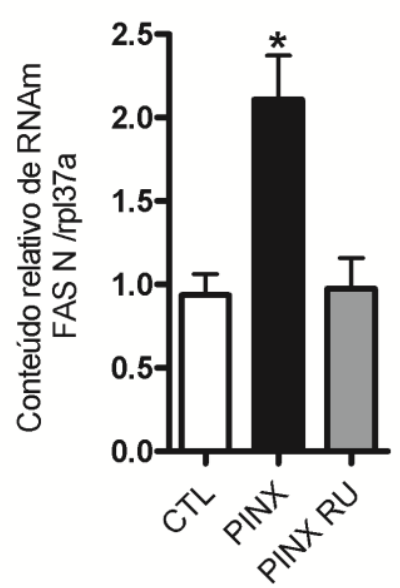

B
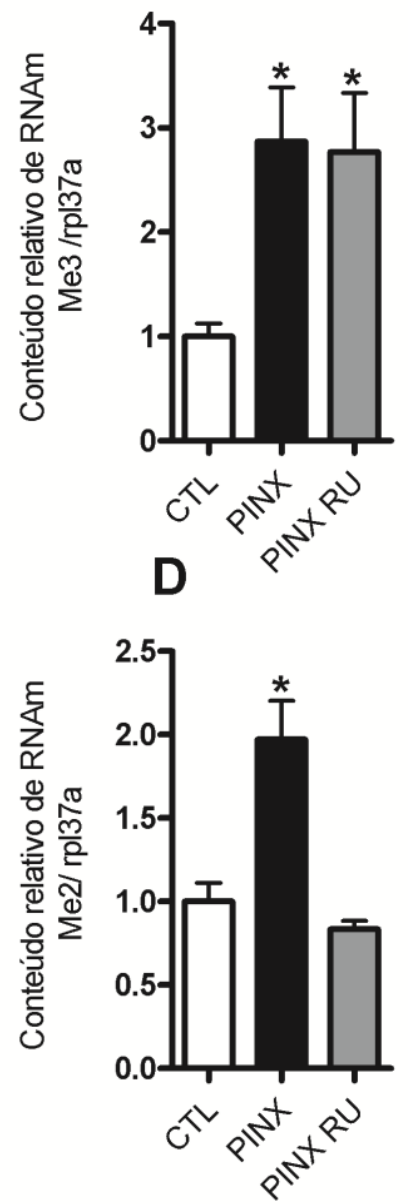

$\mathbf{F}$

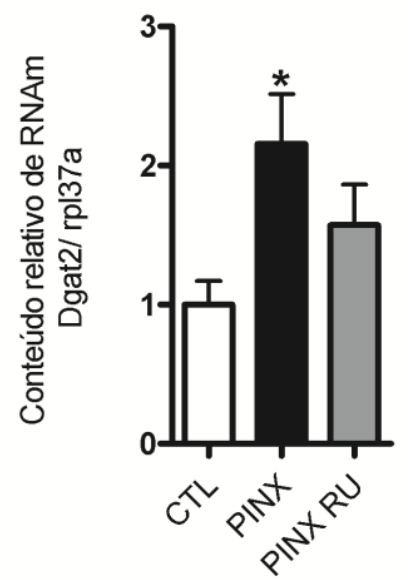

Figura 20: Expressão relativa RNAm de ACC a (A), Me3 (B), Me1 (C), Me2 (D), FAS N (E) e Dgat2 (F) normalizados por Rpl37a nas condições CTL, PINX e PINX RU. Os valores são resultados das médias +/- os erros padrões * $\mathrm{p}<0,05$ vs. CTL, $n=5 /$ grupo. 
Houve maior conteúdo relativo de RNAm em PINX para Mttp- microsomal triglyceride transfer protein (Figura $21 \mathrm{~A}$ ), Sec22b- vesicle trafficking protein homolog $B$ (Figura $21 \mathrm{~B}$ ), translocase de ácidos graxos FAT/CD36 (Figura 21 C) e LXRreceptores hepáticos $X$ (Figura $21 \mathrm{D}$ ).
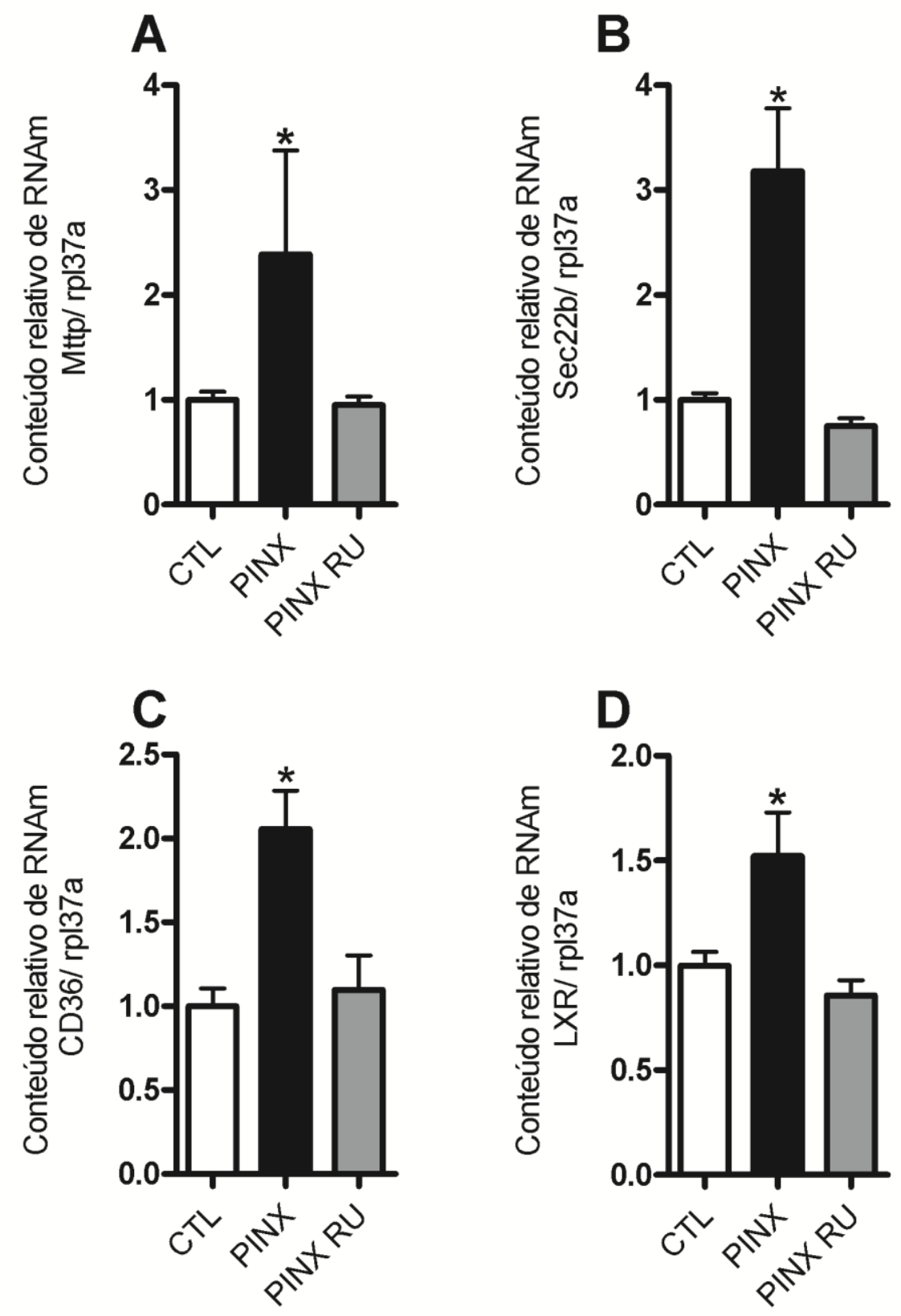

Figura 21: Expressão relativa RNAm de Mttp (A), Sec22b (B), CD36(C) e LXR (D) normalizados por Rpl37a nas condições CTL, PINX e PINX RU. Os valores são resultados das médias $+/$ - os erros padrões * $\mathrm{p}<0,05$ vs. CTL, $\mathrm{n}=6$ /grupo. 


\subsubsection{HISTOLOGIA HEPÁTICA}

A análise morfológica geral do tecido hepático pela coloração HematoxilinaEosina (H.E.) demonstrou diminuição da área celular $\left(\mu \mathrm{m}^{2}\right)$, analisada no aumento de 40X, em hepatócitos de ambos os grupos pinealectomizados, independente do tratamento com RU 486 (Figura $22 \mathrm{~A}, \mathrm{~B}$ e C e Figura $24 \mathrm{~A}$ ).

Em PINX, houve concomitante aumento do número de núcleos nas lâminas coradas com H.E. (Figura 24 B), indicando diminuição da área celular, porém sem a diminuição do número de células. No entanto, o grupo PINX RU mostrou contagem do número de núcleos semelhante à encontrada nas lâminas CTL (Figura $22 \mathrm{e}$ Figura 24 B), ou seja, a menor área celular em PINX RU é acompanhada de menor número de células viáveis no fígado.
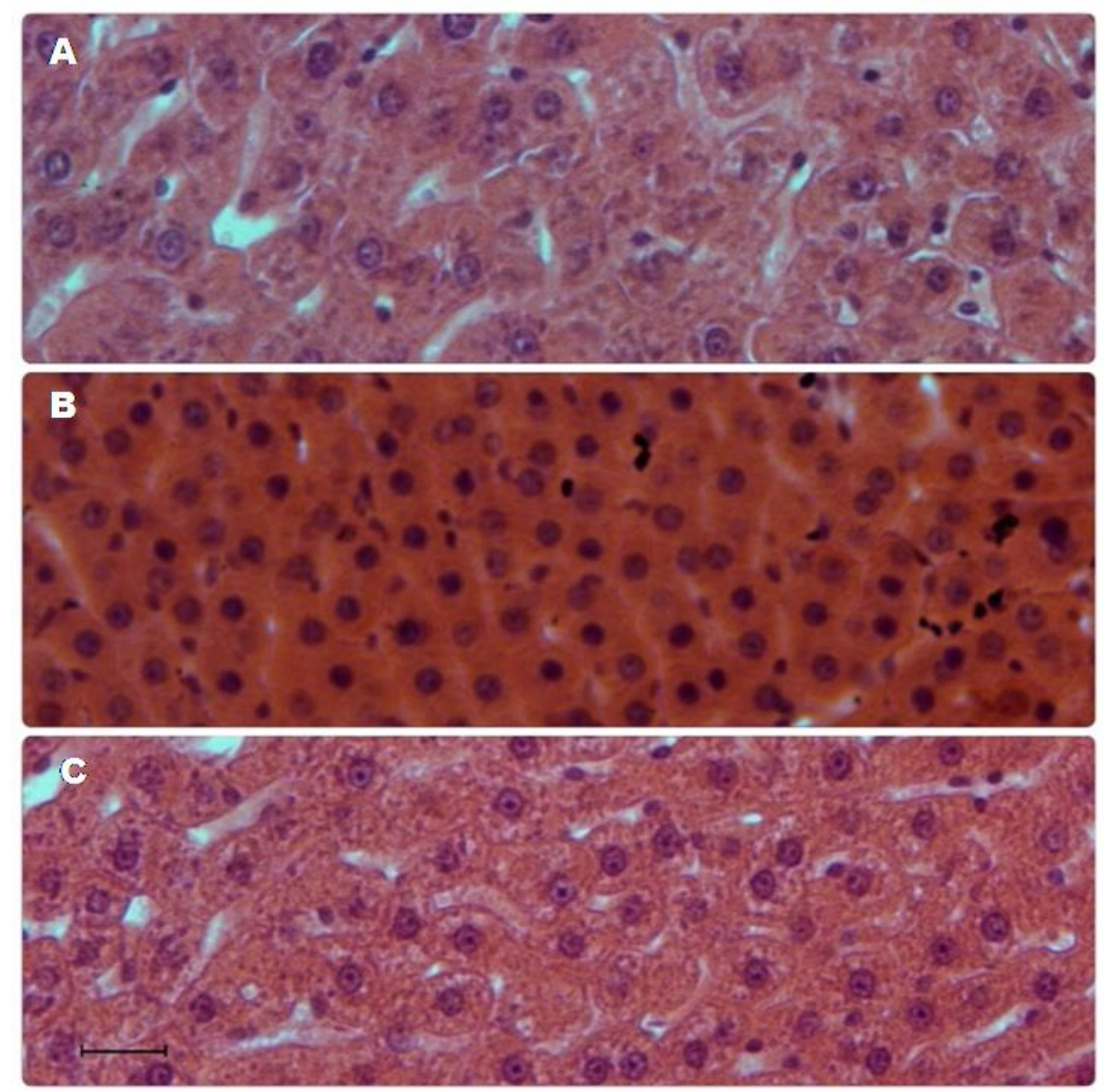

Figura 22: Histologia do tecido hepático. Coloração: Hematoxilina e eosina (H.E.); A: CTL; B: PINX e C: PINX RU. Barra de escala de $50 \mu \mathrm{m}, \mathrm{n}=225$ campos/grupo

A coloração por ácido periódico de Schiff (P.A.S.) indicou, através da maior intensidade de coloração, maior acúmulo de carboidratos estocados nos hepatócitos 
de PINX. No entanto, animais PINX RU apresentam o mesmo padrão de coloração visto no grupo CTL (Figura $23 \mathrm{~A}, \mathrm{~B}$ e C e Figura $24 \mathrm{C}$ ).

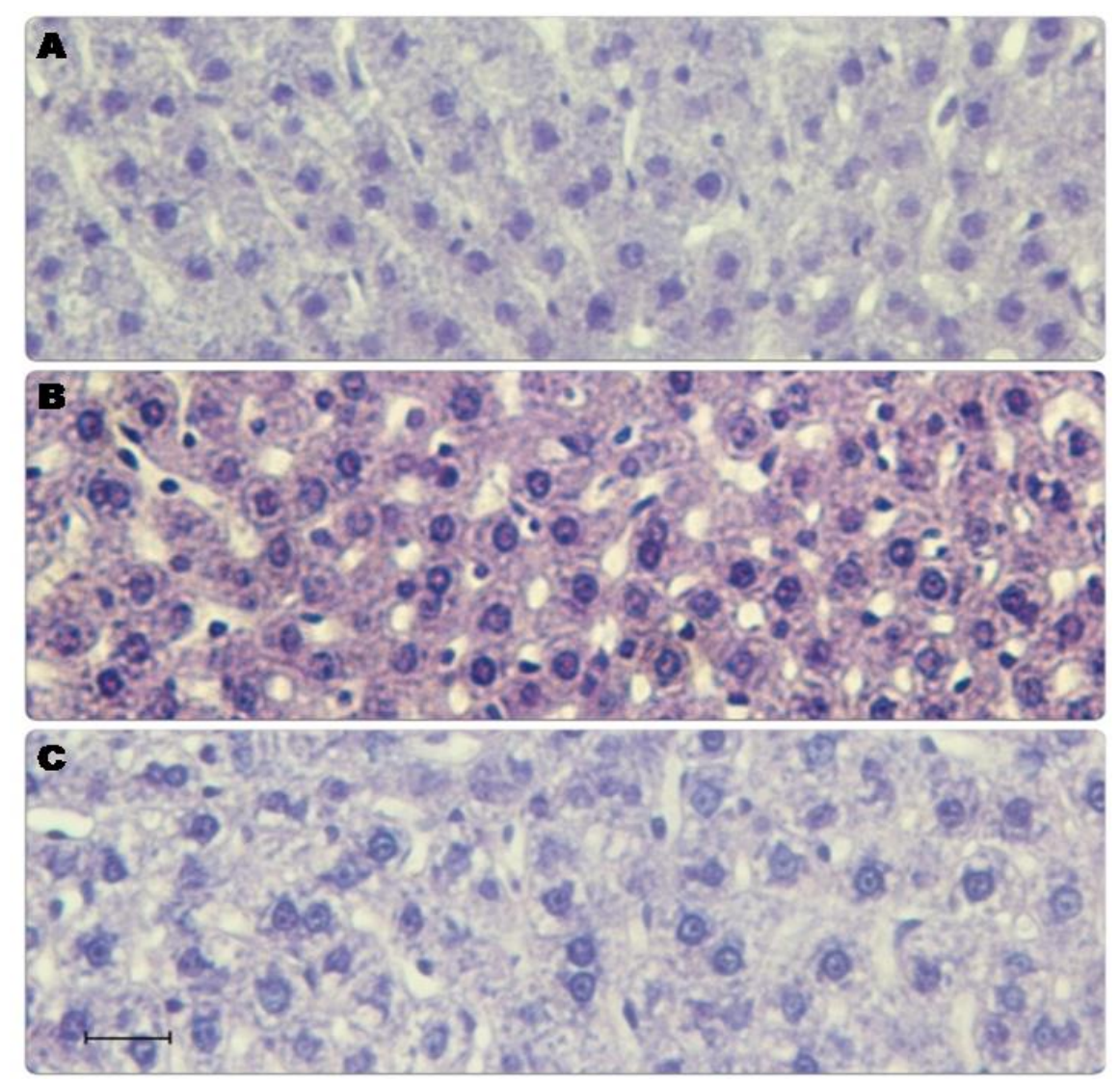

Figura 23: Histologia do tecido hepático. Coloração: Ácido Periódico de Schiff (P.A.S); A: CTL; B: PINX e C: PINX RU. Barra de escala de $50 \mu \mathrm{m}, \mathrm{n}=225$ campos/grupo.
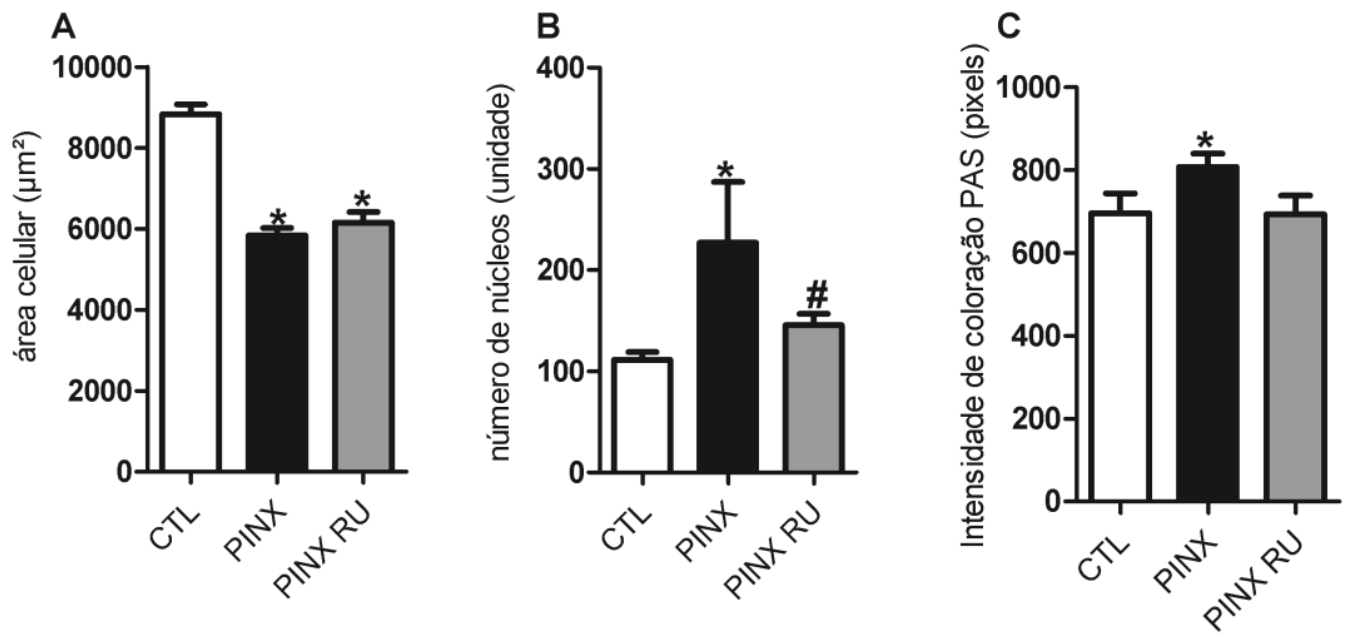

Figura 24: Análise da morfometria geral de hepatócitos por histologia. A. Área celular $\left(\mu m^{2}\right)$. B. Número de núcleos. C. Intensidade de coloração PAS em pixels das amostras analisadas, nas condições CTL, PINX e PINX $\mathrm{RU},{ }^{*} \mathrm{p}<0,05$ vs. CTL, $\# p<0,05$ vs. PINX. Aumento da análise: $40 X, \mathrm{n}=225$ campos/grupo. 


\subsubsection{GLICOGÊNIO HEPÁTICO}

Quanto ao glicogênio hepático no ZT 10, há maior estoque de glicose na forma de glicogênio no fígado de animais PINX (Figura 25).

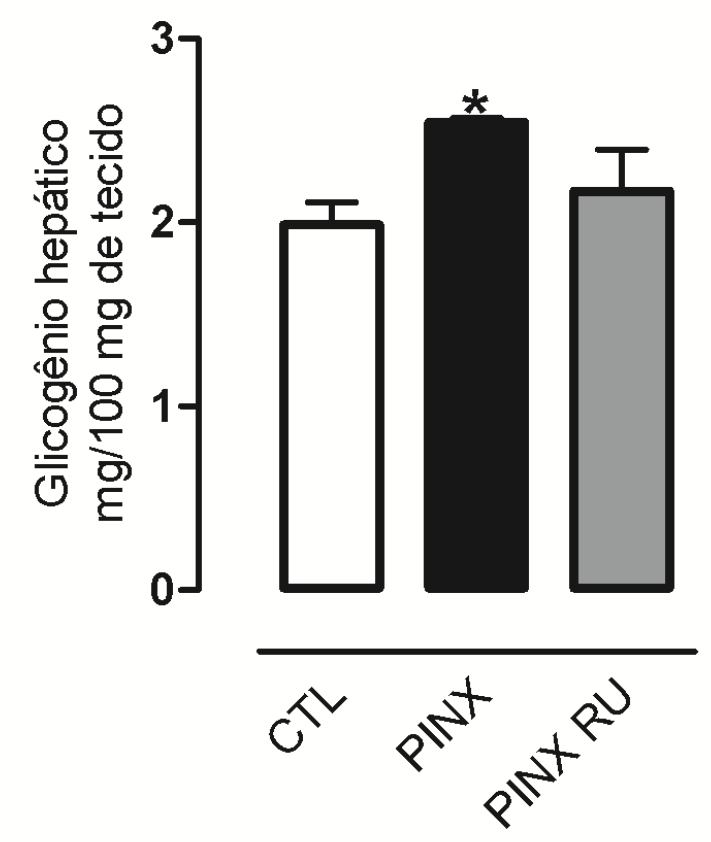

Figura 25: Conteúdo de glicogênio hepático, expresso por mg de glicogênio/ $100 \mathrm{mg}$ de tecido hepático, nas condições CTL, PINX e PINX RU. Os valores são resultados das médias +/- os erros padrões no ZT 10, ${ }^{*} p<0,05$ vs. CTL, $\mathrm{n}=5$ /grupo.

\subsection{EFEITOS DA RETIRADA DA GLÂNDULA PINEAL E DO BLOQUEIO FARMACOLÓGICO DA SINALIZAÇÃO DO RECEPTOR DE GLICOCORTICÓIDES SOBRE INFLAMAÇÃO HEPÁTICA NO ZT 10}

A expressão gênica de NF-kB aumenta nos fígados de PINX (Figura 26 A), assim como de IL1 RN, o antagonista do receptor de IL1 (Figura 26 F). Por outro lado, TNF a tem tendência à maior expressão gênica relativa em grupos pinealectomizados (Figura $26 \mathrm{~B}$ ); padrão semelhante ao observado quanto à mesmos resultados de IL1 a (Figura 26 C), IKK $\beta$ (Figura 26 D) e IL1 R1 (Figura 26 E), porém, estes têm aumento significativo apenas no grupo PINX RU. 

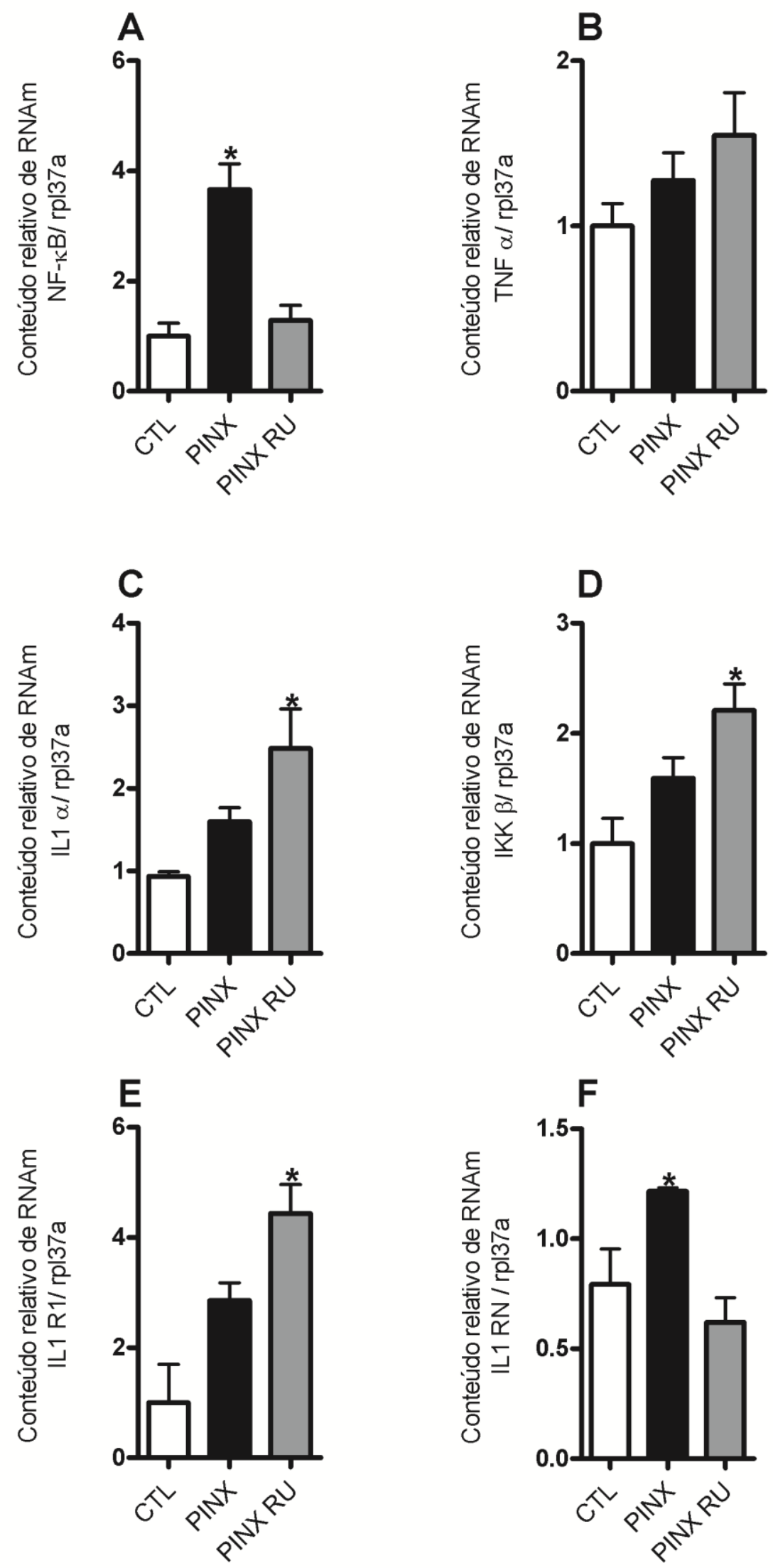

Figura 26: Quantificação hepática de mRNA de genes NF-KB(A), TNF $\alpha$ (B), IL1 $\alpha$ (C), IKK $\beta$ (D) IL1 R1 (E) e IL1 RN (F) normalizados por Rpl37a nas condições CTL, PINX e PINX RU. Os valores são resultados das médias +/os erros padrões * $\mathrm{p}<0,05$ vs. $\mathrm{CTL}, \mathrm{n}=5$ /grupo. 
A quantificação relativa de RNAm de NOS2 apresenta aumento em PINX e tendência a aumento em PINX RU (Figura 27 A) enquanto que conteúdo proteico de iNOS diminui em PINX RU (Figura 27 B). As quantificações para expressão de RNAm e conteúdo proteico de Caspase 3 mostram tendência e, diminuição, respectivamente, dos parâmetros analisados apenas em hepatócitos de animais PINX (Figura 27 C e D).
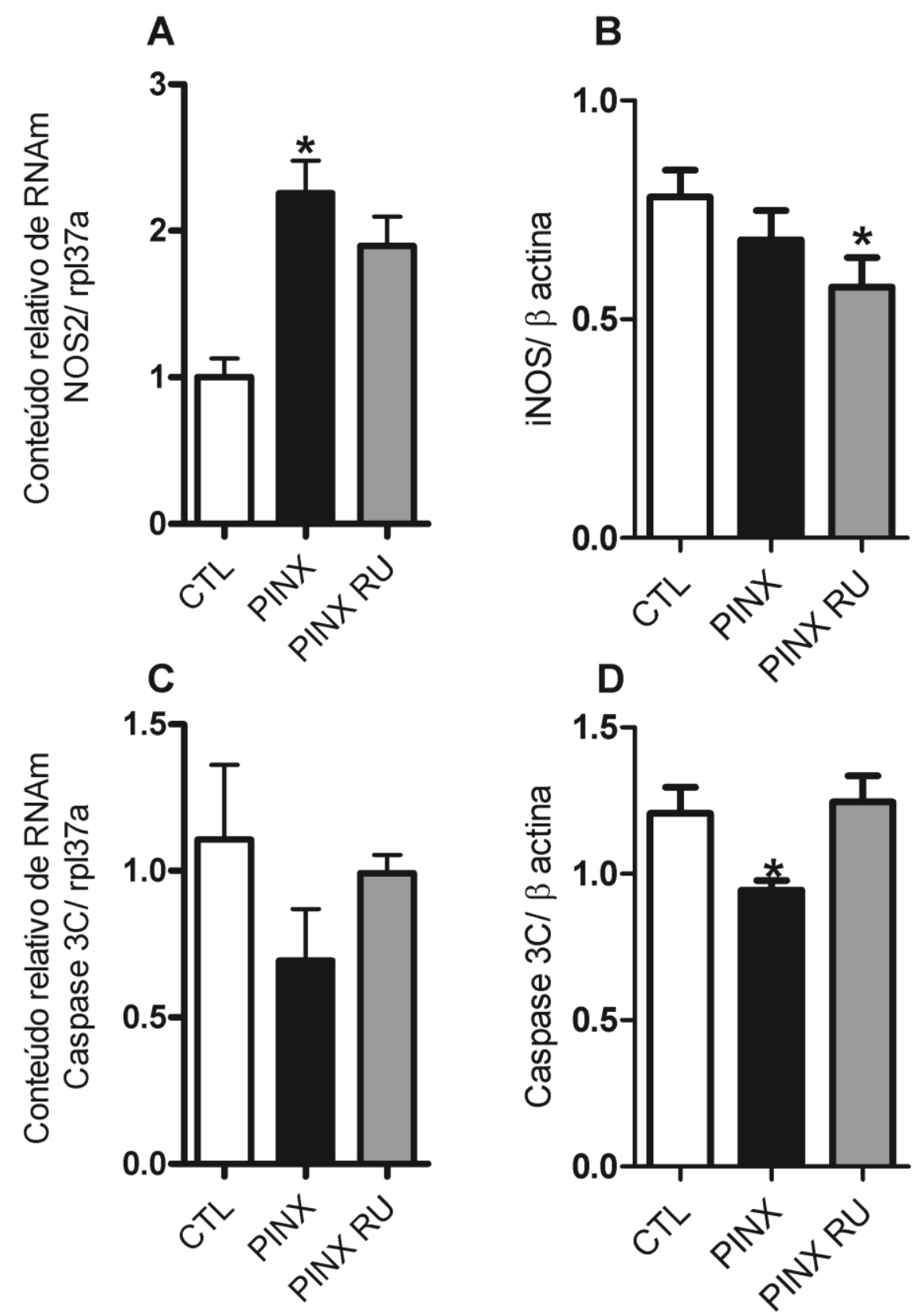

Figura 27: Expressão relativa RNAm normalizados por Rpl37a e conteúdo proteico normalizados por $\beta$ actina de NOS2 (A), Caspase 3C (C) e iNOS (B) e Caspase 3C (D), respectivamente; nas condições CTL, PINX e PINX $R U$. Os valores são resultados das médias $+/$ - os erros padrões * $p<0,05$ vs. $C T L, n=5 /$ grupo. 
A expressão relativa de SOD2 apresentou aumento em PINX (Figura 28 A) assim como P53 (Figura 28 B) e TGF $\beta 1$ (Figura 28 C). Enquanto que, o conteúdo protéico de TLR4 aumentou em PINX RU (Figura 28 D).
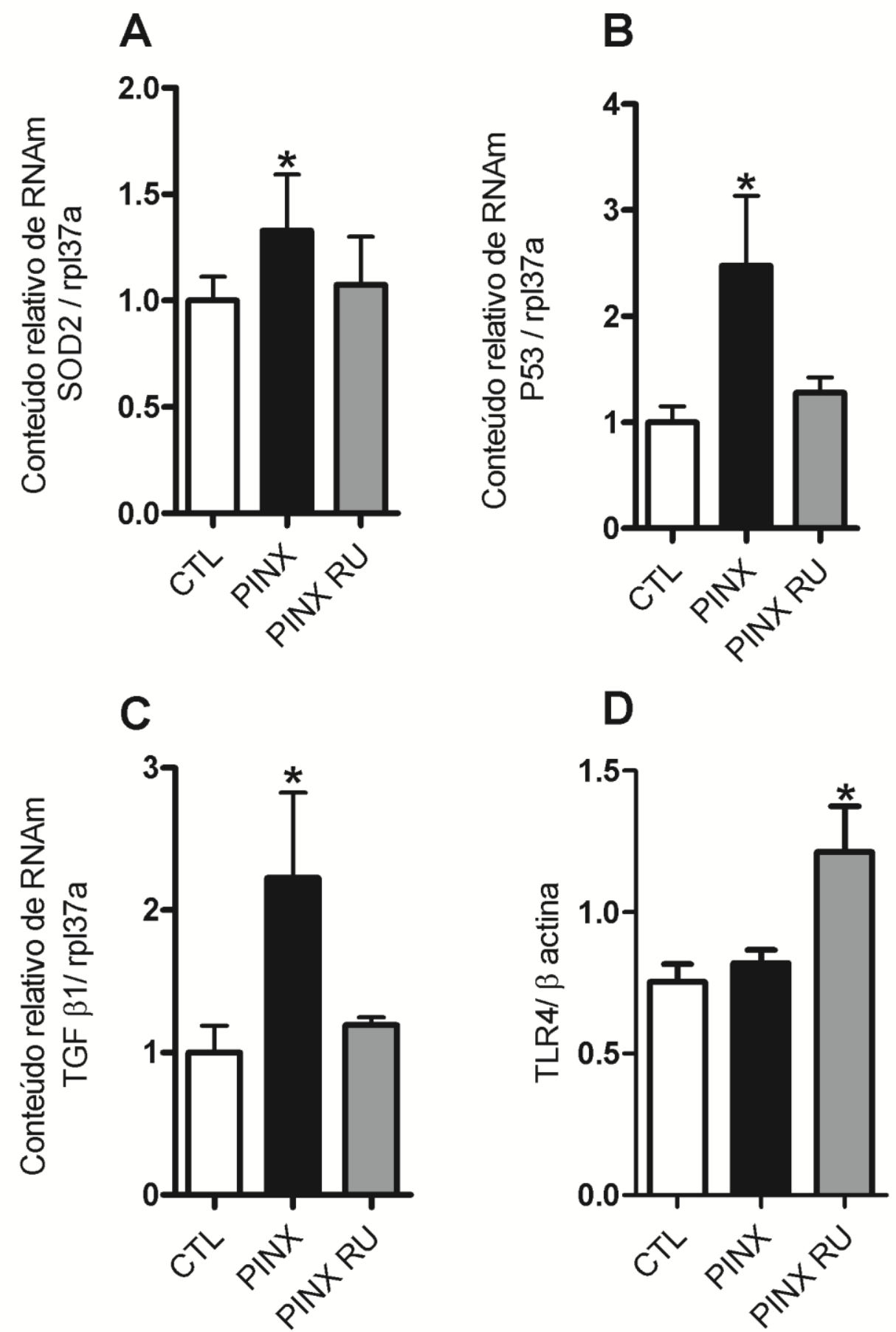

Figura 28: Quantificação hepática de mRNA de genes SOD2 (A), P53 (B) e TGF $\beta 1$ (C) normalizados por Rpl37a e conteúdo proteico de e TLR 4 (D) normalizado por $\beta$ actina, nas condições CTL, PINX e PINX RU. Os valores são resultados das médias $+/$ - os erros padrões * $p<0,05$ vs. CTL, $n=4 /$ grupo ( $A, B, C)$ e $n=7 / g r u p o$ (D). 
Quanto à STAT3, houve aumento da expressão relativa de RNAm e do conteúdo protéico em PINX RU (Figura 29 A e B), enquanto que a fosforilação da STAT3 (ou p-STAT3) não mostra alteração nos grupos estudados (Figura $29 \mathrm{C}$ ). Assim, o gráfico da fosforilação pelo conteúdo de STAT3, aponta diminuição significativa desta relação em PINX RU (Figura 29 D).
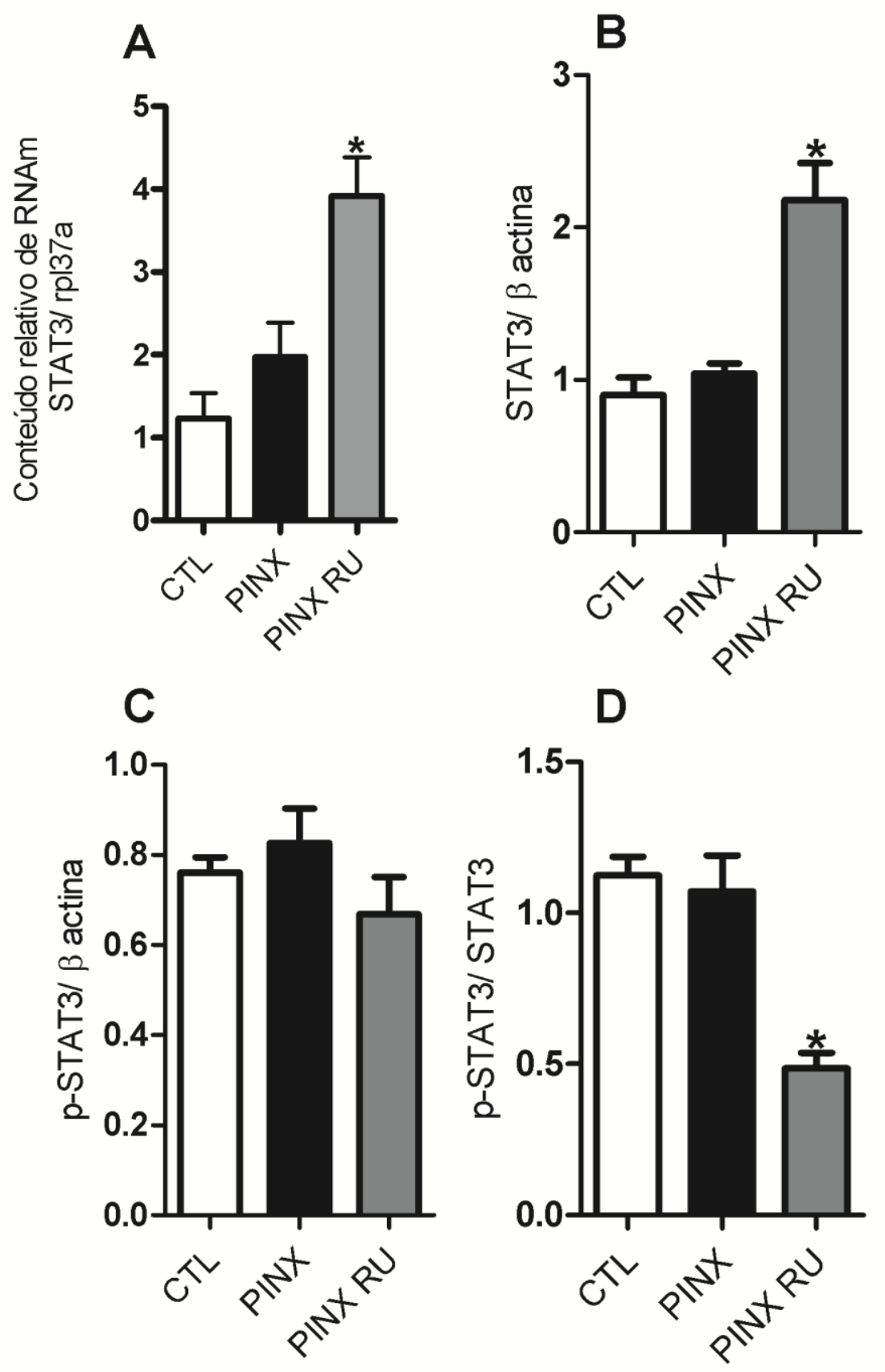

Figura 29: Expressão gênica de $\operatorname{STAT3~(A)~e~seu~conteúdo~proteico~(B);~p-STAT3~(C)~e~relação~entre~}$ fosforilação e conteúdo de STAT3 (D) normalizados por Rpl37a e $\beta$ actina, nas condições CTL, PINX e PINX RU. Os valores são resultados das médias $+/$ - os erros padrões * $p<0,05$ vs. $C T L, n=4 / g r u p o$ ( $A$ ) e $n=8 / g r u p o$ ( $B, C$, D). 


\section{DISCUSSÃO}

\subsection{EFEITOS DA RETIRADA DA GLÂNDULA PINEAL E DO BLOQUEIO FARMACOLÓGICO DA SINALIZAÇÃO DO RECEPTOR DE GLICOCORTICÓIDES SOBRE O METABOLISMO ENERGÉTICO HEPÁTICO}

Grande parte do estímulo para expressão e ação de enzimas-chave controladoras do ajuste metabólico hepático está relacionada aos níveis basais e às flutuações circadianas de hormônios que podem alterar a glicemia, como a corticosterona (cortisol em humanos), glucagon e insulina (IYNEDJUAN, 1993; MAGNUSON et al., 1989). A presença de 6-sufatoxi-melatonina drasticamente menor na urina de animais PINX demonstra os potentes efeitos da cirurgia de pinealectomia no sentido de diminuir drasticamente a quantidade de melatonina produzida sistemicamente, e, por conseguinte, metabolizada no organismo.

A flutuação ultradiana nos níveis de insulina em PINX, comparados ao CTL, mostraram padrão secretório invertido no período transitório entre as fases de claro e escuro. Neste período, há menor secreção de insulina e níveis mais elevados de corticosterona em PINX. Dessa maneira, seria esperado que maiores níveis de corticosterona levassem à hiperglicemia nos períodos de transição claro-escuro, já que a corticosterona é um hormônio hiperglicemiante e de função bem estabelecida na marcação fisiológica endócrina do período ativo da espécie (GIROTTI; WEINBERG; SPENCER, 2009). Entretanto, a glicemia dos ratos PINX não variou significativamente entre os ZTs 9 e 15, indicando que os efeitos da sinalização aumentada do GR sobre os níveis glicêmicos, resultantes da pinealectomia, se estende à tecidos extra-hepáticos no período, em especial ao pâncreas endócrino.

A menor insulinemia observada no ZT $10 \mathrm{em}$ animais pinealectomizados foi acompanhada de maior secreção da célula $\beta$, indicando, neste momento de maior ação de glicocorticóides, um esforço adicional do pâncreas na restauração de uma sinalização insulínica adequada no período de resistência periférica, que poderá levar futuramente a apoptose da célula $\beta$ pancreática (RAFACHO, 2014; RAFACHO et al., 2014). Já foi demonstrado que os efeitos deletérios na homeostase da glicose são compensados pelo aumento da secreção estática de insulina e da massa da 
célula $\beta$ pancreática, compensações associadas à up regulação da AKT (PROTZEK et al., 2014).

Sabe-se que níveis supra fisiológicos de glicocorticóides (naturais ou sintéticos) induzem a efeitos na homeostase da glicose, como diminuição da sensibilidade periférica à insulina, intolerância à glicose e dislipidemias (BUREM et al., 2002; MCMAHON; GERICH; RIZZA, 1988; RUZZIN; WAGMAN; JENSEN, 2005; SCHACKE; DOCKE; ASADULLAH, 2002), o que parece estar ocorrendo após a pinealectomia.

De fato, é bem conhecido que o uso crônico de glicocorticóides sintéticos pode promover, em longo prazo, a perda da capacidade secretora da célula $\beta$ pancreática compensatória à resistência periférica à insulina, resultando no diabetes mellitus (FRANSSON et al., 2014) e que as ilhotas pancreáticas são alvos influenciados diretamente pelos efeitos diabetogênicos dos glicocorticóides (DELAUNAY et al., 1997).

A influência da ausência de melatonina na maior secreção de insulina pelas ilhotas pancreáticas parece ocorrer de maneira aguda e concordante à capacidade da melatonina em reduzir diretamente a secreção de insulina in vitro (PICINATO et al., 2002), esta, ainda, é indiferente à sinalização do GR no pâncreas endócrino. Os mecanismos responsáveis pela resposta da célula $\beta$ ainda não são consenso e apresentam discordâncias quanto à influência mútua desses hormônios em análises in vitro versus in vivo (COSTES et al., 2015; PESCHKE; BÄHR; MÜHLBAUER, 2015;).

Entretanto, nossos resultados mostram que, pelo menos em parte, a resposta metabólica hepática à pinealectomia representa os efeitos do excesso de glicocorticóides, como descrito a seguir.

A primeira evidência do efeito preponderante dos glicocorticóides, a despeito da presença ou não de melatonina, é a capacidade do antagonista do receptor de glicocorticóide reverter a produção de glicose a partir de piruvato induzida pela pinealectomia. O fígado dos ratos PINX parece apresentar resistência à insulina, já que a fosforilação da AKT estimulada pela insulina exógena foi significativamente menor nestes animais. De acordo com a nossa hipótese, o bloqueio farmacológico das ações hepáticas dos glicocorticóides restaurou a fosforilação máxima da AKT induzida pela insulina. $\mathrm{O}$ tratamento com RU 486 aumentou a fosforilação da AKT 
basal e estimulada com insulina, efeito este já descrito anteriormente (NIKOLIC et al., 2013).

A segunda evidência se baseia no aumento do conteúdo protéico de $11 \beta$ HSD1 no fígado de ratos PINX e sua reversão pelo tratamento com RU 486. Sabe-se que a atividade intracelular dos glicocorticóides é principalmente dependente da atividade das isoezimas $11 \beta$ hidroxi-esteróide desidrogenases (11ß HSD), e não exclusivamente da concentração de glicocorticóides circulantes. O tipo 1 da $11 \beta \mathrm{HSD}$ é uma redutase que catalisa a conversão dos inativos 11-ceto-glicocorticóide cortisona e 11-de-hidro-corticosterona nos ativos $11 \beta$ hidroxi-cortisol e corticosterona, que é altamente expressa em fígado, tecido adiposo e cérebro (JAMIESON; CHAPMAN; SEXKL,1999; TOMLINSON et al., 2004). 11ß HSD1 vem sendo apontada como de provável ação em mecanismos de diversas doenças humanas, incluindo a resistência à insulina e síndrome metabólica (SENESI et al., 2010). Assim, como etapa limitante da atividade intracelular dos glicocorticóides, o aumento de seu conteúdo intracelular deve refletir na ação aumentada dos glicocorticóides no fígado dos ratos PINX, a despeito da ausência de variação do conteúdo de GR entre animais controle e PINX.

A hexose-6-fosfato desidrogenase ( $\mathrm{H} 6 \mathrm{pd})$ é uma enzima luminal do retículo endoplasmático que oxida glicose-6-fosfato, glicose e outros substratos utilizando NAD ou NADP como coenzimas (SENESI et al., 2010). Devido a características particulares de aporte de nucleotídeos no retículo endoplasmático, H6pd fornece NADPH para redutases luminais. A principal destas enzimas é a $11 \beta$ HSD1, dessa forma; seria esperado que os conteúdos protéicos (funcionais) de H6pd e $11 \beta$ hds 1 sejam concordantes ao longo dos grupos analisados. O aumento de ambos os parâmetros em PINX, mostra maior oxidação de glicose e maior atividade de retículo em animais submetidos à retirada da pineal. Os conteúdos de RNAm para ambas as proteínas, no entanto, não variaram conforme seus conteúdos protéicos, indicando que deve haver possivelmente alterações pós-transcricionais ou em mecanismos de degradação de tais proteínas no tecido hepático.

A terceira evidência, embora mais complexa até o momento, indica que a regulação da expressão gênica no fígado pela maior secreção de glicocorticóides depende também da ação combinada da insulina neste tecido. A seguir, serão discutidos os resultados obtidos de expressão das principais enzimas hepáticas 
atuantes no metabolismo energético e os possíveis mecanismos envolvidos em sua regulação.

PEPCK é codificada pelo gene PCK-1 e é responsável pela primeira etapa da gliconeogênese, gerando fosfoenolpiruvato a partir de oxaloacetato (YUEBIN et al., 2011); enquanto que a G6Pase, codificada pelo gene G6pc é responsável pela última etapa do processo, catalisando a hidrólise da glicose-6-fosfato (G6p) em glicose e fosfato $(\mathrm{Pi})$ e exercendo papel fundamental na regulação da homeostasia glicêmica (FOSTER; NORDLIE, 2002). As evidências acumuladas nos últimos 60 anos demonstram que, além do controle direto da produção hepática de glicose por metabólitos da glicose, este fenômeno é modulado por hormônios conhecidos como contra-reguladores da ação da insulina e pela própria insulina (MOORE; CONNOLLY; CHERRINGTON, 1998).

A insulina exerce uma potente ação hepática que resulta na supressão da produção hepática de glicose. O mecanismo proposto para esta ação envolve a inibição do fator de transcrição forkhead box-other 1 (FoxO1), que tem a capacidade de aumentar a expressão das enzimas PEPCK e G6Pase (ZHANG et al., 2006). O mecanismo pelo qual a insulina inibe a atividade transcricional do FoxO1 envolve sua fosforilação em resíduos de serina e treonina pela AKT (BRUNET et al., 1999).

De maneira contrária às ações da insulina, a expressão da PEPCK e da G6Pase é estimulada pelo glucagon, pelas catecolaminas e pelos glicocorticóides. Os mecanismos pelos quais estes hormônios controlam a expressão destas enzimas ainda não são consenso, mas certamente envolvem a ativação conjunta de diversos fatores de transcrição tais como peroxisome proliferator-activated receptor gamma coactivator 1-alpha (PGC1a), GR, hepatocyte nuiclear fator-3 (HNF3) e HNF-NF-kB4 (BARTHEL; SCHMOLL, 2003). Em última análise, a eficiência destes hormônios em promover a produção hepática de glicose os define como contra-reguladores da ação da insulina.

Desta maneira, o controle da PHG, não parece ser preponderantemente dependente da expressão gênica das enzimas, mantida em níveis normais pela maior sinalização da corticosterona no ZT 10 em ratos sem melatonina central. No entanto, é possível que a PHG seja majoritariamente regulada pela atividade de PEPCK e G6pase, efeitos parácrinos provenientes da maior expressão de Gys, 
oferta hepática de substratos energéticos, alterações no comportamento alimenta oriundas da pinealectomia (PATTON et al., 2013), entre outros.

Ainda, é possível que a diminuição na expressão de G6pc em PINX RU, esteja associada ao aumento do estímulo para expressão de GLUT2 e ACC a, que, poderiam dirigir o aporte aumentado de glicose para a lipogênese no fígado nos animais PINX tratados com RU 486.

GLUT2 é o transportador de glicose que é expresso no fígado, pâncreas, intestino, rim e cérebro (LETURQUE; BROT-LAROCHE; LE GALL, 2009). Este transportador é fundamental para a secreção de insulina e captação hepática de glicose, posto que, devido ao seu alto Km (constante de Michaelis-Menten), permite a captação de glicose quando sua concentração circulante é elevada.

Embora, após a pinealectomia, o conteúdo protéico de GLUT2 hepático não tenha sido distinto entre os grupos estudados, o claro estímulo para aumento da expressão nos fígados de GLUT2 em PINX RU, indica ser a corticosterona elevada no ZT 10, através de sua sinalização via GR, a responsável pelo controle da expressão gênica e protéica de GLUT2 encontrados em animais pinealectomizados no ZT 10.

A tendência a menor conteúdo de GLUT2 no fígado de PINX parece estar diretamente relacionada aos maiores níveis de corticosterona em animais pinealectomizados no período de transição claro-escuro. Já foi visto que a dexametasona é capaz de inibir a captação de glicose em músculo esquelético e em mioblastos em cultura de frangos por inibir a expressão protéica de Glut1 (ZHAO et al., 2012). Devido às semelhanças existentes nos tecidos muscular esquelético e hepático quanto ao metabolismo energético, à tolerância sistêmica à glicose e à responsividade aos hormônios metabólicos, poderíamos esperar que a corticosterona elevada no período estudado, seja responsável, via sinalização por GR, pela tendência à diminuição do conteúdo protéico de GLUT2 hepático, de modo a contribuir para um de seus efeitos clássicos, a manutenção da glicemia elevada (GIROTTI; WEINBERG; SPENCER, 2009). .

Por sua vez, a ACC a é a subunidade catalítica da ACC que, quando ativada por desfosforilação, catalisa a carboxilação da acetil-CoA, reação central da síntese de novo de ácidos graxos (HARDIE; CARLING, 1997). Embora não tenham sidos avaliados o conteúdo e a atividade desta proteína, é possível que uma maior 
captação e metabolização de glicose seja direcionada para a lipogênese nos ratos PINX RU e para o maior estoque na forma de glicogênio, como observado por diferentes análises.

A Gys é uma enzima que, juntamente com a enzima de ramificação do glicogênio, incorporam glicose ao glicogênio durante a hiperglicemia, catalisando a formação de ligações glicosídicas em diferentes pontos da molécula de glicogênio. Nos mamíferos, a isoenzima muscular 1 (Gys1) é expressa ubiquamente, mas no fígado, a isoenzima hepática 2 (Gys2) é de expressão predominante $(\mathrm{ROACH}$, 2002).

Interessantemente, a expressão relativa de Gys2 é maior em PINX RU, resultado que aparentemente não se relaciona aos conteúdos de glicogênio hepático observados por diferentes técnicas. A taxa de incorporação de glicose em glicogênio hepático se correlaciona diretamente com a atividade Gys, que é inativada alostericamente por mecanismos de fosforilação e ativada por desfosforilação (FERRER et al., 2003; GOMIS; FERRER; GUINOVART, 2000; LAWRENCE; $\mathrm{ROACH}, 1997)$. Além disto, é possível que, semelhante ao observado em diversos outros genes (por exemplo, 11 $\beta$ hds1, H6pd, GLUT2 e NOS2), o conteúdo proteico não corresponda às alterações observadas na expressão do mRNA. Assim, nossa análise necessita de investigação mais detalhada.

No entanto, no músculo esquelético a inativação de Gys pode decorrer por estímulo alostérico da G6p (glicose-6-fosfato), cuja concentração intracelular aumenta quando o transporte de glicose é aumentado via Glut4 (BOUSKILA et al., 2010; HUNTER et al., 2011). O aumento da deposição de carboidratos (glicogênio hepático) no fígado de PINX pode ser atribuído ao maior aporte de glicose no fígado ao longo do dia. Descrevemos anteriormente animais PINX apresentam hiperglicemia noturna (NOGUEIRA et al., 2011), resultados estes, confirmados neste trabalho. $O$ aumento de intensidade de coloração para carboidratos neutros indica o maior deposição de glicogênio hepático em PINX e a reversão dessa alteração pelo bloqueio da sinalização de glicocorticóides, já apontadas por nosso ensaio de digestão de tecido hepático.

Nossos dados mostram que em PINX há aumento hepático da expressão de ACC $\alpha$, enzimas málicas (Me1, 2 e 3), FAS $\mathrm{N}$ e Dgat2, que pode estar relacionado não apenas à menor insulinemia de PINX no ZT 10, como também diretamente 
influenciado pelos níveis elevados de corticosterona, fruto da pinealectomia. Esses dados sugerem influência direta da pinealectomia sobre níveis transcricionais de ACC a e Me3 e influência indireta da pinealectomia, que através da ação direta dos glicocorticóides, age aumentando a expressão hepática de Me1, Me2, FAS N e Dgat2 na pinealectomia, indicando maior estímulo lipogênico após perda da melatonina noturna de secreção central.

As enzimas málicas catalisam a formação de piruvato a partir de malato (BARROSO; SANTISTEBAN, 1999) e a ACC catalisa a carboxilação da acetil-CoA, reação mais importante da síntese de novo de ácidos graxos (MAO et al., 2006), enquanto que a FAS $\mathrm{N}$ catalisa a conversão de malonil CoA em palmitato (UYEDA; YAMASHITA; KAWAGUCHI, 2002). A maior expressão de ACC a e Me3 no fígado de PINX e PINX RU sugere maior estimulo para a síntese de triglicerídeos no fígado (AL-DWAIRI et al., 2012) e hipotetizamos que, neste caso, a maior sinalização via GR no ZT 10 vista em animais pinealectomizados, contribua para a restauração dos níveis diminuídos de triglicerídeos circulantes desses animais, que, ao mesmo tempo, apresentam maior taxa de gliconeogênese.

Concordante com essa idéia, vimos que os níveis de Mttp, Sec22b, Cd 36 e LXR seguem mesmo padrão de aumento de expressão relativa em ratos pinealectomizados e total reversão após tratamento com RU 486. Esses dados sugerem que a sinalização aumentada via GR no ZT 10 seja responsável também por aumento na ativação de genes relacionados ao metabolismo do colesterol e ao metabolismo geral de ácidos graxos, principalmente relacionados à captação de lipídeos.

Mttp codifica uma proteína relacionada ao transporte microssomal de triglicerídeos (HUSSAIN; SHI; DREIZEN, 2003; RAABE et al., 1999; WETTERAU; LIN; JAMIL, 1997) enquanto que o tráfico intracelular de colesterol é mediado por Sec22b, que codifica um dos componentes do complexo SNARE, essencial no transporte de VLDL ao Complexo de Golgi (SIDDIQI; MANI; SIDDIQI, 2010). CD36 é a mais importante proteína envolvida na captação de ácidos graxos em diferentes tecidos (BONEN et al., 2007 ) e LXR regula genes relacionados ao metabolismo e efluxo de colesterol e à captação geral de lipídeos no fígado.

Além disso, LXR têm sua expressão influenciada por variações no processamento de lipídios (SZANTO; ROSZER, 2008), que deve ser principalmente 
afetado em PINX, dada a inalteração nos níveis circulantes de colesterol total e os efeitos já mencionados dos glicocorticóides sobre o metabolismo lipídico.

Os resultados apresentados até o momento são claros quanto às alterações no metabolismo energético, notadamente glicêmico, dos animais PINX. Além disso, já são bem conhecidas as alterações em parâmetros corpóreos desses animais, refletindo as mudanças metabólicas e comportamentais (TERRÓN et al., 2013), também observadas neste estudo.

Nossos resultados de avaliação da porcentagem relativa de adiposidade periabdominal refletem os efeitos típicos da insulina sobre seus tecidos-alvo clássicos. Isto deve incluir, em PINX, menor lipogênese no tecido adiposo em decorrência do baixo estímulo insulinêmico. Da mesma forma, a diminuição de massa muscular em PINX e PINX RU pode ser consequência do alto estímulo proteolítico da corticosterona nessas condições (VEGIOPOULOS; HERZIG, 2007). Estas alterações devem contribuir para o menor peso corpóreo, que também se reflete no menor peso do fígado, observado em PINX.

O bloqueio da sinalização adequada da corticosterona reverteu a maioria das alterações vistas em animais PINX, com exceção da massa muscular, que pode ser decorrente do curto período de tratamento com RU 486. Porém, não descartamos a contribuição da ausência de melatonina da glândula pineal para permanência de menor massa muscular em PINX RU, já que é possível que a melatonina interfira na expressão de IGF-1 independentemente dos níveis de GH quando há alteração do fotoperíodo (DAHL; TAO; THOMPSON; 2012).

Visando à compreensão das alterações que o modelo de estudo causa no âmbito celular, encontramos influência da pinealectomia sobre a diminuição do citoplasma dos hepatócitos, e conseqüentemente, da área celular. Os efeitos dos níveis elevados de corticosterona no ZT 10 levam à depleção de substratos energéticos hepáticos de localização citoplasmática nos hepatócitos e assim diminuem a área da célula. A contagem histológica dos núcleos indica proliferação celular provavelmente compensatória à tendência de instalação de um quadro próinflamatório no tecido hepático de PINX, devido às expressões de RNAm obtidas para marcadores inflamatórios e níveis de corticosterona elevados no ZT 10. 
Sabe-se que TNF pode isoladamente influenciar a proliferação celular em tecidos saudáveis e tumorais, estimulando a proliferação celular em algumas linhagens e inibindo-a em outras (SUGARMAN et al., 1985).

No fígado, TNF está envolvido na fisiopatologia da hepatite viral, doença hepática alcóolica, DHGNA e injúria por isquemia/reperfusão, dentre outros. Além disso, TNF atua sobre a morte celular, a proliferação de hepatócitos e regeneração hepática (SCHWABE; BRENNER, 2006).

Adicionalmente, a corticosterona aumentada no ZT 10 também pode promover alteração do volume celular no fígado de PINX por afetar a expressão dos genes IGF-1 e IGF-2. Em fetos de ovelha, os glicocorticóides elevam a expressão de IGF-1 no fígado e a inibem no músculo esquelético, além de inibirem a expressão de IGF-2 em ambos (LI et al., 1993; Ll et al., 1996; LI et al., 2002).

Recentemente, foi esclarecido o mecanismo pelo qual níveis elevados de TNF são capazes de aumentar a liberação de glicocorticóides e a modulação precoce da resposta imune sistêmica. Recentemente, Glennon et al., (2015) mostraram que a instalação de um quadro pró-inflamatório com níveis elevados de TNF estimula a ativação do eixo hitotálamo-hipófise-adrenal, que através de uma população residente de células dendríticas na glândula pineal, permite que citocinas próinflamatórias sejam capazes de elevar a liberação de glicocorticóides (GLENNON et al., 2015).

\subsection{EFEITOS DA RETIRADA DA GLÂNDULA PINEAL E DO BLOQUEIO FARMACOLÓGICO DA SINALIZAÇÃO DO RECEPTOR DE GLICOCORTICÓIDES SOBRE INFLAMAÇÃO HEPÁTICA}

O sistema neuroendócrino modula o sistema imune através de neuropeptídios e hormônios (ADER, 2007), o que indica a existência de um sistema neuroimunoendócrino (BLALOCK; SMITH, 1985), no qual a melatonina desempenha importante papel.

Dependendo do contexto, a inflamação pode ser tanto benéfica quanto prejudicial à função hepática. Uma resposta inflamatória branda, isto é, limitada em sua intensidade e duração, parece exercer efeitos hepato-protetores, contribuindo para o reparo tecidual e promovendo o restabelecimento da homeostasia. Por outro 
lado, a inflamação excessiva, crônica e desproporcional na sua intensidade, pode induzir a perda maciça dos hepatócitos e exacerbar a severidade de diversas condições patológicas, incluindo alterações metabólicas sistêmicas como a obesidade, diabetes e DHGNA (NIKOLAOU; SARRIS; TALIANIDIS, 2013).

A ativação do fator de transcrição NF-KB e da enzima c-jun-NH2-kinase (JNK) pelos estímulos extracelulares envolvidos na inflamação são determinantes centrais do destino celular. Embora a ativação do NF-kB apresente efeitos anti-apoptóticos, a ativação da sinalização por JNK parece induzir tanto a proliferação quanto a apoptose (DHANASEKARAN; REDDY, 2008; DU et al., 2004; GURURAJAN et al., 2005).

A via do NF-KB é ativada por vários estímulos, incluindo o LPS e citocinas como TNF e IL1, que desencadeiam suas ações após a ligação aos receptores do tipo Toll e aos receptores de TNF ou IL1, respectivamente TNF R1 ou IL1R (OECKINGHAUS; HAYDEN; GHOSH, 2011; WEST; KOBLANSKY; GHOSH, 2006).

A família do NF-kB consiste de 5 fatores de transcrição (p50, p52, p65, cRel e RelB) que compartilham um $\mathrm{N}$-terminal homólogo, que corresponde ao domínio de dimerização e de ligação ao DNA. Homodímeros e heterodímeros de NF-kB têm localização citoplasmática quando estão ligados, de forma não-covalente, às proteínas IkB. Frente à estimulação celular, IkB é fosforilado pelo complexo inibidor da IkB quinase (IKK), composto por uma subunidade regulatória (IKK $\alpha$, IKK $\beta$ ou IKK $\varepsilon$ ) e uma subunidade catalítica (IKK $\gamma /$ NEMO). A fosforilação do IkB resulta em sua ubiquitinação e degradação pelo complexo de proteassoma $26 \mathrm{~S}$. Os dímeros de NF-KB livres podem então ser translocados para o núcleo e ativar a transcrição de genes codificadores de citocinas, quimiocinas e fatores anti-apoptóticos que promovem a sobrevivência e o crescimento celulares (BEN-NERIAH; KARIN, 2011).

As citocinas TNF e IL1 $\alpha$, o receptor IL1 R1 e IKK $\beta$ apresentaram tendência a aumento de expressão nos animais PINX e aumento em PINX RU. Em termos de transcrição gênica, NF-kB parece não ter sofrido influência para aumentar sua expressão gênica apenas em resposta à proteínas que poderiam estimulá-lo upstream. A corticosterona parece afetar diretamente, via sinalização por GR, os níveis de transcrição de NF-KB no ZT 10, assim como de IL1 RN, enzimas lipídicas como as málicas 1 e 2, FAS N, Dgat2, Mttp, Sec22b, CD36 e LXR além de proteínas 
relacionadas ao estresse oxidativo como SOD2 e P53 (FRANCK et al., 2014), que apresentam alterações de mesmo perfil de expressão gênica nos grupos estudados.

Parte dos efeitos antiinflamatórios da melatonina ocorre por conta da inibição do gene da NF-kB em decorrência da menor oferta de NO a partir de iNOS, sabe-se que a melatonina inibe a produção de iNOS e, assim, de NO proveniente de iNOS em macrófagos estimulados (GILAD et al., 1998).

Além disso, já foi descrito que, no músculo liso, dexametasona aumenta a expressão de NOS2, mas reprime a tradução do gene, sem alterações na ativação do NF-kB (THAKUR, BAYDOUN; 2012). A natureza dos nossos achados parece ser complexa, podendo, inclusive, influenciar a ativação de células de Kupffer no fígado.

Especificamente quanto ao estresse oxidativo hepático, a análise de expressão de P53 e SOD2 mostrou variações de padrão similar às alterações na transcrição gênica de NOS2, ou seja, PINX tem desequilíbrio oxidativo no ZT 10 revertido pelo tratamento com RU 486. No entanto, para melhor elucidação dos mecanismos destas alterações são necessárias futuras investigações que incluem análises hepáticas tais como imunohistoquímica, taxa de translocação de NF-kB para o núcleo, conteúdo e fosforilação dos principais agentes protéicos envolvidos.

Sabe-se que a ativação da via de sinalização intracelular JNK-IKK $\beta$ pode resultar em resistência à insulina, pois promove a fosforilação em resíduos de serina do substrato do receptor de insulina (IRS), o que inibe a fosforilação em tirosina e a interação do IRS com a PI3K, impedindo assim a resposta tecidual à insulina (HOSTAMISLIGIL, 2003; HOSTAMISLIGIL, 2006). Além disto, Jnk pode fosforilar vários substratos e o resultado da ativação destes fatores determinam a sobrevida ou morte celular (BOGOYEVITCH; KOBE, 2006). O padrão de ativação de JNK e de expressão de seus genes alvos ainda não foi analisado, entretanto, a redução de caspase 3, que regula principalmente a fragmentação do DNA na apoptose (ABBAS; LICHTMAN; PILLAI, 2008) e o aumento da contagem de núcleos na histologia do tecido hepático indicam provável efeito anti-apoptótico e de proliferação celular com envolvimento de resistência à insulina nos ratos PINX.

NF-kB é um mediador intracelular promíscuo de vários estímulos fisiológicos e apresenta expressão relativa de RNAm elevada em PINX, que, dependo de sua taxa de translocação, pode indicar que as alterações metabólicas e inflamatórias observadas neste projeto (IL1 RN, na função da célula $\beta$ pancreáticas e da H6pd, 
síntese de ácidos graxos) estão relacionas, em primeira instância, à sinalização por GR aumentada no ZT 10 em PINX.

Para entender os mecanismos envolvidos no estabelecimento do quadro próinflamatório no fígado dos animais pinealectomizados, foram investigadas outras possíveis proteínas com potencial envolvimento neste fenômeno.

Um dos mais potentes ativadores do NF-KB são moléculas derivadas de patógenos (como LPS), que estimulam TLR4- receptores do tipo toll 4 (KARIN; BEMNERIAH, 2000; WEST; KOBLANSKY; GHOSH, 2006). Ademais, TLR4 tem função chave na modulação do cross-talk entre os processos inflamatórios e metabólicos (TSUKUMO et al., 2007).

Observamos maior conteúdo proteico de TLR4 no fígado dos animais PINX RU no ZT 10, achado esse que se correlaciona aos maiores níveis de colesterol LDL circulantes, sugerindo que a sinalização por TLR4 pode estar relacionada também às alterações metabólicas em PINX RU.

Recentemente evidências da relação entre TLR4 e LDL vêm sendo descritas. Ding et al., (2015) mostraram evidências da existência de uma ligação entre lectinlike ox-LDL receptor 1 (LOX-1) e TLR4 em células neurais de camundongo, com papel na autofagia. LOX-1 é o receptor principal da lipoproteína de baixa densidade oxidada na superfície da célula e tem regulação positiva por citocinas próinflamatórias (DING et al., 2015). Por sua vez, Choi et al., (2015) apontaram a protéina spleen tirosina quinase- SYK como reguladora da expressão do perfil MHCII em macrófagos via ativação da autofagia, envolvendo sinalização por TLR4, em resposta ao LDL oxidado.

Ademais, PINX RU apresentou aumento da expressão do STAT3 sem alteração da fosforilação absoluta, que resultou em menor fosforilação do STAT3 relativa ao seu conteúdo. Nossos resultados atuais ainda não nos permitem concluir se estas alterações resultam em mudança na atividade transcricional do STAT3. Este fator de transcrição, que pode ser ativado por IL6, participa tanto da proliferação celular na hepatocarcinogênese (BROMBERG; WANG, 2009; NAUGLER; KARIN, 2008) como da regulação do metabolismo hepático. STAT3 se liga e reprime a transcrição dos genes PCK-1 (codificador de PEPCK) e G6pc (codificador de G6pase). (RAMADOSS et al., 2009). 
Produzido principalmente por macrófagos estimulados e células $T$, uma das ações biológicas de destaque de TGF $\beta$ é a capacidade de se contrapor aos efeitos de citocinas pró-inflamatórias, inibindo assim respostas imunes e inflamatórias. Além disso, o TGF $\beta$ controla a iniciação e resolução de respostas inflamatórias através da regulação da quimiotaxia, ativação, e sobrevivência dos linfócitos, macrófagos, mastócitos e granulócitos e células natural killers. A atividade reguladora de TGF $\beta$ é modulada pelo estado de diferenciação celular e pela presença de citocinas inflamatórias e moléculas co-estimuladoras (LI et al., 2006).

Nossos resultados indicam efeito compensatório de estímulo da expressão de TGF $\beta$ em ratos pinealectomizados em resposta não só ao desequilíbrio oxidativo, mas também às maiores expressões de IL1 $\alpha$ e principalmente de IL1 RN no fígado de PINX. De acordo, já foi descrito que na ausência de IL1 RN, a cicatrização de feridas em camundongos é prejudicada por uma ativação inadequada do NF-KB e a supressão da via de sinalização do TGF $\beta$ (ISHIDA et al., 2006). Tal efeito compensatório parece ser dependente da maior taxa de transdução de sinal da corticosterona via GR durante o período de transição claro-escuro; posto que o bloqueio de GR mantém a expressão de TGF $\beta$ normalizada, apesar do aumento da expressão de IL1a no grupo.

Dessa forma, na maior presença de TGF $\beta$ no fígado de ratos PINX é esperada menor expressão de Caspase 3 clivada (ativa), conforme visto em nossos resultados. Considerando-se a maior presença de TGF $\beta$ (pró-proliferação) como limitante do conteúdo de Caspase 3 clivada (pró-apoptótica) seria esperado que essa mantivesse sua variação inversa à da TGF $\beta$ e, da mesma maneira que TGF $\beta 1$, tenha sua expressão alterada em PINX devido à transdução de sinal via GR exacerbada no ZT 10.

Assim, nossos resultados apontam correlação entre a sinalização hepática por GR e a expressão de genes relacionados à inflamação e estresse oxidativo durante o ZT 10, além de achados histológicos que, possivelmente, se relacionam às alterações no metabolismo energético hepático observadas nesta pesquisa. 


\section{CONCLUSÕES}

Tomados em seu conjunto, os resultados desta tese apontam que as alterações observadas no ZT 10 em animais pinealectomizados, quanto ao metabolismo energético e a modulação da inflamação hepática, relacionam-se entre si e decorrem do aumento da corticosterona no período de transição claro-escuro. A melatonina parece influenciar a secreção de glicocorticóides no período, que age direta e conjuntamente à melatonina, nas alterações dos aspectos avaliados no ZT10.

\subsection{METABOLISMO HEPÁTICO ENERGÉTICO}

O aumento dos níveis circulantes de corticosterona no ZT 10 decorre da ausência de melatonina proveniente da glândula pineal.

A sinalização hormonal via receptor de glicocorticóides regula a maior parte das ações da melatonina sobre o metabolismo da glicose e a resposta hepática à insulina. Além disso, alterações relacionadas à gliconeogênese e ao estoque de glicogênio também decorrem de ação direta de glicocorticóides sobre o fígado.

As alterações observadas quanto ao metabolismo energético hepático se relacionam ao desequilíbrio no status transcricional de várias proteínas possivelmente indicadoras da inflamação e estresse oxidativo no tecido hepático.

\subsection{INFLAMAÇÃO HEPÁTICA}

Parece haver participação conjunta dos glicocorticóides e da ausência de melatonina central sobre a modulação da inflamação hepática.

Os eventos que regulam a proliferação celular e a apoptose do tecido hepático podem ser conseqüência principalmente das ações dos glicocorticóides. 


\section{REFERÊNCIAS*}

ABBAS, A. K.; LICHTMAN, A. H.; PILLAI, S. Imunologia celular e molecular. Rio de Janeiro: Elsevier, 2008.

ADER, R. (Ed.). Psychoneuroimmunology. San Diego CA:Elsevier Academic, 2007.

AL-DWAIRI, A.; PABONA J. M.; SIMMEN, R. C.; SIMMEN F. A. Cytosolic malic enzyme 1 (ME1) mediates high fat diet-induced adiposity, endocrine profile, and gastrointestinal tract proliferation-associated biomarkers in male mice. PLoS One, v. 7, n. 10, p. e46716, 2012.

ALLISON, A. C.; LEE, S. W. The mode of action of anti-rheumatic drugs. Antiinflammatory and immunosuppressive effects of glucocorticoids. Prog. Drug. Res., v. 33, p. 63-81, 1989.

ALONSO-VALE, M. I.; BORGES-SILVA, C. N.; ANHE, G. F.; ANDREOTTI, S.; MACHADO, M. A.; CIPOLLA-NETO, J.; LIMA, F. B. Light/dark cycle-dependent metabolic changes in adipose tissue of pinealectomized rats. Horm. Metab. Res., v. 36, n. 7, p. 474-479, 2004.

ARIAS, I. M.; JAKOBY, W. B.; POPPER, H. D.; SCHACHTER, D.; SHAFRITZ, D.S. The liver: biology and pathobiology. New York: Raven Press, 1988. 1336 p.

ASRIH, M.; JORNAYVAZ, F. R. Inflammation as a potential link between nonalcoholic fatty liver disease and insulin resistance. J. Endocrinol., v. 218, n. 3, p. 25-36, 2013.

BAJAJ, M.; DEFRONZO, R. A. Metabolic and molecular basis of insulin resistance. J. Nucl. Cardiol., v. 10, p. 311-323, 2003.

BARROSO, I.; SANTISTEBAN, P. Insulin-induced early growth response gene (Egr-1) mediates a short term repression of rat malic enzyme gene transcription. $\mathbf{J}$. Biol. Chem., v. 274, n. 25, p. 17997-8004, 1999.

BARTHEL, A.; SCHMOLL, D. Novel concepts in insulin regulation of hepatic gluconeogenesis. Am. J. Physiol. Endocrinol. Metab., v. 285, n. 4, p. 685-692, 2003.

BARTOL, I.; SKORUPA, A. L.; SCIALFA, J. H.; CIPOLLA-NETO, J. Pineal metabolic reaction to retinal photostimulation in ganglionectomized rats. Brain Research, v. 744, p. 77-82, 1997. 
BEHMER, O. A.; DE TOLOSA, E. M. C.; FREITAS NETO, A. G. Manual de técnicas para histologia normal e patológica. São Paulo: EDART, 1975.

BENI, S. M.; KOHEN, R.; REITER, R. J.; TAN, D. X.; SHOHAMI, E. Melatonininduced neuroprotection after closed head injury is associated with increased brain antioxidants and attenuated late-phase activation of NF-kappaB and AP-1. FASEB J., v.18, n. 1, p. 149-151, 2004.

BEN-NIRIAH, Y.; KARIN, M. Inflammation meets cancer, with NF-KB as the matchmaker. Nat. Immunol., v. 12, p. 715-723, 2011.

BLALOCK J. E.; SMITH E. M. A complete regulatory loop between the immune and neuroendocrine systems. Fed. Proc., v. 44, p. 108-111, 1985.

BOGOYEVITCH, M. A.; KOBE, B. Uses for JNK: the many and varied sub- strates of the c-Jun N-terminal kinases. Microbiol. Mol. Biol. Ver., v. 70, p. 1061-1095, 2006.

BONEN, A.; CHABOWSKI, A.; LUIKEN, J. J.; GLATZ, J. F. Is membrane transport of FFA mediated by lipid, protein, or both? Mechanisms and regulation of proteinmediated cellular fatty acid uptake: molecular, biochemical, and physiological evidence. Physiology, v. 22, p. 15-29, 2007.

BOUSKILA, M.; HUNTER, R. W.; IBRAHIM, A. F.; DELATTRE, L.; PEGGIE, M.; VAN DIEPEN, J. A.; VOSHOL, P. J.; JENSEN, J.; SAKAMOTO, K. Allosteric regulation of glycogen synthase controls glycogen synthesis in muscle. Cell Metab., v. 12, p. 456-466, 2010.

BOYCE, P.; BARRIBALL, E. Circadian rhythms and depression. Aust. Fam. Physician, v. 39, n. 5, p. 307-310, 2010.

BRADBURY M. J.; AKANA S. F.; CASCIO C. S.; LEVIN N.; JACOBSON L.; DALLMAN M. F. Regulation of basal ACTH secretion by corticosterone is mediated by both type I (MR) and type II (GR) receptors in rat brain. J. Steroid Biochem. Mol. Biol., v. 40, n. 3, p. 133-142, 1991.

BRADFORD, M. M. A rapid and sensitive method for the quantitation of microgram quantities of protein utilizing the principle of protein-dye binding. Anal. Biochem., v. 72, n. p. 248-254, 1976.

BROMBERG, J.; WANG, T. C. Inflammation and cancer: IL-6 and STAT3 complete the link. Cancer Cell, v. 15, p. 79-80, 2009.

BRUNET, A.; BONNI, A.; ZIGMOND, M. J.; LIN, M. Z.; JUO, P.; HU, L. S.; ANDERSON, M. J.; ARDEN, K. C.; BLENIS, J.; GREENBERG M. E. AKT promotes cell survival by phosphorylating and inhibiting a Forkhead transcription factor. Cell, v. 96, n. 6, p. 857-868, 1999. 
BUFIANESI, E.; MCCULLOUGH, A. J.; MARCHESINI, G. Insulin resistance: a metabolic pathway to chronic liver disease. Hepatology, v. 42, p. 987-1000, 2005.

BUREM, J.; LIU, H. X.; JENSEN, J.; ERIKSSON, J. W. Dexamethasone impairs insulin signalling and glucose transport by depletion of insulin receptor substrate-1, phosphatidylinositol 3- kinase and protein kinase B in primary cultured rat adipocytes. Eur. J. Endocrinology, v. 146, n. 3, p. 419-429, 2002.

CAHILL, G. F. Jr. Physiology of insulin in man (Banting Memorial Lecture). Diabetes, v. 20, p. 785-799, 1971.

CAILOTTO, C.; LA FLEUR, S. E.; VAN HEIJNINGEN, C.; WORTEL, J.; KALSBEEK, A.; FEENSTRA, M.; PEVET, P.; BUIJS, R. M. The suprachiasmatic nucleus controls the daily variation of plasma glucose via the autonomic output to the liver: are the clock genes involved? Eur. J. Neurosci., v. 22, n. 10, p. 2531 2540, 2005.

CAILOTTO, C.; VAN HEIJNINGEN, C.; VAN DER VLIET, J.; VAN DER PLASSE, G.; HABOLD, C.; KALSBEEK, A.; PEVET, P.; BUIJS, R. M. Daily rhythms in metabolic liver enzymes and plasma glucose require a balance in the autonomic output to the liver. Endocrinology, v. 149, n. 4, p. 1914-1925, 2008.

CALVANO, S. E.; ALBERT, J. D.; LEGASPI, A.; ORGAN, B. C.; TRACEY, K. J.; LOWRY, S. F. SHIRES, G. T. ANTONACCI, A. C. Comparison of numerical and phenotypic leukocyte changes during constant hydrocortisone infusion in normal humans with those in thermally injured patients. Surg. Gynecol. Obstet., v. 164, n. 6, p. 509-520, 1987.

CAPERUTO, L. C.; ANHÊ, G. F.; CAMBIAGHI, T. D.; AKAMINE, E. H.; DO CARMO BUONFIGLIO, D.; CIPOLLA-NETO, J.; CURI, R.; BORDIN, S. Modulation of bone morphogenetic protein-9 expression and processing by insulin, glucose, and glucocorticoids: possible candidate for hepatic insulin-sensitizing substance. Endocrinology, v. 149, n. 12, p. 6326-6335, 2008.

CARRILLO-VICO, A.; CALVO, J. R.; ABREU, P.; LARDONE, P. J.; GARCIAMAURINO, S.; REITER, R. J.; GUERRERO, J. M. Evidence of melatonin synthesis by human lymphocytes and its physiological significance: possible role as intracrine autocrine and/or paracrine substance. FASEB J., v. 18, p. 537-539, 2004.

CASTANON-CERVANTES, O.; WU, M.; EHLEN, J. C.; PAUL, K.; GAMBLE, K. L.; JOHNSON R. L.; BESING, R. C.; MENAKER, M.; GEWIRTZ, A. T.; DAVIDSON, A. J. Dysregulation of inflammatory responses by chronic circadian disruption. $\mathbf{J}$. Immunol., v. 185, n. 10, p. 5796-5805, 2010. 
CASTINETTI, F.; CONTE-DEVOLX, B.; BRUE, T. Medical treatment of Cushing's syndrome: glucocorticoid receptor antagonists and mifepristone. Neuroendocrinology, v. 92, n.1, p. 125-130, 2010.

CATO, A. C.; WADE, E. Molecular mechanisms of anti-inflammatory action of glucocorticoids. Bioessays, v. 18, n. 5, p. 371-378, 1996.

CHEAD, C.; CASSEL, M.; BORELLA, M. I.; COSTA, F. G. Morphologic study of the liver of lambari (Astyanax altiparanae) with emphasis on the distribution of cytokeratin. Fish Physiol. Biochem., v. 40, p. 571-576, 2014.

CHEATHAM, B.; KAHN, C. R. Insulin action and the insulin signaling network. Endocr. Rev., v. 16, n. 2, p. 117-142, 1995.

CHERRINGTON, A. D. Control of glucose uptake and release by the liver in vivo. Diabetes, v. 48, p. 1198-1214, 1999.

CHOI, S. H.; GONEN, A.; DIEHL, C. J.; KIM, J.; ALMAZAN, F.; WITZTUM, J. L.; MILLER, Y. I. SYK regulates macrophage MHC-II expression via activation of autophagy in response to oxidized LDL. Autophagy, v. 11, n. 5, p. 785-795, 2015.

CIPOLLA-NETO, J.; BARTOL, I.; SERAPHIM, P. M.; AFECHE, S. C.; SCIALFA, J. H.; PERAÇOLI, A. M. The effects of lesion of thalamic intergeniculate leaflet on the pineal metabolism. Brain Research, v. 691, p.133-145, 1995.

CIPOLLA-NETO, J.; SKOURUPA, A. L.; RIBEIRO-BARBOSA, E. R.; BARTOL, I.; MOTA, S. R.; AFECHE, S. C.; DELAGRANGE, P.; GUARDIOLA-LEMAITRE, B.; CANTERAS, N. S. The role of the retrochiasmatic area on the control of the pineal metabolism. Neuroendocrinology, v. 69, p. 97-104, 1999.

COMPARE, D.; COCCOLI, P.; ROCCO, A.; NARDONE, O. M.; DE MARIA, S.; CARTENI, M.; NARDONE, G. Gut-liver axis: the impact of gut microbiota on non alcoholic fatty liver disease. Nutrition, Metabolism and Cardiovascular Diseases, v. 22, n. 6, p. 471-476, 2012.

CONSIDINE, R. V. A glândula supra-renal. In: RHOADES, R. A.; TANNER, G. A. (Ed.). Fisiologia médica. Rio de Janeiro: Guanabara Koogan, 2005. p. 594- 608.

CONTI, A.; MAESTRONI, G. J. M. The clinical neuroimmunotherapeutic role of melatonin in oncology. J. Pineal Res., v. 19, p. 103-110, 1995.

CORTEZ-PINTO, H.; DE MOURA, M. C.; DAY, C. P. Non-alcoholic steatohepatitis: from cell biology to clinical practice. J. Hepatol., v. 44, n. 1, p. 197-208, 2006. 
COSTES, S.; BOSS, M.; THOMAS, A. P.; MATVEYENKO, A. V. Activation of Melatonin Signaling Promotes $\beta$-Cell Survival and Function. Mol. Endocrinol., v. 29, n. 5, p. 682-692, 2015.

DAHL, G. E.; TAO, S.; THOMPSON, I. M. Lactation Biology Symposium: effects of photoperiod on mammary gland development and lactation. J. Anim. Sci., v. 90, n. 3, p. 755-760, 2012.

DARMAUN, D.; MATTHEWS, D. E.; BIER, D. M. Physiological hypercortisolemia increases proteolysis, glutamine and alanine production. Am. J. Physiol., v. 255, p. 366-373, 1988.

DE MINICIS, S.; RYCHLICKI, C.; AGOSTINELLI, L.; SACCOMANNO, S.; CANDELARESI, C.; TROZZI, L.; MINGARELLI, E.; FACINELLI, B.; MAGI, G.; PALMIERI, C.; MARZIONI, M.; BENEDETTI, A.; SVEGLIATI-BARONI, G. Dysbiosis contributes to fibrogenesis in the course of chronic liver injury in mice. Hepatology, v. 59, n. 5, p. 1738-1749, 2014.

DEFRONZO, R. A. Pathogenesis of type 2 diabetes mellitus: metabolic and molecular implications for identifying diabetes genes. Diabetes Rev., v. 5, p. 117269, 1997.

DEFRONZO, R. A.; FERRANNINI, E.; HENDLER, R.; FELIG, P.; WAHREN, J. Regulation of splanchnic and peripheral glucose uptake by insulin and hyperglycemia. Diabetes, v. 32, p. 35-45, 1983.

DEFRONZO, R. A.; FERRANNINI, E.; SIMONSON, D. C. Fasting hyperglycemia in non-insulin-dependent diabetes mellitus: contributions of excessive hepatic glucose production and impaired tissue glucose uptake. Metabolism, v. 38, p. 387-395, 1989.

DEFRONZO, R. A.; GUNNARSSON, R.; BJORKMAN, O.; OLSSON, M.; WAHREN.J. Effects of insulin on peripheral and splanchnic glucose metabolism in non-insulin dependent diabetes mellitus. J. Clin. Invest., v. 76, p. 149-155, 1985.

DEGENHARDT, T. P.; THORPE, S. R.; BAYNES, J. W. Chemical modification of proteins by methylglyoxal. Cell Mol. Biol., v. 44, n. 7, p. 1139-1145, 1998.

DELAUNAY, F.; KHAN, A.; CINTRA, A.; DAVANI, B.; LING, Z. C.; ANDERSON, A.; OSTENSON C. G.; GUSTAFSSON, J.; EFENDIC, S.; OKRET, S. Pancreatic beta cells are important targets for the diabetogenic effects of glucocorticoids. J. Clin. Invest., v. 100, n. 8, p. 2094-2098, 1997.

DENT, P.; LAVOINNE, A.; NAKIELNY, S. CAUDWELL, F. B.; WATT, P.; COHEN, $P$. The molecular mechanisms by which insulin stimulates glycogen synthesis in mammalian skeletal muscle. Nature, v. 348, p. 302-307, 1990. 
DHANASEKARAN, D. N.; REDDY, E. P. JNK signaling in apoptosis. Oncogene, v. 27, p. $6245-6251,2008$.

DING, Z.; LIU, S.; WANG, X.; KHAIDAKOV, M.; DAI, Y.; DENG, X.; FAN, Y.; XIANG, D.; MEHTA, J. L. Lectin-like ox-LDL receptor-1 (LOX-1)-Toll-like receptor 4 (TLR4) interaction and autophagy in CATH, a differentiated cells exposed to angiotensin II. Mol. Neurobiol., v. 51, n. 2, p. 623-632, 2015.

DU, L.; LYLE, C. S.; OBEY, T. B.; GAARDE, W. A.; MUIR, J. A.; BENNETT, B. L. Inhibition of cell proliferation and cell cycle progression by specific inhibition of basal JNK activity: evidence that mitotic Bcl-2 phosphor- ylation is JNKindependent. J. Biol. Chem., v. 279, p. 11957-11966, 2004.

DU, K.; HERZIG, S.; KULKARNI, R. N.; MONTMINY, M. TRB3: a tribbles homolog that inhibits AKT/PKB activation by insulin in liver. Science, v. 300, n. 5625, p. 1574-1577, 2003.

ENGERMAN, R. L.; KERN, T. S.; LARSON, M. E. Nerve conduction and aldose reductase inhibition during 5 years of diabetes or galactosaemia in dogs. Diabetologia, v. 37, n. 2, p. 141-144, 1994.

EXTON, J. H.; PARK, C. R. Control of gluconeogenesis in liver. Effects of Llactate, pyruvate, fructose, glucagon, epinephrine, and adenosine 3',5'monophosllhate on gluconeogenic intermediates III the perfused rat liver. Biol. Chem., v. 244, p. 1424-1433, 1969.

FERREIRA, D. S.; AMARAL, F. G.; MESQUITA, C. C.; BARBOSA, A. P. L.; LELLIS-SANTOS, C.; TURATI, A. O.; SANTOS, L .R.; SOLLON, C. S. GOMES, P. R.; FARIA, J. A.; CIPOLLA-NETO, J.; BORDIN, S.; ANHÊ, G.F. Maternal melatonin programs the daily pattern of energy metabolism in adult offspring. Plos One, v. 7, n. 6, p. 1-10, 2012.

FERRER, J. C.; FAVRE, C.; GOMIS R. R.; FERNANDEZ-NOVELL, J. M.; GARCIA-ROCHA, M.; DE LA IGLESIA, N.; CID, E.; GUINOVART, J. J. Control of glycogen deposition. FEBS Lett., v. 546, p. 127-132, 2003.

FLESERIU, M.; BILLER, B. M.; FINDLING, J. W.; MOLITCH, M. E.; SCHTEINGART, D. F.; GROSS, C.; SEISMIC Study Investigators. Mifepristone, glucocorticoid receptor antagonist, produces clinical and metabolic benefits in patients with Cushing's syndrome. J. Clin. Endocrinol. Metab., v. 97, n. 6, p. 2039-2049, 2012.

FORBES, J. M.; COOPER, M. E.; OLDFIELD, M. D. THOMAS, M. C. Role of advanced glycation end products in diabetic nephropathy. J. Am. Soc. Nephrol., v. 14 , p. $254-258,2003$. 
FOSTER J. D.; NORDLIE, R. C. The biochemistry and molecular biology of the glucose-6-phosphatase system. Exp. Biol. Med., v. 227, n. 8, p. 601-608, 2002.

FRANCK, N.; MARIS, M.; NALBANDIAN, S.; TALUKDAR, S. SCHENK, S.; HOFMANN, H. P. BULLOUGH, D.; OSBORN, O. Knock-down of IL-1Ra in obese mice decreases liver inflammation and improves insulin sensitivity. PLoS One, v. 9, n. 9, p. e107487, 2014.

FRANSSON, L.; ROSENGREN, V.; SAHA, T. K.; GRANKVIST, N.; ISLAM, T.; HONKANEN, R. E.; SJOHOLM, A.; ORTSATER, H. Mitogen-activated protein kinases and protein phosphatase 5 mediate glucocorticoid-induced cytotoxicity in pancreatic islets and $\beta$-cells. Mol. Cell Endocrinol., v. 383, p. 126-136, 2014.

FULLER, P. M.; GOOLEY, J. J.; SAPER, C. B. Neurobiology of the sleep-wake cycle: sleep architecture, circadian regulation, and regulatory feedback. J. Biol. Rhythms, v. 21, n. 6, p. 482-493, 2006.

GALBO, H.; HOLST, J. J.; CHRISTENSEN, N. J. Glucagon and plasma catecholamine responses to graded and prolonged exercise in man. J. Appl. Physiol., v. 38, p. 70-76, 1975.

GANDA, O. P.; WEIR, G. C.; SOELDNER, J. S.; LEGG, M. A.; CHICK, W. L.; PATEL, Y. C.; EBEID, A. M.; GABBAY, K. H.; REICHLIN, S. "Somatostatinoma": A somatostatin-containing tumor of the endocrine pancreas. N. Engl. J. Med., v. 296, p. 963-967, 1977.

GENUTH, S. M. Supra-renais. In: BERNE, R. M.; LEVY, M. N. (Ed.) Fisiologia. Rio de Janeiro: Guanabara Koogan, 1993. p. 877-909.

GILAD, E.; CUZZOCREA, S.; ZINGARELLI, B.; SALZMAN, A. L.; SZABÓ, C. Melatonin is a scavenger of peroxynitrite. Life Sci., v. 60, p. 169-174, 1997.

GILAD, E.; WONG, H. R.; ZINGARELLI, B.; VIRAG, L.; O'CONNOR, M.; SALZMAN, A. L.; SZABÓ, C. Melatonin inhibits expression of the inducible isoform of nitric oxide synthase in murine macrophages: role of inhibition of NFKappaB activation. FASEB J., v. 12, n. 9, p. 685-693, 1998.

GIROTTI, M.; WEINBERG, M. S.; SPENCER, R. L. Diurnal expression of functional and clock-related genes throughout the rat HPA axis: system-wide shifts in response to a restricted feeding schedule. Am. J. Physiol. Endocrinol. Metab., v. 296 , p. $888-897,2009$.

GLENNON, E.; KAUNZNER, U. W.; GAGNIDZE, K.; MCEWEN, B. S.; BULLOCK, K. Pituitary dendritic cells communicate immune pathogenic signals. Brain Behav. Immun., v. 402-X, n. 15, p. S0889-S1591, 2015. 
GOH, S. Y.; COOPER, M. E. Clinical review: The role of advanced glycation end products in progression and complications of diabetes. J. Clin. Endocrinol. Metab., v. 93, n. 4, p. 1143-1152, 2008.

GOLDIN, A.; BECKMAN, J. A.; SCHMIDT, A. M.; CREAGER, M. A. Advanced glycation end products: sparking the development of diabetic vascular injury. Circulation, v. 114, n. 6, p. 597-605, 2006.

GOMIS, R. R.; FERRER, J. C.; GUINOVART, J. J Shared control of hepatic glycogen synthesis by glycogen synthase and glucokinase. Biochem. J., v. 351, p. 811-816, 2000.

GONZALEZ-HABA, M. G.; GARCIA-MAURIÑO, S.; CALVO, J. R.; GOBERNA, R.; GUERRERO, J. M. High affinity binding of Melatonin by human circulating $T$ lymphocytes (CD4/). FASEB J., v. 9, p. 1331-1335, 1995.

GURURAJAN, M.; CHUI, R.; KARUPPANNAN, A. K.; KE J.; JENNINGS, C. D.; BONDADA, S. c-Jun N-terminal kinase (JNK) is required for survival and proliferation of B-lymphoma cells. Blood, v. 106, p. 1382-1391, 2005.

HARDIE, D. G.; CARLING, D. The AMP-activated protein kinase--fuel gauge of the mammalian cell? Eur. J. Biochem., v. 246, n. 2, p. 259-273, 1997.

HASSID, W. Z.; ABRAHAM, S. Chemical procedures for analysis of polysaccharides. Methods in Enzymology, v. 3, p. 34-50, 1957.

HEIMAN, M. L.; PORTER, J. R. Inhibitory effects of a pineal extract on adrenal cortex. Lack of competition with ACTH. Horm. Res., v. 12, n. 2, p. 104-112, 1980.

HOSTAMISLIGIL, G. S. Inflammation and metabolic disorders. Nature, v. 444, n. 7121, p. 860-867, 2006.

HOSTAMISLIGIL, G. S. Inflammatory pathways and insulin action. Int. J. Obes. Relat. Metab. Disord., v. 27, p. S53-S55, 2003. Suppl 3.

HUNTER, R. W.; TREEBAK, J. T.; WOJTASZEWSKI, J. F; SAKAMOTO, K. Molecular mechanism by which AMP-activated protein kinase activation promotes glycogen accumulation in muscle. Diabetes, v. 60, p. 766-774, 2011.

HUSSAIN, M. M.; SHI, J.; DREIZEN, P. Microsomal triglyceride transfer protein and its role in apoB-lipoprotein assembly. J. Lipid Res., v. 44, p.22-32, 2003.

ISHIDA, Y.; KONDO, T.; KIMURA, A.; MATSUSHIMA, K.; MUKAIDA, N. Absence of IL-1 receptor antagonist impaired wound healing along with aberrant NFkappaB activation and a reciprocal suppression of TGF-beta signal pathway. $\mathbf{J}$. Immunol., v. 176, n. 9, p. 5598-5606, 2006. 
IYNEDJUAN, P. B. Mammalian glucokinase and its gene. Biochem. J., v. 1, n. 293, p. 1-16, 1993.

JAMIESON, P. M.; CHAPMAN, K. E.; SEXKL, J. R. Tissue- and temporal-specific regulation of 11 beta-hydroxysteroid dehydrogenase type 1 by glucocorticoids in vivo. J. Steroid Biochem. Mol. Biol., v. 68, n. 5- 6, p. 245-250, 1999.

JUNQUEIRA, L. C. U.; JUNQUEIRA, L. M. M. S. Técnicas básicas de citologia e histologia. Santos: São Paulo, 1983. 123 p.

KARIN, M.; BEM-NERIAH, Y. Phosphorylation meets ubiquitination: the control of NF-[kappa]B activity. Annu. Ver. Immunol., v. 18, p. 621-663, 2000.

KINOTE, A.; FARIA, J. A.; ROMAN, E. A.; SOLON, C.; RAZOLLI, D. S.; IGNACIOSOUZA, L. M.; SOLLON, C. S.; NASCIMENTO, L. F.; DE ARAUJO, T. M.; BARBOSA, A. P.; LELLIS-SANTOS, C.; VELLOSO, L. A.; BORDIN, S.; ANHÊ, G. $F$. Frutose induced hypotathalamic AMPK activation stimulates hepatic PEPCK and gluconeogenesis due to increseased corticosterona levels. Endocrinology, v. 153, n. 8, p. 3633-3645, 2012.

LACY, P. E.; KOSTIANOVSKY, M. Method for the isolation of intact islets of Langerhans from the rat pancreas. Diabetes, v. 1, p. 35-39, 1967.

LAEMMLI, U. K. Cleavage of structural proteins during the assembly of the head of bacteriophage T4. Nature, v. 227, n. 5259, p. 680-685, 1970.

LANSBERG, L.; YOUNG, J. B. Catecholamines and the adrenal medulla. In: WILSON, J. D.; FOSTER, D. W.; DANIEL, W. (Ed.). Williams textbook of endocrinology. Philadelphia: WB Saunders Company, 1992.

LAU, E.; CARVALHO, D.; FREITAS, P. Gut microbiota: Association with NAFLD and metabolic disturbances. Biomed. Res., v. 2015, 2015. In press.

LAUGERO, K. D. Reinterpretation of basal glucocorticoid feedback: implications to behavioral and metabolic disease. Vitam. Horm., v. 69, p. 1-29, 2004.

LAWRENCE, J. C.; ROACH, P. J. New insights into the role and mechanism of glycogen synthase activation by insulin. Diabetes, v. 46, p. 541-547, 1997.

LE ROY, T.; LLOPIS, M.; LEPAGE, P.; BRUNEAU, A.; RABOT, S.; BEVILACQUA, C.; MARTIN, P.; PHILIPPE, C.; WALKER, F.; BADO, A.; PERLEMUTER, G.; CASSARD-DOULCIER, A. M.; GÉRARD, P. Intestinal microbiota determines development of non-alcoholic fatty liver disease in mice. Gut, v. 62, n. 12, p. 17871794, 2013. 
LETURQUE, A.; BROT-LAROCHE, E.; LE GALL, M. GLUT2 mutations, translocation, and receptor function in diet sugar managing. Am. J. Physiol. Endocrinol. Metab., v. 296, n. 5, p. 985-992, 2009.

LEVENE, A. P.; GOLDIN, R. D. The epidemiology pathogenesis and histopathology of fatty liver disease. Histopathology, v. 61, n. 2, p. 141-152, 2012.

LI, J.; FORHEAD, A. J.; DAUNCEY, M. J.; GLIMOUR, R. S.; FOWDEN, A. L. Control of growth hormone receptor and insulin-like growth factor-1 expression by cortisol in ovine fetal skeletal muscle. Journal of Physiology, v. 541, p. 581-589, 2002.

LI, J.; OWENS J. A.; OWENS P. C.; SAUNDERS, J. C.; FOWDEN, A. L.; GILMOUR, R. S. The ontogeny of hepatic growth hormone receptor and insulinlike growth factor-I gene expression in the sheep fetus during late gestation: developmental regulation by cortisol. Endocrinology, v.137, p. 1650-1657, 1996.

LI, J.; SAUNDERS, J. C.; GILMOUR, R. S.; SILVER, M.; FOWDEN, A. L. Insulinlike growth factor-II messenger ribonucleic acid expression in fetal tissue of the sheep during late gestation: effects of cortisol. Endocrinology, v. 132, p. 20832089, 1993.

LI, J.; SCHMIDT, A. M. Characterization and functional analysis of the promoter of RAGE, the receptor for advanced glycation end products. J. Biol. Chem., v. 272, n. 26, p. 16498-16506, 1997.

LI, M. O.; WAN, Y. Y.; SANJABI, S.; ROBERTSON, A. K.; FLAVELL, R. A. Transforming growth factor-beta regulation of immune responses. Anu. Rev. Immunol., v. 24, p. 99-146, 2006.

LISSONI, P.; BARNI, S.; TANCINI, G.; BRIVIO, F.; TISI, E.; ZUBELEWICZ B.; BRACZKOWSKI B. Role of the pineal gland in the control of macrophage functions and its possible implications in cancer: a study of interactions between tumor necrosis factor alpha. J. Biol. Regul. Homeost. Agents, v. 8, n. 4, p. 126129, 1994.

LISSONI, P.; BARNI, S.; TANCINI, G.; ROVELLI, F.; ARDIZZOIA, A.; CONTI, A.; MAESTRONI, G. J. M. A study of the mechanisms involved in the immunostimulatory action of the pineal hormone in cancer patients. Oncology, v. 50, p. 399-402, 1993.

LISSONI, P.; VIGORE, L.; RESCALDANI, R.; ROVELLI, F.; BRIVIO, F.; GIANI, L.; BARNI, S.; TANCINI, G.; ARDIZZOIA, A.; VIGANO, M. G. Neuroimmunotherapy with low dose subcutaneous interleukin- 2 plus melatonin in AIDS patients with CD4 cell number below 200/mm3: a biological phase-Il study. J. Biol. Regul. Homeost., v. 9, p. 155-158, 1995. 
MAESTRONI, G. J. M. The photoperiod transducer melatonin and the immunehematopoietic system. J. Photochem. Photobiol. B., v. 43, n. 3, p. 186-192, 1998.

MAESTRONI, G. J. M. T-helper-2 lymphocytes as a peripheral target of melatonin. J. Pineal Res., v. 18, n. 2, p. 84- 89, 1995.

MAESTRONI, G. J. M.; CONTI, A.; LISSONI. P. Colony stimulating activity and hematopoietic rescue from cancer chemotherapy compounds are induced by melatonin via endogenous interleukin 4. Cancer Res., v. 54, p. 4740-4743, 1994.

MAESTRONI, G. J. M.; CONTI, A.; PIERPAOLI, W. Role of the pineal gland in immunity: II. Melatonin enhances the antibody response via an opiatergic mechanism. Clin. Exp. Immunol., v. 68, p. 384-390, 1987.

MAGNUSON, M. A.; ANDREONE, R. T.; PRINTZ, R. L.; KOCH, S.; GRANNER, D. K. Rat Glucokinase Gene: Structure and Regulation by Insulin. PNAS, v. 1, n. 86, p. 4838-3842, 1989.

MAKINO, S.; HASHIMOTO, K.; GOLD, P. W. Multiple feedback mechanisms activating corticotrophin-releasing hormone system in the brain during stress. Pharmacol. Biochem. Behav., v. 73, n. 1, p. 147-158, 2002.

MANDARINO, L.; BONADONNA, R.; MCGUINNESS, O.; WASSERMAN, D. Regulation of muscle glucose uptake in vivo. In: JEFFERSON, L. S.; CHERRINGTON, A. D. (Ed.). Handbook of physiology. Oxford: Oxford University Press, 2001. p. 803-848.

MAO, J.; DEMAYO, F. J.; LI, H.; ABU-ELHEIGA, L.; GU, S.; SHAIKENOV, T. E.; KORDARI, P.; CHIRALA, S. S.; HEIRD, W. C.; WAKIL, S. J. Liver-specific deletion of acetyl-CoA carboxylase 1 reduces hepatic triglyceride accumulation without affecting glucose homeostasis. Proc. Natl. Acad. Sci., v. 103, n. 22, p. $8552-$ 8557, 2006.

MAO, J.; REGELSON, W.; KALIMI, M. Molecular mechanism of RU 486 action: a review. Mol. Cell Biochem., v. 109, n. 1, p. 1-8, 1992.

MARIISS, E. B.; AOKI, T. T.; POZEFSKY, T.; MOST, A. S.; CAHILL, G. F. Jr. Muscle and splanchnic glutamine and glutamate metabolism in post-absorptive and prolonged-starved man. J. Clin. Invest., v. 50, n. 8, p. 14-17, 1971.

MARTINS, E. JR.; FERREIRA, A. C.; SKORUPA, A. L. AFECHE, S. C. CIPOLLANETO, J. COSTA ROSA, L. F. Tryptophan consumption and indoleamines production by peritoneal cavity macrophages. J. Leukoc. Biol., v. 75, n. 6, p. 1116-1121, 2004. 
MARTINS, E. JR.; LIGEIRO DE OLIVEIRA, A. P.; FIALHO DE ARAUJO, A. M.; TAVARES DE LIMA, W.; CIPOLLA-NETO, J.; COSTA ROSA, L. F. Melatonin modulates allergic lung inflammation. J. Pineal Res., v. 31, n. 4, p. 363-369, 2001.

MASTORAKOS, G.; CHROUSOS, G. P.; WEBER, J. S. Recombinant interleukin-6 activates the hypothalamic-pituitary-adrenal axis in humans. J. Clin. Endocrinol. Metab., v. 77, n. 6, p. 1690-1694, 1993.

MCGARRY, J. D.; FOSTER, D. W. Hormonal control of ketogenesis. Arch. Int. Med., v. 1, n. 37, p. 495-501, 1977.

MCGARRY, J. D.; WRIGHT, P.; FOSTER, D. W. Hormonal control of ketogenesis: Rapid activation of hepatic ketogenic capacity in fed rats by antiinsulin serum and glucagon. J. Clin. Invest., v. 55, n. 1, p. 202-209, 1975.

MCMAHON, M.; GERICH, J.; RIZZA, P. Effects of glucocorticoids on carbohydrate metabolism. Diabetes/Metabolism Reviews, v. 4, n. 1, p. 17-30, 1988.

MENCIN, A.; KLUWE, J.; SCHWABE, R. F. Toll-like receptors as targets in chronic liver diseases. Gut, v. 58, n. 5, p. 704-720, 2009.

MEVORACH, M.; GIACCA, A.; AHARON, Y.; HAWKINS, M.; SHAMOON, H.; ROSSETTI, L. Regulation of endogenous glucose production by glucose per se is impaired in type 2 diabetes mellitus. J. Clin. Invest., v. 102, p. 744-753, 1998.

MONCADA S.; PALMER, R. M.; HIGGS, E. A. Nitric oxide: physiology, pathophysiology, and pharmacology. Pharmacol. Rev., v. 43, n. 2, p. 109-142, 1991.

MOORE, M. C.; CONNOLLY, C. C.; CHERRINGTON, A. D. Autoregulation of hepatic glucose production. Eur. J. Endocrinol., v. 138, n. 3, p. 240-248, 1998.

NATHAN, C.; XIE, Q. W. Nitric oxide synthases: roles, tolls and controls. Cell, v. 78, p. 915-918, 1994.

NAUGLER, W. E.; KARIN, M. The wolf in sheep's clothing: the role of interleukin-6 in immunity, inflammation and cancer. Trends Mol. Med., v. 14, p. 109-119, 2008.

NELSON, R. J.; DEMAS, G. E. Role of melatoninin mediating seasonal energetic and immunologic adaptations. Brain Res., v. 44, p. 423-430, 1997.

NIKOLAOU, K.; SARRIS, M.; TALIANIDIS, I. Molecular pathways: the complex roles of inflammation pathways in the development and treatment of liver cancer.

Clin. Cancer Res., v. 19, n. 11, p. 2810-2816, 2013. 
NIKOLIC, I.; VUJICIC, M.; SAKSIDA, T.; BERKI, T.; STOSIC-GRUJICIC, S.; STOJANOVIC, I. The role of endogenous glucocorticoids in glucose metabolism and immune status of MIF-deficient mice. Eur. J. Pharmacol., v. 714, p. 498-506, 2013.

NOGUEIRA, T. C.; LELLIS-SANTOS, C.; JESUS, D. S.; TANEDA, M.; RODRIGUES, S. C.; AMARAL, F. G.; LOPES, A. M.; CIPOLLA-NETO, J.; BORDIN, S.; ANHE, G. F. Absence of melatonin induces night-time hepatic insulin resistance and increased gluconeogenesis due to stimulation of nocturnal unfolded protein response. Endocrinology, v. 152, n. 4, p. 1253-1263, 2011.

OECKINGHAUS, A.; HAYDEN, M. S.; GHOSH, S. Crosstalk in NF-kB signaling pathways. Nat. Immunol., v. 12, p. 695-708, 2011.

ORTH, D. N.; KOVACS, W. J. The adrenal cortex. In: WILSON, J. D.; FOSTER, D. W.; KRONEN-BERG, H. M.; LARSEN, P. R. (Ed.). Willians Textbook of endocrinology. Philadelphia: WB Saunders Company, 1998, p. 517-664.

OXENKRUG, G. F.; MCINTYRE, I. M.; GERSHON, S. Effects of pinealectomy and aging on the serum corticosterone circadian rhythm in rats. J. Pineal Res., v. 1, n. 2, p. 181-185, 1984.

PATTON, D. F.; PARFYONOV, M.; GOURMELEN, S.; OPIOL, H.; PAVLOVSKI, I., MARCHANT, E. G.; CHALLET, E.; MISTLBERGER, R. E. Photic and pineal modulation of food anticipatory circadian activity rhythms in rodents. PLoS One, v. 8, n. 12, p. e81588, 2013.

PERRS, S. H.; FLOWER, R. J. The role of lipocortin in corticosteroid actions. Am. Rev. Respir. Dis., v. 141, p. 18-22, 1990.

PESCHKE, E.; BÄHR, I.; MÜHLBAUER, E. Experimental and clinical aspects of melatonin and clock genes in diabetes. J. Pineal Res., v. 59, n. 1, p. 1-23, 2015.

PICINATO, M. C.; HABER, E. P.; CIPOLLA-NETO, J.; CURI, R.; DE OLIVEIRA CARVALHO, C. R.; CARPINELLI, A. R. Melatonin inhibits insulin secretion and decreases PKA levels without interfering with glucose metabolism in rat pancreatic islets. J Pineal Res., v. 33, n. 3, p. 156-160, 2002.

PIERPAOLI, W. Pineal grafting and melatonin induce immunocompetence in nude (athymic) mice. J. Neurosci., v. 68, p. 123-131, 1993.

POWELL, E. E.; COOKSLEY, W. G.; HANSON, R.; SEARLE, J.; HALLIDAY, J. W.; POWELL, L. W. The natural history of nonalcoholic steatohepatitis: a follow-up study of forty-two patients for up to 21 years. Hepatology, v. 11, n. 1, p. 74-80, 1990. 
PROTZEK, A. O. P.; COSTA-JÚNIOR, J. M.; REZENDE, L. F.; SANTOS, G. J.; ARAÚJO, T. G.; VETTORAZZI, J. F.; ORTIS, F.; CARNEIRO, E. M.; RAFACHO, A.; BOSCHERO, A. C. Augmented $\beta$-cell function and mass in glucocorticoidtreated rodents are associated with increased islet IR- $\beta / A K T / m T O R$ and decreased AMPK/ACC and AS160 signaling. Inter. J. Endocrinol., v. 2014, 2014. In press.

RAABE, M.; VENIANT, M. M.; SULLIVAN, M. A.; ZLOT, C. H.; BJORKEFREN, J.; NIELSEN, L. B. WONG, J. S.; HAMILTON, R. L.; YOUNG, S. G. Analysis of the role of microsomal triglyceride transfer protein in the liver of tissue-specific knockout mice. J. Clin. Invest., v. 103, p. 1287-1298, 1999.

RADZIUK, J.; PYE, S. Diurnal rhythm in endogenous glucose production is a major contributor to fasting hyperglycaemia in type 2 diabetes. Suprachiasmatic deficit or limit cycle behaviour? Diabetologia, v. 49, n. 7, p. 1619-1628, 2006.

RAFACHO, A. Effects of glucocorticoids and exercise on pancreatic $\beta$-cell fuction and diabetes development: comments on Beaudry and Riddel. Diabetes Metab. Res. Rev., v. 30, p. 120-121, 2014.

RAFACHO, A.; ORTSATER, H.; NADAL, A.; QUESADA, I. Glucocorticoid treatment and endocrine pâncreas function: implications for glucose homeostasis, insulin resistance and diabetes. Journal of Endocrinology. v. 223, n. 3, p. 49-62, 2014.

RAMADOSS, P.; UNGER- SMITH, N.E.; LAM, F.S.; HOLLENBERG, A.N. STAT3 targets the regulatory regions of gluconeogenic genes in vivo. Mol. Endocrinol., v. 23, n. 6 , p. 827-837, 2009.

REINHARDT, E. L.; FERNANDES, P. A.; MARKUS, R. P.; FISCHER, F. M. Daily rhythm of salivary IL1 $\beta$, cortisol and melatonin in day and night workers. Work, v. 41 , p. 5788-5790, 2012.

REITER, R. J. Functional pleiotropy of the neurohormone melatonin: antioxidant protection and neuroendocrine regulation. Front. Neuroendocrinol., v. 16, p. 383415, 1995a.

REITER, R. J. Oxidative processes and antioxidative defense mechanisms in the aging brain. FASEB J., v. 9, p. 526-533, 1995b.

REITER, R. J. The melatonin rhythm: both a clock and a calendar. Experientia, v. 49, n. 8, p. 654-664, 1993.

REITER, R. J.; GUERRERO, J. M. Melatonin immune system relationships. Curr. Top. Med. Chem., v. 2, p. 167-179, 2002. 
RIBEIRO-BARBOSA, E. R.; SKORUPA, A. L.; CIPOLLA-NETO, J.; CANTERAS, N. S. Projections of the basal retrochiasmatic area: a neural site involved in the photic control of pineal metabolism. Brain Research, v. 839, p. 35-40, 1999.

ROACH, P. J. Glycogen and its metabolism. Curr. Mol. Med., v. 2, p. 101-120, 2002.

RODRIGUES, S. C.; PANTALEÃO, L. C.; NOGUEIRA, T. C.; GOMES, P. R. L.; ALBUQUERQUE, G.; NACHBAR, R.; TORRES-LEAL, F.; CAPERUTO, L.; LELLIS-SANTOS, C.; ANHÊ, G; BORDIN, S. Selective regulation of hepatic lipid metabolism by the AMP-activated protein kinase pathway in late-pregnant rats. J. Physiol. Regul. Integr. Comp. Physiol., v. 307, n. 9, p. 1146-1156, 2014.

RUZZIN, J.; WAGMAN, A. S.; JENSEN, J. Glucocorticoidinduced insulin resistance in skeletalmuscles: defects in insulin signalling and the effects of a selective glycogen synthase kinase- 3 inhibitor. Diabetologia, v. 48, n. 10, p. 2119-2130, 2005.

SALTIEL, A. R.; KAHN, C. R. Insulin signaling and the regulation of glucose and lipid metabolism. Nature, v. 414, p. 799-806, 2001.

SCHACKE, H.; DOCKE, W. D.; ASADULLAH, K. Mechanisms involved in the side effects of glucocorticoids. Pharmacology and Therapeutics, v. 96, n. 1, p. 23-43, 2002.

SCHENK, S.; SABERI, M.; OLEFSKY, J. M. Insulin sensitivity: modulation by nutrients and inflammation. J. Clin. Invest., v. 118, n. 9, p. 2992-3002, 2008.

SCHIEKOFER, S.; ANDRASSY, M.; CHEN, J.; RUDOFSKY, G.; SCHNEIDER, J.; WENDT, T.; STEFAN, N.; HUMPERT, P.; FRITSCHE, A.; STUMVOLL, M.; SCHLEICHER, E.; HARING, H. U.; NAWTOTH, P. P.; BIERHAUS, A. Acute hyperglycemia causes intracellular formation of CML and activation of ras, p42/44 MAPK, and nuclear factor kappaB in PBMCs. Diabetes, v. 52, n. 3, p. 621-633, 2003.

SCHLEIMER, R. P. Effects of glucocorticosteroids on inflammatory cells relevant to their therapeutic applications in asthma. Am. Rev. Respir. Dis., v. 141, p. 5969, 1990.

SCHMIDT, A. M.; STERN, D. M. RAGE: a new target for the prevention and treatment of the vascular and inflammatory complications of diabetes. Trends Endocrinol. Metab., v. 11, n. 9, p. 368-375, 2000.

SCHWABE, R. F.; BRENNER, D. A. Mechanisms of Liver Injury. I. TNF-alphainduced liver injury: role of IKK, JNK, and ROS pathways. Am. J. Physiol. Gastrointest. Liver Physiol., v. 290, n. 4, p. 583-589, 2006. 
SCOTT, E. M.; GRANT, P. J. Neel revisited: the adipocyte, seasonality and type 2 diabetes. Diabetologia, v. 49, n. 7, p. 1462-1466, 2006.

SENESI, S.; CSALA, M.; MARCOLONGO, P.; FULCERI, R.; MANDL, J.; BANHEGYI, G.; BENEDETTI, A. Hexose-6-phosphate dehydrogenase in the endoplasmic reticulum. Biol. Chem., v. 39, n. 1, p. 1-8, 2010.

SIDDIQI, S.; MANI, A. M.; SIDDIQI, S. A. The identification of the SNARE complex required for the fusion of VLDL-transport vesicle with hepatic cis-Golgi. Biochem. J., v. 429, n. 2, p. 391-401, 2010.

SPENCER, M. D.; HAMP, T. J.; REID, R. W.; FISCHER, L. M.; ZEISEL, S. H.; FODOR, A. A. Association between composition of the human gastrointestinal microbiome and development of fatty liver with choline deficiency. Gastroenterology, v. 140, n. 3, p. 976-986, 2011.

SUGARMAN, B. J.; AGGARWAL, B. B.; HASS, P. E.; FIGARI, I. S.; PALLADINO, M. A.; SHEPARD, H. M. Recombinant human tumor necrosis factor-alpha: effects on proliferation of normal and transformed cells in vitro. Science, v. 230, n. 4728, p. 943-945, 1985.

SZABÓ, C. Alterations in nitric oxide production in various forms of circulatory shock. New Horiz., v. 3, n. 1, p. 2-32, 1995.

SZANTO, A.; ROSZER, T. Nuclear receptors in macrophages: a link between metabolism and inflammation. FEBS Lett., v. 582, n. 1, p. 106-116, 2008.

TARANTINO, G.; SALDALAMACCHIA, G.; CONCA, P.; ARENA, A. Nonalcoholic fatty liver disease: further expression of the metabolic syndrome. $\mathbf{J}$. Gastroenterol. Hepatol., v. 22, n. 3, p. 293-303, 2007.

TERRÓN, M. P.; DELGADO-ADÁMEZ, J.; PAREDES, S. D.; RODRÍGUEZ, A. B. Melatonin reduces body weight gain and increases nocturnal activity in male Wistar rats. Physiology Behavior, v. 13, n. 118, p. 8-13, 2013.

THAKUR, S.; BAYDOUN, A. R. Post-transcriptional divergence in the regulation of CAT-2A, CAT-2B and iNOS expression by dexamethasone in vascular smooth muscle cells. Amino Acids, v. 43, n. 2, p. 667-676, 2012.

THROCKMORTON, D. C.; BROGDEN, A. P.; MIN, B.; RASMUSSEN, H.; KASHGARIAN, M. PDGF and TGF-beta mediate collagen production by mesangial cells exposed to advanced glycosylation end products. Kidney Int., v. 48, n. 1, p. 111-117, 1995.

TILG, H.; MOSCHEN, A. R. Evolution of inflammation in nonalcoholic fatty liver disease: the multiple parallel hits hypothesis. Hepatology, v. 52, n. 5, p. 18361846, 2010. 
TOMLINSON, J. W.; WALKER, E. A.; BUJALSKA, I. J.; DRAPER, N.; LAVERY, G. G.; COOPER, M. S.; HEWISON, M.; STEWART, P. M. 11beta-hydroxysteroid dehydrogenase type 1: a tissue-specific regulator of glucocorticoid response. Endocrine Reviews, v. 25, n. 5, p. 831-866, 2004.

TSUKUMO, D. M.; CARVALHO-FILHO, M. A. CARVALHEIRA, J. B.; PRADA, P. O.; HIRABARA, S. M. SCHENKA, A. A.; ARAÚJO, E. P.; VASSALLO, J.; CURI, R. VELLOSO, L. A.; SAAD, M. J. Loss-of-function mutation in Toll-like receptor 4 prevents diet-induced obesity and insulin resistance. Diabetes, v. 56, n. 8, p. 1986-1998, 2007.

UMEKI, S.; SOEJIMA, R. Hydrocortisone inhibits the respiratory burst oxidase from human neutrophils in whole-cell and cell-free systems. Biochim. Biophys. Acta, v. 1052, n. 1, p. 211-215, 1990.

UNGER, R. H.; DOBBS, R. E.; ORCI, L. Insulin, glucagon and somatostatin secretion in the regulation of metabolism. Annu. Rev. Physiol., v. 40, p. 307-343, 1978.

UYEDA, K.; YAMASHITA, H.; KAWAGUCHI, T. Carbohydrate responsive element-binding protein (ChREBP): a key regulator of glucose metabolism and fat storage. Biochem. Pharmacol., v. 63, n. 12, p. 2075-2080, 2002.

VEGIOPOULOS, A.; HERZIG, S. Glucocorticoids, metabolism and metabolic diseases. Mol. Cell. Endocrinol., v. 275, p. 43-61, 2007.

VLASSARA, H. Advanced glycosylation in nephropathy of diabetes and aging. Adv. Nephrol. Necker Hosp., v. 25, p. 303-315, 1996.

VRANIC, M.; KAWAMORI, R.; PEK, S.; KOVACEVIC, N.; WRENSHALL, G. A. The essentiality of insulin and the role of glucagon in regulating glucose utilization and production during strenuous exercise in dogs. J. Clin. Invest., v. 57, p. 245255, 1976.

VRANIC, M.; KAWAMORI, R.; WRENSHALL, G. A. Mechanism of exercise induced hypoglycemia in depancreatized insulin-treated dogs. Diabetes, v. 23, p. 353, 1974. Suppl.

VRANIC, M.; WRENSHALL, G. A. Exercise, insulin, and glucose turnover in dogs. Endocrinology, v. 8, n. 5, p. 165-167, 1969.

WAJANT, H.; PFIZENMAIER, K.; SCHEURICH, P. Tumor necrosis factor signaling. Cell Death Differ., v. 10, n. 1, p. 45-65, 2003.

WEITZMAN, E. D.; FUKUSHIMA, D.; NOGEIRE, C.; ROFFWARG, H.; GALLAGHER, T. F.; HELLMAN, L. Twenty-four hour pattern of the episodic 
secretion of cortisol in normal subjects. J. Clin. Endocrinol. Metab., v. 33, p. 1422, 1971.

WEST, A. P.; KOBLANSKY, A. A.; GHOSH, S. Recognition and signaling by tolllike receptors. Annu. Rev. Cell Dev. Biol., v. 22, p. 409-437, 2006.

WETTERAU, J. R.; LIN, M. C.; JAMIL, H. Microsomal triglyceride transfer protein. Biochim. Biophys. Acta., v. 1345, p. 136-150, 1997.

YAO, X. H.; NYOMBA, B. L. Hepatic insulin resistance induced by prenatal alcohol exposure is associated with reduced PTEN and TRB3 acetylation in adult rat offspring. Am. J. Physiol. Regul. Integr. Comp. Physiol., v. 294, n. 6, p. 1797806, 2008.

YUEBIN, G. E.; YAN, Z.; RUI, L.; WEI, C.; YANG, L.; GUOXUN, C. Berberine Regulated Gck, G6pc, Pck1 and Srebp-1c Expression and Acti-vated AMPactivated Protein Kinase in Primary Rat Hepatocytes. International Journal of Biological Sciences, v. 7, n. 5, p. 673-684, 2011.

ZHANG, W.; PATIL, S.; CHAUHAN, B.; GUO, S.; POWELL, D. R.; LE, J.; KLOTSAS, A.; MATIKA, R.; XIAO, X.; FRANKS, R.; HEIDENREICH, K. A.; SAJAN, M. P.; FARESE, R. V.; STOLZ, D. B.; TSO, P.; KOO, S. H.; MONTMINY, M.; UNTERMAN, T. G. FoxO1 regulates multiple metabolic pathways in the liver: effects on gluconeogenic, glycolytic, and lipogenic gene expression. J. Biol. Chem., v. 281, n. 15, p. 10105-10117, 2006.

ZHAO, J. P.; BAO, J.; WANG, W. J.; JIAO, H. C.; SONG, Z. G.; LIN, H. Altered gene and protein expression of glucose transporter 1 underlies dexamethasone inhibition of insulin-stimulated glucose uptake in chicken muscles. J. Anim. Sci., v. 90, n. 12, p. 4337-4345, 2012. 